Universidade de São Paulo

Faculdade de Medicina de Ribeirão Preto

Departamento de Clínica Médica

Envolvimento das Aurora-quinases e DIDO na instabilidade cromossômica na leucemia linfoide crônica

Felipe Canto de Souza

Ribeirão Preto

2016 


\section{Envolvimento das Aurora-quinases e DIDO na instabilidade cromossômica na leucemia linfoide crônica}

Dissertação apresentada ao Programa de Pós-Graduação em Oncologia Clínica, Células Tronco e Terapia Celular da Faculdade de Medicina de Ribeirão Preto da Universidade de São Paulo, como parte dos pré-requisitos para obtenção do título de Mestre em Ciências.

Área de concentração: Diferenciação Celular Normal e Neoplásica

Orientador: Dr. Rodrigo Alexandre Panepucci

"Versão corrigida. A versão original encontra-se disponível tanto na Biblioteca da Unidade que aloja o Programa, quanto na Biblioteca Digital de Teses e Dissertações da USP (BDTD)".

\section{Ribeirão Preto}


AUTORIZO A REPRODUÇÃO E DIVULGAÇÃO TOTAL OU PARCIAL DESTE TRABALHO, POR QUALQUER MEIO CONVENCIONAL OU ELETRÔNICO, PARA FINS DE ESTUDO E PESQUISA, DESDE QUE CITADA A FONTE.

\section{FICHA CATALOGRÁFICA}

Souza, Felipe Canto de
Envolvimento das Aurora-quinases e DIDo na instabilidade
cromossômica na leucemia linfoide crônica
Ribeirão Preto, 2016.
Dissertação de Mestrado, apresentada à Faculdade de
Medicina de Ribeirão Preto/USP. Área de concentração:
Diferenciação Celular Normal e Neoplásica.
Orientador: Panepucci, Rodrigo Alexandre.
1. Aurora-quinase. 2. DIDO. 3. Instabilidade Cromossômica. 4.
E2F1. 5. cluster miR-17 92.


FOLHA DE APROVAÇÃO

Felipe Canto de Souza

Envolvimento das Aurora-quinases e DIDO na instabilidade cromossômica na leucemia linfoide crônica

Dissertação apresentada à Faculdade de Medicina de Ribeirão Preto da Universidade de São Paulo para obtenção do título de Mestre em Ciências.

Área de concentração: Diferenciação Celular Normal e Neoplásica

Aprovado em:

\section{Banca examinadora:}

Prof. Dr. Rodrigo Alexandre Panepucci

Instituição

Assinatura

Prof. Dr.

Instituição

Assinatura

Prof. Dr.

Instituição

Assinatura 


\section{DEDICATÓRIA}

À minha família, pelo apoío incondicional, e às amizades construídas, fundamentais para a realização deste trabalho. 


\section{AGRADECIMENTOS}

Ao meu orientador, Prof. Rodrigo Alexandre Panepucci, por ter concedido a oportunidade de trabalhar ao seu lado e me tornar Mestre alcançado um importante degrau no desenvolvimento da carreira científica.

Aos meus pais, Ricardo e Azair, por me incentivarem e me apoiarem sempre.

À minha namorada Camila pelo companheirismo, amizade, amor, por ter me apoiado em todos os momentos.

À Dra. Josiane Lilian dos Santos Schiavinato, pela dedicação em inúmeros ensinamentos compartilhados, participação e auxílio no desenvolvimento de todas as pesquisas do grupo.

À todos os meus amigos do laboratório de Hematologia (Josiane, Bruno, Vitor, Ildercílio, Sarah, Helder, Hudson, Igor, Mariane, Danuta e Lara) pela amizade, pelas valiosas conversas e por terem compartilhado inúmeros ensinamentos em todos os momentos desta jornada.

Às técnicas do Laboratório de Hematologia e Biologia Molecular I, Amélia, Claúdia, Bete e Júlia, que sempre estiveram dispostas a me auxiliar, seja na preparação de materiais, no esclarecimento de dúvidas ou, ainda, em questões particulares. Muito obrigado pelo apoio, amizade e carinho!

Aos meus amigos do Departamento de Bioquímica (Diego, Sarah, Deisy, Larissa, Ligia, Dimitrius, Andre, Andrea, Paulo e a técnica Lucia) pela amizade e apoio nas atividades relacionadas à análise de proteínas, assim como, ao Professor Claudio Miguel da Costa Neto, por ter compartilhado seus ensinamentos e permitido uma parceria com ganho de conhecimento entre laboratórios.

À Priscila e a Aglair, especialistas em citometria de fluxo, sem as quais não poderia ter realizado inúmeras análises no decorrer deste trabalho.

À toda a equipe da Secretaria de Pós-Graduação em Oncologia Clínica, Células Tronco e Terapia Celular, em especial a Adriana, pela pronta disponibilidade.

À FAPESP, CNPq, FAEPA e INCTC pelo auxílio financeiro concedido. 


\section{RESUMO}

SOUZA, F. C. Envolvimento das Aurora-quinases e DIDO na instabilidade cromossômica na leucemia linfoide crônica. Dissertação de Mestrado - Faculdade de Medicina de Ribeirão Preto, Universidade de São Paulo, Ribeirão Preto, 2016.

Durante a divisão celular as Aurora-quinases (AURKA e AURKB) participam da formação e controle das fibras do fuso mitótico enquanto as isoformas proteicas (DIDO1, DIDO2 e DIDO3), originadas do splicing alternativo do gene DIDO, auxiliam na junção dos microtúbulos aos cinetócoros. Portanto, ambas são relevantes na regulação do ciclo celular. Interessantemente, a superexpressão (ou o ganho de função) das AURKs ou a baixa expressão (ou perda de função) das isoformas de DIDO estão ambos associados com amplificação dos centrossomos e à instabilidade cromossômica (CIN), com consequente aneuploidia. Dentre as doenças hematológicas com registros de CIN, a leucemia linfoide crônica (LLC) pode apresentar amplificação dos centrossomos e alteração nos níveis de expressão das AURKs acarretando aneuplodias. Apesar disso, não existem estudos avaliando a potencial associação destes genes com CIN na LLC. Avaliando seus níveis de expressão gênica em amostras de LLC de pacientes com ou sem aberrações cromossômicas, mostramos que o aumento dos níveis de AURKA e AURKB e, inversamente, a redução dos níveis das variantes de DIDO, são significativamente associados com ganhos cromossômicos e com aumento da contagem de glóbulos brancos (WBC). Claramente, amostras de LLC sem qualquer anormalidade citogenética apresentam níveis de expressão semelhantes às amostras que contêm aberrações não-numéricas. $O$ achado de que níveis de expressão de AURKs e variantes de DIDO são completamente opostos, mostrando um padrão discreto de inter-relação, levou-nos a investigar o potencial mecanismo regulatório por trás disso. Tendo em vista que outros, anteriormente, mostraram que o cluster oncogênico miR-17 92 é significativamente hiper-regulado em células de pacientes com LLC purificadas expressando genes IGHV não mutados (em comparação com células mutadas de pacientes) e, que o miR-17 é expresso em níveis significativamente mais elevados em células IGHV não mutadas ou ZAP-70 positivas (mau prognóstico geralmente associada à $\mathrm{CIN}$ ), resolvemos investigar o potencial de 
regulação negativa dos microRNAs deste cluster sobre as variantes de DIDO. Além disso, com base no mecanismo regulatório já descrito pelo qual a superexpressão de AURKA induz a transcrição do cluster miR-17 92, mediada por E2F1 (com uma correlação entre as expressões de ambas as proteínas em diferentes tipos de câncer), decidimos investigar este eixo regulatório em LLC. Notavelmente, todas as variantes de DIDO apresentam-se preditas como fortes alvos de vários microRNAs deste cluster oncogênico. Mostramos, então, que amostras de LLC com baixa expressão de DIDO, além dos já mencionados níveis elevados de AURK, exibiram níveis significativamente mais elevados do fator de transcrição E2F1 e de seu alvo transcricional, o transcrito primário do miR-17 92 (MIR17HG). Além disso, por meio do uso da linhagem de celular NTERA-2, como modelo experimental, mostramos que o siRNA nocaute para AURKA (nos níveis transcricional e proteico, como confirmado por qPCR e western blot) é acompanhada por uma significativa redução de E2F1 e também de MIR17HG. Ainda, a transfecção de células NTERA-2 com sintéticos microRNAs miméticos do cluster miR-17 92 (ou seja, 19a-miR, miR-20a e miR-92a) resultou em uma clara e significativa redução dos níveis de transcrição de todas as variantes de DIDO. Por fim, a inibição do siRNA especifico para a variante DIDO3 (mas não às outras variantes) levou a uma redução significativa dos níveis de transcrição de todas as variantes de DIDO, indicando um mecanismo adicional contribuindo para a downregulação dos transcritos de DIDO. Ao todo, nossos resultados demonstram a existência de um potencial mecanismo regulatório interconectado entre AURK e DIDO, associado à CIN e maior contagem de WBC na LLC. Mais importante, os níveis de expressão elevada de AURKs e os baixos níveis associados das variantes de DIDO são especificamente relacionados com anormalidades citogenéticas apresentando ganhos cromossomais, com destaque para o mecanismo celular específico, subjacente à $\mathrm{CIN}$, observado neste grupo distinto LLC. Dado o papel central da CIN na gênese e progressão do câncer, esses achados provavelmente terão um impacto importante no prognóstico ou tratamento da LLC.

Palavras-chave: Aurora-quinase; DIDO; instabilidade cromossômica; E2F1; cluster miR-17 92. 


\section{ABSTRACT}

SOUZA, F. C. SOUZA, F. C. Involvement of Aurora kinases and DIDO in chromosomal instability in chronic lymphoid leukemia. Dissertação de Mestrado Faculdade de Medicina de Ribeirão Preto, Universidade de São Paulo, Ribeirão Preto, 2016.

During cell cycle division Aurora kinases (AURKA and AURKB) participate in the formation and control of mitotic spindle fibers, while, protein isoforms (DIDO1, DIDO2 and DIDO3), derived by alternative splicing of the DIDO gene, assist at the junction of microtubules to kinetochores. Thus, both are relevant to cell cycle maintenance. Interestingly, overexpression (or gain of function) of AURKs or low expression (or loss of function of DIDO) are both associated with centrosomal amplification and chromosomal instability (CIN), leading to aneuploidy. Among hematological diseases with CIN records, chronic lymphocytic leukemia (CLL) can display centrosome amplification and changes in AURKs expression levels leading to aneuploidy. Despite this, there are no studies evaluating the potential association of these genes with CIN in CLL. By evaluating their gene expression levels in CLL samples from patients with or without chromosomal aberrations, we show that increased levels of AURKA and AURKB and, conversely, reduced levels of DIDO variants, are both significantly associated with chromosomal gains and with increased white blood cell (WBC) counts. Clearly, CLL samples without any cytogenetic abnormality had expression levels similar to samples mostly harboring non-numerical aberrations. The finding that the expression levels of AURKs and DIDO variants are completely opposed, showing a discrete inter-related pattern, led us to investigate the potential regulatory mechanism behind this. Given that other have previously shown that the oncogenic miR-17 92 cluster is significantly upregulated in purified CLL patient cells expressing unmutated IGHV genes (as compared to mutated patient cells), and that miR-17 is expressed at significantly higher levels in unmutated or ZAP-70 high cases (bad prognostic cases generally associated with chromosomal instability), we investigated the potential negative regulation of DIDO variants by microRNAs from this cluster. In addition, based on the already described regulatory mechanism by which AURKA overexpression induces the E2F1-mediated transcription upregulation of the miR-17 92 cluster (with an 
observed expression correlation of both proteins in cancer specimens); we decided to investigate this regulatory axis in CLL. Notably, we found that all DIDO variants are predicted to be heavily targeted by several miRs of this oncogenic cluster. We show that CLL samples with low DIDO expression, in addition to the already mentioned AURK high levels, displayed significant higher levels of the transcription factor E2F1 and of its transcriptional target, the miR-17 92 primary transcript (MIR17HG). Moreover, by using the NTERA-2 cell line as a model, we show that siRNA knockdown of AURKA (at the transcript and protein level, as confirmed by qPCR and western blot) is accompanied by a striking significant reduction of E2F1 and also of MIR17HG. Furthermore, transfection of NTERA-2 cells with synthetic mimics of the miR-17 92 cluster (namely, miR-19a, miR-20a and miR-92a) results in a clear and significant reduction in the transcript levels of all DIDO variants. Finally, specific siRNA inhibition of the DIDO3 variant (but not the others) led to a significant reduction in the transcript levels of all DIDO variants, indicating an additional mechanism contributing to the downregulation of DIDO transcripts. Altogether, our results demonstrate the existence of a potential interconnected regulatory mechanism between AURK and DIDO, associated with CIN and higher WBC counts in CLL. More importantly, the high expression levels of AURKs and the associated low levels of DIDO variants are specifically associated with cytogenetic abnormalities presenting chromosomal gains, highlighting the specific cellular mechanism underlying the CIN observed in this distinct CLL group. Given the central role of CIN in cancer genesis and progression, these findings will likely have an important impact on prognosis or treatment of CLL.

Keywords: Aurora kinase; DIDO; chromosomal instability; E2F1; cluster miR17 92. 


\section{SUMÁRIO}

1. INTRODUÇÃO

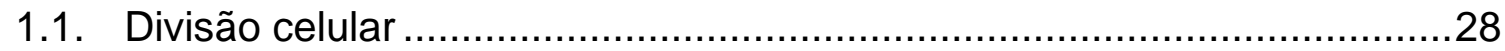

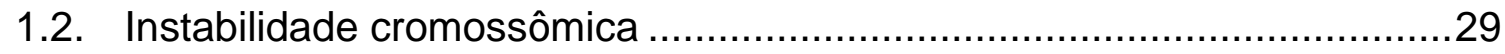

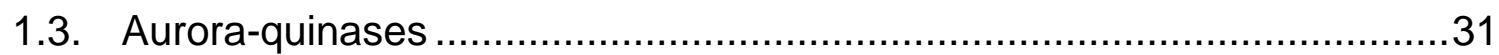

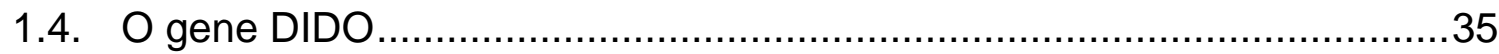

1.5. Instabilidade cromossômica e alterações hematológicas ...........................39

1.6. microRNAs e doenças hematológicas ................................................42

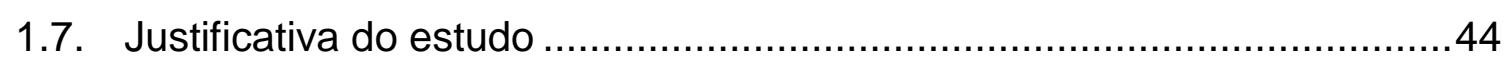

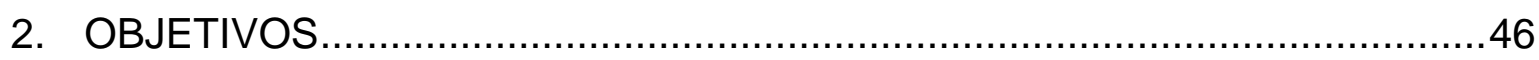

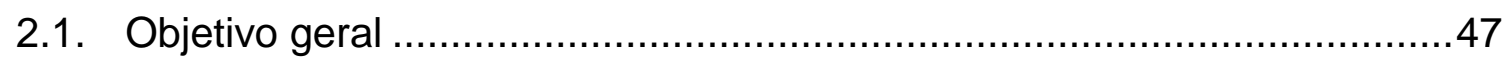

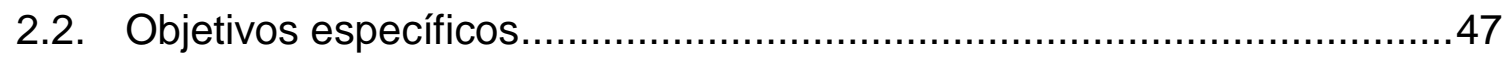

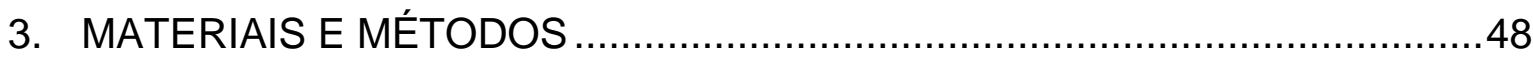

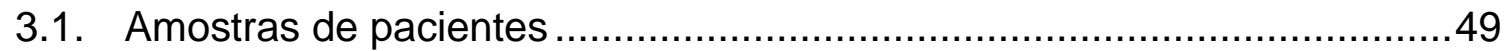

3.2. Caracterização da estrutura gênica do locus DIDO e desenho dos primers para quantificação de suas variantes e demais transcritos

3.3. Desenho e aquisição dos siRNAs para knockdown específico das variantes de DIDO e das AURKs. .50

3.4. Caracterização dos sítios alvo de microRNAs na Região 3'-UTR dos

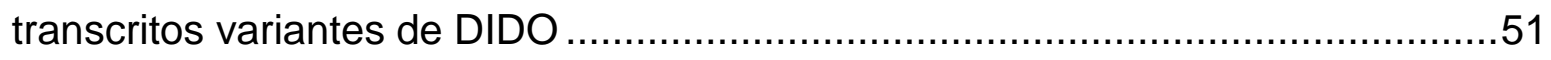

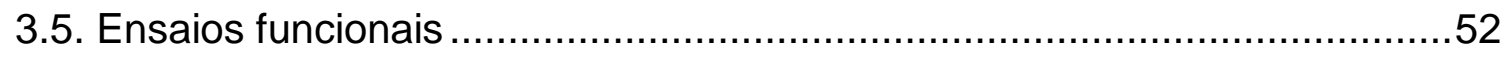

3.5.1. Linhagem celular e condições de cultivo............................................................52

3.5.2. Transfecção dos siRNAs/miRNAs em NTERA-2 ………………………….......52

3.6. Análise da expressão gênica ………………….....................................53

3.6.1. Coleta das células, extração e quantificação do RNA …...................................53

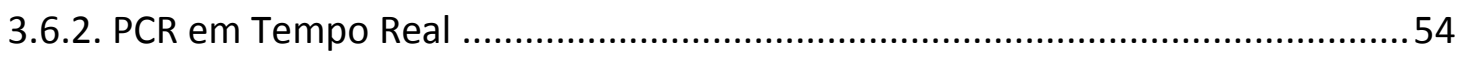

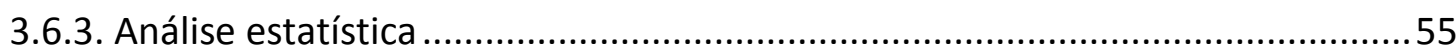




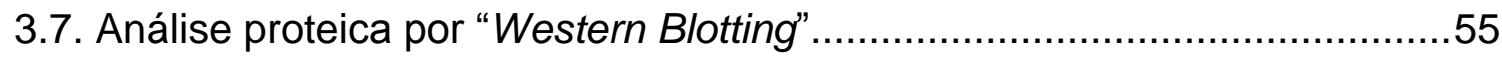

3.7.1. Extração e quantificação das proteínas ..............................................................55

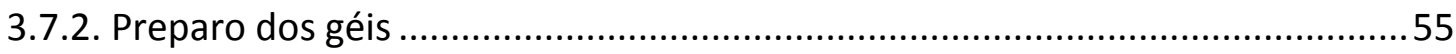

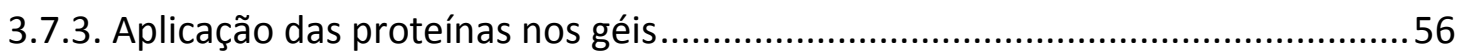

3.7.4. Transferência para membrana de nitrocelulose ................................................57

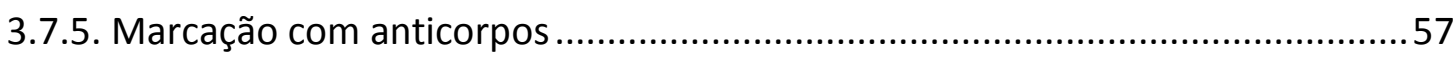

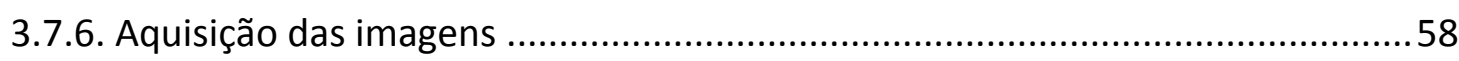

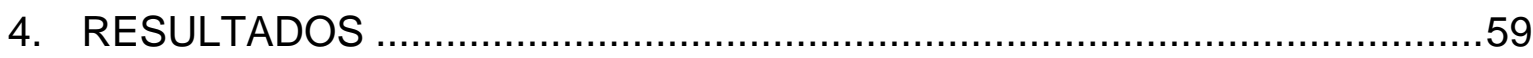

4.1. Estrutura gênica do locus DIDO e de suas variantes .............................60

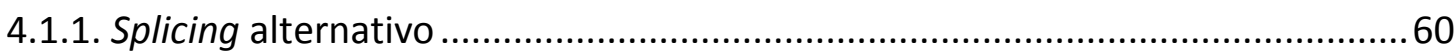

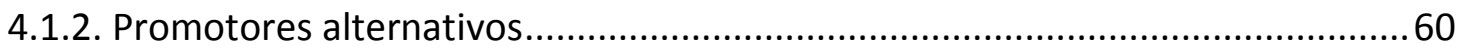

4.1.3. O gene GID8

4.1.4. Identificação de sítios alvos dos microRNAs na 3'-UTR das variantes de DIDO 61

4.2. Expressão de DIDO em amostras de doenças hematológicas 62

4.3. Expressão diferencial de DIDO em amostras de pacientes com LLC ......66

4.4. Expressão de AURKs em amostras de doenças hematológicas .................69

4.5. Análise comparativa entre variantes transcricionais de DIDO e AURKs, em amostras de pacientes com LLC aberrante .71

4.6. Análise comparativa de E2F1, MIR17HG e variantes transcricionais de DIDO, em amostras de pacientes com LLC aberrante........................................73

4.7. Regulação de E2F1, MIR17HG e variantes de DIDO via AURKA ...............75

4.8. Regulação das variantes de DIDO via cluster miR-17 92 ….....................81

4.9. Análise das expressões proteicas de AURKA e isoformas de DIDO, em

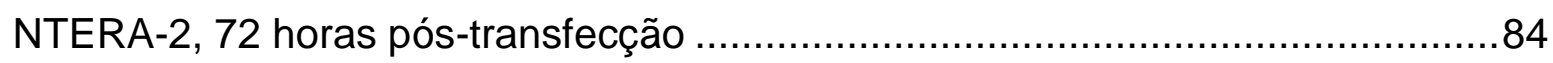

4.10. Silenciamento das isoformas de DIDO por siRNAs específicos ...............87

5. DISCUSSÃO

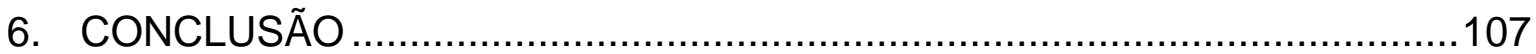




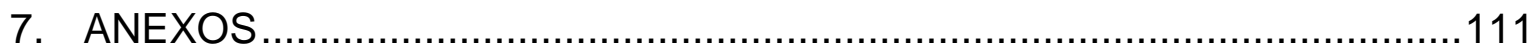

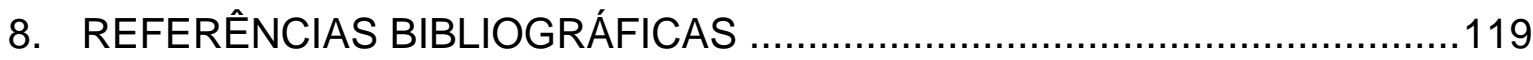




\section{LISTA DE TABELAS}

Tabela 1. Variantes transcricionais de DIDO ........................................49

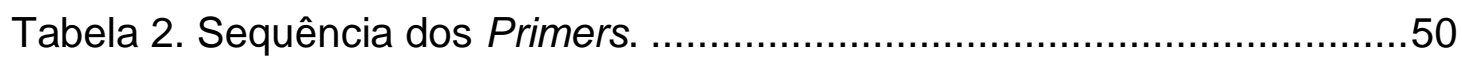

Tabela 3. Sequência dos siRNAs .................................................. 51

Tabela 4. Sequência dos miRNAs ................................................. 52

Tabela 5. Amostras de Pacientes com SMD ...................................... 115

Tabela 6. Amostras de Pacientes com LLC .......................................117 


\section{LISTA DE FIGURAS}

Figura 1. Ligações fibras do fuso - cinetocoro. Erros de ligação microtúbulos - cinetócoro. A correta segregação cromossômica ocorre nas ligações anfitélicas. Cinetócoros sem ligação ou com ligações monotélicas emitem um sinal de checkpoint mitótico. Ligações merotélicas não apresentam estabilidade tensional entre as fibras oriundas de extremidades opostas. Ligações sintélicas tencionam as fibras do fuso para um mesmo polo. Adaptado de (RICKE; VAN DEURSEN, 2011).

Figura 2. Estrutura e domínios das Aurora-quinases. As porções n-terminal e c-terminal das Aurora-quinases contêm domínios com atividade regulatória (d-box e ken) enquanto que a porção central contribui com a atividade catalítica. A porção central possui, também, domínios regulatórios como a alça de ativação, região de autofosforilação proteica (GOLDENSON; CRISPINO, 2015) 32

Figura 3. Aurora-quinase A (AURKA) no ciclo celular. A AURKA se acumula nos centrossomos na fase $S$ e sofre ativação entre as fases $G 2$ e M. A AURKA ativa se propaga pelos microtúbulos do fuso mitótico até a região central. A inativação e degradação de grande quantidade proteica ocorre até o início da citocinese, sendo detectáveis baixos níveis de AURKA já no início de G1 (adaptado de Nikonova et al., 2013)

Figura 4. Isoformas codificadas pelo locus DIDO (DIDO1, DIDO2 e DIDO3). Em listrado, fragmentos específicos das isoformas na porção c-terminal. As cores cinza claro, cinza escuro e preto representam, respectivamente, regiões comuns as três isoformas, regiões comuns à DIDO2 e DIDO3 e, região específica de DIDO3. As setas apontam para localização aproximada dos domínios funcionais de DIDO (NLS, nuclear localization signal; PHD, plant homeodomain; TFIISM, transcription factor s domain ii module; SPOC, spen paralog and ortholog c-terminal domain) e a numeração representa os aminoácidos a partir da porção $\mathrm{N}$-terminal (adaptado de Fütterer et al., 2012). .36

Figura 5. Modelo de translocação de DIDO3 da cromatina para fibras do fuso. A fosforilação das Treoninas 3 e 6 , na Histona 3, desestabiliza a interação do 
domínio $\mathrm{PHD} / \mathrm{K} 4 \mathrm{Me} 3$ promovendo o deslocamento de DIDO3, do núcleo para o citoplasma, via fibras do fuso. (extraído de Gatchalian et al., 2013).

Figura 6. Representação esquemática da biogênese e atuação do miRNA. Cada miRNA é transcrito por meio da RNA polimerase II (pri-miRNA) no núcleo celular. O pri-miRNA é reconhecido pelo complexo enzimático Drosha-DGCR8 e processado em pre-miRNA, o qual é exportado para o citoplasma via exportina 5 (XPO5), sofrendo novo processamento e clivagem pelo complexo DICER gerando duas fitas de miRNAs (miRNA*-miRNA). Apenas uma das fitas de miRNA é incorporada ao complexo RISC. O grau de homologia do miRNA maduro à sequência 3' UTR do mRNA alvo irá determinar a repressão da tradução ou degradação deste; extraído e adaptado de (BERTOLI; CAVA; CASTIGLIONI, 2015).

FIGURA 7. Posição e organização gênica do locus DIDO e suas variantes. As sequências de referência (RefSeqs, NM_) originadas do locus do gene DIDO foram identificadas no site do NCBI e alinhadas ao genoma utilizando a ferramenta online BLAT (UCSC Genome Browser). As três variantes DIDO1, DIDO2 e DIDO3, originadas por splicing alternativo, podem ser transcritas a partir de dois promotores alternativos, um distal (v1, v3 e v4 para DIDO 1, 2 e 3, respectivamente) e um proximal (v2, v6 e v5 para DIDO 1, 2 e 3, respectivamente).

Figura 8. Compartilhamento do promotor distal de DIDO com o transcrito GID8. A inspeção do locus de DIDO levou à identificação do gene GID8 o qual compartilha a mesma região promotora das variantes distais de DIDO. Para clareza, apenas as variantes DIDO1 transcritas a partir de ambos os promotores (distal e proximal) são mostradas. As ilhas CpG são mostradas na figura para ilustrar a presença destes elementos regulatórios nos promotores compartilhados distal e proximal. Figura gerada usando a ferramenta online BLAT (UCSC Genome Browser).

Figura 9. Sítios alvos preditos dos microrRNAs do cluster 17 92 na região 3`UTR das variantes de DIDO. Os identificadores RefSeq dos três transcritos alternativos de DIDO foram utilizados para uma busca no banco de dados online (microrna.org). A posição relativa de cada microRNA foi utilizada para gerar um 
esquema dos sítios de interesse. O esquema do cluster mir-17 92 aparece no topo à esquerda.

Figura 10. Alinhamento dos amplicons esperados com os primers de qPCR desenhados. Os amplicons (esperados para os primers de qPCR desenhados para quantificar as variantes de DIDO1, 2 e 3, assim como GID8, estão indicados na figura, seguidos do tamanho esperado em pares de bases. As sequências dos mesmos foram alinhadas com as sequências de referência (RefSeqs, NM_) originadas do locus do gene DIDO utilizando a ferramenta online Blat (UCSC Genome Browser). As três variantes DIDO1, DIDO2 e DIDO3, originadas por splicing alternativo, podem ser transcritas a partir de dois promotores alternativos, um distal ( $P D$, comum às variantes $\mathrm{v} 1, \mathrm{v} 3$ e v4 para DIDO 1, 2 e 3, respectivamente) e um proximal ( $P P$, comum às variantes v2, v6 e v5 para DIDO 1, 2 e 3, respectivamente).

Figura 11. qPCR dos transcritos de DIDO e GID8 avaliados em amostras de pacientes com doenças hematológicas. Níveis transcricionais de todas as variantes de DIDO determinadas por qPCR. Valores no eixo y correspondem a diferença entre o $\mathrm{Ct}$ do transcrito e o $\mathrm{Ct}$ obtido pelo gene controle GAPDH. O eixo y apresenta-se invertido para melhor compreensão, ou seja, com os menores valores de $\Delta \mathrm{Ct}$ correspondendo aos maiores valores de expressão. MO (Medula Óssea); SP (Sangue Periférico); SMD_Norm (síndrome mielodisplásica com cariótipo normal); SMD_Aberr (síndrome mielodisplásica com cariótipo alterado); LLC_Norm (LLC) (leucemia linfoide crônica com cariótipo normal); LLC_Aberr (LLC) (leucemia linfoide crônica com cariótipo alterado). ${ }^{*} 0.01<p<0.05 ;{ }^{* *} 0.001<p<0.01 ;{ }^{* * *} p<0.001$.

Figura 12. Associação entre níveis de DIDO e características clínicolaboratoriais. As amostras de LLC com alterações cromossômicas foram separadas com base nos níveis de DIDO e comparadas quanto à contagem de células brancas do sangue (WBC) e do número total de cromossomos, na análise do cariótipo. * $0.01<p<0.05 ;{ }^{* *} 0.001<p<0.01 ;{ }^{* * *} p<0.001$ .68

Figura 13. Expressão de AURKA e AURKB em amostras de pacientes com doenças hematológicas e análise comparativa do número de cromossomos e WBC 
entre grupos de LLC aberrante (LLC_Aberr) que expressam níveis elevados ou baixos de AURKs. Altos níveis de expressão de AURKs estão associados à instabilidade cromossômica. Níveis transcricionais das AURKs determinados por qPCR. ${ }^{*} 0.01<p<0.05 ;{ }^{* *} 0.001<p<0.01 ;{ }^{* *} p<0.001$

Figura 14. Análise comparativa da expressão de AURKA e AURKB entre grupos de LLC aberrante (LLC_Aberr) que expressam níveis elevados ou baixos de DIDO. Níveis transcricionais das AURKs determinados por qPCR. Baixos níveis de expressão de DIDO estão associados a um pior prognóstico, assim como a maior propensão à aneuploidias e altas taxas de WBC. Da mesma forma, altos níveis de AURKs estão associados à instabilidade cromossômica. * $0.01<\mathrm{p}<0.05 ;{ }^{* *} 0.001<$ $\mathrm{p}<0.01 ;{ }^{* * *} \mathrm{p}<0.001$ .72

Figura 15. Análise comparativa da expressão de E2F1 e MIR17HG entre grupos de LLC aberrante (LLC_Aberr) que expressam níveis elevados ou baixos de DIDO. Baixos níveis de expressão de DIDO estão associados a um pior prognóstico. Níveis transcricionais de E2F1 e MIR17HG determinados por qPCR. Valores no eixo y correspondem a diferença entre o $\mathrm{Ct}$ do transcrito e o Ct obtido pelo gene controle GAPDH. O eixo y apresenta-se invertido para melhor compreensão, ou seja, com os menores valores de $\triangle \mathrm{Ct}$ correspondendo aos maiores valores de expressão. $\mathrm{A}$ relação inversa entre os níveis de DIDO e das AURKs se faz presente, também, nas análises de expressão relativa de E2F1 e MIR17HG para as três variantes transcricionais de DIDO. * $0.01<p<0.05 ;{ }^{* *} 0.001<p<0.01 ;{ }^{* * *} p<0.001$

Figura 16. Avaliação funcional da eficiência de transfecção de células NTERA-2. Um siRNA contra GAPDH foi transfectado em células NTERA-2 e a redução dos níveis do mRNA (em relação às células transfectadas com um siRNA controle) foi avaliada 72 horas após. Grupos transfectados, em triplicata experimental. A expressão de $\beta$-Actina foi utilizada para a normalização $(\Delta \mathrm{Ct})$. * $0.01<p<0.05 ;{ }^{* *} 0.001<p<0.01 ;{ }^{* * *} p<0.001$

Figura 17. Silenciamento de AURKA por siRNA em células NTERA-2, 72 horas e 120 horas pós-transfecção. Grupos transfectados, em triplicata experimental, de siRNAs contra mRNAs de AURKA. Expressão de AURKA 
normalizada pela expressão de $\beta$-Actina $(\Delta \mathrm{Ct})$ em relação às células transfectadas com o siRNA controle $\left(2--^{\Delta \Delta C t}\right) .{ }^{*} 0.01<p<0.05 ;{ }^{* *} 0.001<p<0.01 ;{ }^{* \star *} p<0.001 . .76$

Figura 18. Efeito do silenciamento de AURKA sobre os níveis de E2F1. Os níveis dos transcritos de E2F1 foram avaliados 72 horas e 120 horas póstransfecção em NTERA-2 com siRNAs contra AURKA. Grupos transfectados, em triplicata experimental. E2F1 normalizado com a expressão de $\beta$-Actina $(\Delta \mathrm{Ct})$. * $0.01<p<0.05 ;{ }^{* *} 0.001<p<0.01 ;{ }^{* * *} p<0.001$

Figura 19. Efeito do silenciamento de AURKA sobre os níveis de MIR17HG. Os níveis dos transcritos de E2F1 foram avaliados 72 horas e 120 horas póstransfecção em NTERA-2 com siRNAs contra AURKA. Grupos transfectados, em triplicata. MIR17HG normalizado pela expressão de $\beta$-Actina $(\Delta \mathrm{Ct}) .{ }^{*} 0.01<p<0.05$; ${ }^{* *} 0.001<p<0.01 ;{ }^{* * *} p<0.001$. 78

Figura 20. Expressão dos transcritos de DIDO1 72 horas e 120 horas póstransfecção em NTERA-2 com siRNAs alvos de AURKA. Grupos transfectados, em triplicata experimental, de siRNAs contra mRNAs de AURKA. DIDO1 normalizado com a expressão de $\beta$-Actina $(\Delta \mathrm{Ct}) .{ }^{*} 0.01<\mathrm{p}<0.05 ;{ }^{* *} 0.001<\mathrm{p}<0.01 ;{ }^{* * *} \mathrm{p}<$ 0.001 79

Figura 21. Expressão dos transcritos de DIDO2 72 horas e 120 horas póstransfecção em NTERA-2 com siRNAs alvos de AURKA. Grupos transfectados, em triplicata experimental, de siRNAs contra mRNAs de AURKA. DIDO2 normalizado com a expressão de $\beta$-Actina $(\Delta \mathrm{Ct}) .{ }^{*} 0.01<\mathrm{p}<0.05 ;{ }^{* *} 0.001<\mathrm{p}<0.01 ;{ }^{* * *} \mathrm{p}<$ 0.001 . .79

Figura 22. Expressão dos transcritos de DIDO3 72 horas e 120 horas póstransfecção em NTERA-2 com siRNAs alvos de AURKA. Grupos transfectados, em triplicata experimental, de siRNAs contra mRNAs de AURKA. DIDO3 normalizado com a expressão de $\beta$-Actina $(\Delta \mathrm{Ct}) .{ }^{*} 0.01<\mathrm{p}<0.05 ;{ }^{* *} 0.001<\mathrm{p}<0.01 ;{ }^{* * *} \mathrm{p}<$ 0.001 . .80

Figura 23. Expressão dos transcritos de GID8 72 horas e 120 horas póstransfecção em NTERA-2 com siRNAs alvos de AURKA. Grupos transfectados, em 
triplicata experimental, de siRNAs contra mRNAs de AURKA. GID8 normalizado com a expressão de $\beta$-Actina $(\Delta \mathrm{Ct})$. ${ }^{*} 0.01<p<0.05 ;{ }^{* *} 0.001<p<0.01 ;{ }^{* *} p<0.001 .81$

Figura 24. Efeito de miRNAs do cluster miR-17 92 sobre DIDO1. Expressão relativa obtida por qPCR, 72 horas e 120 horas pós-transfecção de células NTERA-2 com miRNAs miméticos do cluster miR-17 92. DIDO1 normalizado com a expressão de $\beta$-Actina $(\Delta \mathrm{Ct}) .{ }^{*} 0.01<\mathrm{p}<0.05 ;{ }^{* *} 0.001<\mathrm{p}<0.01 ;{ }^{* *} \mathrm{p}<0.001$

Figura 25. Efeito de miRNAs do cluster miR-17 92 sobre DIDO2. Expressão relativa obtida por qPCR, 72 horas e 120 horas pós-transfecção de células NTERA-2 com miRNAs miméticos do cluster miR-17 92. DIDO2 normalizado com a expressão de $\beta$-Actina $(\Delta \mathrm{Ct}) .{ }^{*} 0.01<\mathrm{p}<0.05 ;{ }^{* *} 0.001<\mathrm{p}<0.01 ;{ }^{* * *} \mathrm{p}<0.001$

Figura 26. Efeito de miRNAs do cluster miR-17 92 sobre DIDO3. Expressão relativa obtida por qPCR, 72 horas e 120 horas pós-transfecção de células NTERA-2 com miRNAs miméticos do cluster miR-17 92. DIDO3 normalizado com a expressão de $\beta$-Actina $(\Delta \mathrm{Ct}) .{ }^{*} 0.01<\mathrm{p}<0.05 ;{ }^{* *} 0.001<\mathrm{p}<0.01 ;{ }^{* *} \mathrm{p}<0.001$

Figura 27. Silenciamento protéico de AURKA em células NTERA-2. Gráfico representativo da expressão proteica observada em células NTERA-2 72 horas póstransfecção com siRNA contra AURKA ou siRNA controle. a) Imagem obtida do gel por Western Blotting utilizando anticorpo contra AURKA e contra $\beta$-Actina. b) Quantificação da imagem demonstrando a redução nos níveis da proteína AURKA, pós-silenciamento, em relação ao ás células transfectadas com o siRNA controle. Os valores foram normalizados pelos níveis endógenos de $\beta$-Actina

Figura 28. Efeito do silenciamento do mRNA AURKA e das variantes transcricionais de DIDO sobre a expressão proteica das isoformas DIDO1 e DIDO2, em NTERA-2, 72 horas pós-transfecção. a) Imagem comparativa das isoformas proteicas DIDO1 e DIDO2, em relação ao endógeno $\beta$-Actina, pós-silenciamento das variantes transcricionais de DIDO e do mRNA AURKA. b) Gráfico representativo da expressão proteica diferencial entre os grupos tratados com siRNA AURKA, siRNA DIDO e grupos tratados com siRNA controle. Os valores foram normalizados com a expressão do endógeno $\beta$-Actina .86 
Figura 29. Efeito dos miRNAs do cluster miR-17 92 sobre os níveis proteicos das isoformas DIDO1 e DIDO2. Células NTera-2 foram transfectadas com miRNAs miméticos pertencentes ao cluster miR-17 92 e o efeito sobre os níveis proteicos das isoformas de DIDO foram determinados por Western Blotting. a) Imagem obtida do gel utilizando anticorpo contra as isoformas de DIDO e contra o controle endógeno $\beta$-Actina, 72 horas pós-transfecção com miRNAs miméticos pertencentes ao cluster miR-17 92. b) Gráfico ilustrando a quantificação relativa das isoformas DIDO1 e DIDO2 nas amostras tratadas com diferentes miRNAs do cluster miR17 92, em relação aos grupos tratados com miRNAs controle. Os valores foram normalizados pelos níveis de expressão da $\beta$-Actina..

Figura 30. Alinhamento dos siRNAs específicos contra regiões 3'-UTR específicas das variantes de DIDO. Para claridade, apenas as variantes transcritas a partir do promotor proximal de DIDO estão apresentadas. Imagem adquirida por meio da plataforma digital BLAT (UCSC Genome Browser).

Figura 31. Avaliação de efeitos inespecíficos dos siRNAs utilizados, sobre a expressão do gene endógeno GAPDH. A linhagem NTERA-2 foi transfectada com os diferentes siRNAs, tendo os níveis do transcrito de GAPDH avaliado após 3 e 5 dias. Os grupos foram transfectados em quadruplicata experimental. Os níveis de GAPDH foram quantificados e normalizado pela expressão de $\beta$-Actina $(\Delta \mathrm{Ct})$. A média dos valores de $\Delta \mathrm{Ct}$ obtidos para o grupo transfectado com o siRNA controle (sem alvo em humano) foi utilizado como valor de referência para cálculo de expressão relativa (2- $\Delta \Delta \mathrm{Ct})$. A figura mostra a eficiência da transfecção e do silenciamento do GAPDH pelo siRNA contra GAPDH, além de uma aparente indução inesperada nos níveis de GAPDH, pelo siDIDO3-52. * $0.01<p<0.05$; ** $0.001<p<0.01 ;{ }^{* * *} p<0.001$.

Figura 32. Expressão da variante transcricional DIDO1 72 horas e 120 horas pós-transfecção, em NTERA-2, com siRNAs alvo específicos. Grupos transfectados, em triplicata experimental, de controles negativo e positivo de silenciamento, assim como de siRNAs exclusivos de cada variante transcricional de DIDO. DIDO1 normalizado com a expressão de $\beta$-Actina $(\Delta \mathrm{Ct}) .{ }^{*} 0.01<\mathrm{p}<0.05 ;{ }^{* *} 0.001<\mathrm{p}<$ $0.01 ;{ }^{* * *} p<0.001$. .90 
Figura 33. Expressão da variante transcricional DIDO2 72 horas e 120 horas pós-transfecção, em NTERA-2, com siRNAs alvo específicos. Grupos transfectados, em triplicata experimental, de controles negativo e positivo de silenciamento, assim como de siRNAs exclusivos de cada variante transcricional de DIDO. DIDO2 normalizado com a expressão de $\beta$-Actina $(\Delta \mathrm{Ct})$. ${ }^{*} 0.01<\mathrm{p}<0.05$; ${ }^{* *} 0.001<\mathrm{p}<$ $0.01 ;{ }^{* *} p<0.001$.

Figura 34. Expressão da variante transcricional DIDO3 72 horas e 120 horas pós-transfecção, em NTERA-2, com siRNAs alvo específicos. Grupos transfectados, em triplicata experimental, de controles negativo e positivo de silenciamento, assim como de siRNAs exclusivos de cada variante transcricional de DIDO. DIDO3 normalizado com a expressão de $\beta$-Actina $(\Delta \mathrm{Ct})$.

Figura 35. Proposta de via regulatória entre AURKA e DIDO. Mecanismo regulatório sobre as variantes de DIDO ocorrendo downstream aos microRNAs do cluster miR-17 92, os quais são regulados indiretamente por meio de níveis de expressão de AURKA. 110

Figura 36. Inibição inespecífica de DIDO1 por siRNAs supostamente específicos contra as outras variantes. Os resultados representam os níveis do mRNA de DIDO1 48 horas após a transfecção da linhagem BJ de fibroblastos com siRNAs contra diferentes variantes de DIDO. a) Expressão de DIDO1 póstransfecção com siDIDO1; b) Expressão de DIDO1 pós-transfecção com siDIDO2; c) Expressão de DIDO1 pós-transfecção com siDIDO3. Grupos transfectados, em triplicata. Os valores foram normalizados pela expressão de GAPDH $(\Delta \mathrm{Ct})$. A expressão relativa das amostras foi calculada utilizando a expressão média do grupo siCtr2 como referência $(2-\Delta \Delta \mathrm{Ct})$. 112

Figura 37. Sequências dos siRNAs compartilhados com as variantes transcricionais de DIDO em exons inespecíficos. 113

FIGURA 38. Contagem do número total de cromossomos, na análise do cariótipo, comparadas quanto aos grupos de SMD aberrante (SMD_Aberr) que expressam níveis elevados ou baixos dos transcritos estudados. A variação dos níveis de expressão de tais transcritos sobre as amostras de SMD aberrante não teve interferência sobre o número de cromossomos. 114 


\section{LISTA DE ABREVIATURAS E SIGLAS}

- $\mu g$ : micrograma

- $\mu \mathrm{L}$ : microlitro

- $\mu \mathrm{M}:$ micromolar

- nm: nanômetro

- nM: nanomolar

- aa: aminoácido

- AKT: do inglês "Protein kinase B"

- APC/C: Complexo Promotor da Anáfase/ Ciclossoma

- APS: do inglês "Ammonium persulfate"

- ATM: do inglês "Ataxia Telangiectasia-Mutated"

- AURKA: Aurora-quinase A

- AURKB: Aurora-quinase $B$

- AURKC: Aurora-quinase $C$

- BCR: do inglês " $B$-cell antigen receptor"

- BRCA1/2: do inglês "Breast cancer type 1/2 susceptibility proteins"

- B/F/B: do inglês "Breakage - Fusion - Bridge"

- BIRC3: do inglês "Baculoviral IAP repeat-containing protein 3"

- BSA: do inglês "Bovine Serum Albumin"

- BTK: do inglês "Tyrosine-protein kinase BTK"

- BUB3: do inglês "Mitotic checkpoint protein BUB3"

- BUBR1: do inglês "Mitotic checkpoint serine/threonine-protein kinase BUB1 beta"

- BYE1: do inglês "Bypass of Ess1"

- CD: do inglês "Cluster of Differentiation"

- CDC20: do inglês "Cell division cycle protein 20 homolog"

- CIN: Instabilidade Cromossômica

- Ct: do inglês "Cycle Threshould"

- CTLH: do inglês "C-terminal to LisH motif"

- DEPC: do inglês "Diethylpyrocarbonate"

- del: deleção 
- DIDO: do inglês "Death-Inducer Obliterator"

- DMEM: do inglês "Dulbecco's Modified Eagle's Medium"

- DNA: Ácido Desoxirribonucleico

- ERK: do inglês "Extracellular signal-Regulated Kinases"

- ESC: do inglês "Embrionic Stem Cell"

- E2F1: Fator de Transcrição E2F1

- FISH: do inglês "Fluorescence in Situ Hybridization"

- GAPDH: do inglês "Glyceraldehyde-3-phosphate dehydrogenase"

- GID8: do inglês "Glucose-induced degradation protein 8 homolog"

- G1/S/G2/M: do inglês "Gap1/ Synthesis/ Gap2/ Mitosis"

- HATs: Histonas Acetil Transferases

- HDACs: Histonas Deacetilases

- H3K4Me3: do inglês "Histone 3 lysine 4 trimethylation"

- IGHV: do inglês "Immunoglobulin Variable Heavy-chain"

- IL-7: do inglês "Interleukin - 7"

- ING2: do inglês "Inhibitor of growth 2"

- KRAS: do inglês "Kirsten Rat Sarcoma viral oncogene homolog"

- LisH: do inglês "Lis homology domain"

- LLC: Leucemia Linfoide Crônica

- LMA: Leucemia Mieloide Aguda

- MAD2: do inglês "Mitotic Arrest Deficient 2"

- MAPK: do inglês "Mitogen-activated protein kinase"

- MEF: do inglês "Mouse Embrionic Fibroblast"

- MLL: do inglês "Mixed Lineage Leukemia"

- MO: Medula Óssea

- mono: monossomia

- miR: microRNA

- miRNA: microRNA

- mRNA: RNA mensageiro

- NaF: Fluoreto de sódio

- NOTCH1: do inglês "Neurogenic locus notch homolog protein 1"

- ORF: do inglês "Open Reading Frame" 
- $\mathrm{p}$ : Braço curto do cromossomo

- PBS: do inglês "Phosphate Buffered Saline"

- PCR: do inglês "Polimerase Chain Reaction"

- PD: Promotor Distal

- PHD: do inglês "Plant Homeodomain"

- PHF3: do inglês "PHD Finger Protein 3"

- PLK: do inglês "Polo-Like kinase"

- PI3K: Fosfatidilinositol-3-quinase

- POLII: RNA Polimerase II

- POLIII: RNA Polimerase III

- POT1: do inglês "Protection of telomeres protein 1"

- PP: Promotor Proximal

- PXDN: do inglês "Peroxidasin homolog"

- q: Braço longo do cromossomo

- qPCR: do inglês "Quantitative Polimerase Chain Reaction"

- RAF: do inglês "RAF proto-oncogene serine/threonine-protein kinase"

- RANBPM: do inglês "Ran-binding protein 9"

- RAS: do inglês "Rat Sarcoma"

- RefSeq: Sequências de Referência

- RISC: do inglês "RNA-induced silencing complex"

- RNA: Ácido Ribonucleico

- RNAi: do inglês "RNA interference"

- SAC: do inglês "Spindle-Assembly Checkpoint"

- SBF: Soro Bovino Fetal

- SDS: do inglês "Sodium Dodecyl Sulfate"

- SCC1: do inglês "Sister chromatid cohesion protein 1"

- SF3B1: do inglês "Splicing factor 3B subunit 1"

- SHARP: do inglês "SMRT/HDAC1-associated repressor protein"

- siRNA: do inglês "short interfering RNA"

- SMD: Síndrome Mielodisplásica

- SMRT/NCoR: do inglês "Silencing mediator for retinoid and thyroid receptors/Nuclear receptor corepressor" 
- SOS: do inglês "Son of sevenless"

- SP: Sangue Periférico

- SPOC: do inglês "Spen paralog and ortholog C-terminal domain"

- TBST: do inglês "Tris-buffered saline, 0.1\% Tween 20"

- TCL1: do inglês "T-cell leukemia/lymphoma 1"

- TEMED: do inglês " $N, N, N$ ', N'-Tetramethylethylenediamine"

- TFIISM: do inglês "Transcription Factor S-IIM"

- TLD: do inglês "TFIIS-like domain"

- TLR9: do inglês "Toll-like Receptor - 9"

- TPX2: do inglês "Targeting Protein for Xklp2"

- TP53: do inglês "Cellular tumor antigen p53"

- tri: trissomia

- TRIS: do inglês "Tris Hydroxymethil aminomethane"

- UTR: do inglês "Untranslated Region"

- WBC: do inglês "White Blood Cell"

- XPO1: Exportina-1

- XPO5: Exportina-5

- ZAP-70: do inglês "70-kDa zeta-associated protein" 


\subsection{Divisão celular}

Durante o ciclo celular normal, dois centrossomos (cada um composto por dois centríolos) funcionam como polos do fuso da célula em divisão. O ciclo de duplicação do centrossomo é coordenado de forma precisa com a progressão do ciclo celular e está intimamente relacionado à replicação do DNA, mitose e citocinese, por meio de vias paralelas de regulação. A presença de apenas dois centrossomos na célula, quando esta entra em mitose, favorece a formação de um fuso bipolar e a separação uniforme dos cromossomos para cada célula filha (CHAN, 2011).

Visando garantir a correta segregação cromossômica, microtúbulos provenientes dos polos opostos do fuso ligam-se, cada qual, a uma das cromátides irmãs, alinhando os cromossomos na placa metafásica. A junção entre microtúbulos e cromossomos ocorre por meio de complexos proteicos, denominados cinetócoros, presentes na região do centrômero. A correta segregação cromossômica é regulada por um mecanismo conhecido como ponto de checagem do fuso mitótico (SAC, Spindle-Assembly Checkpoint), que monitora a fixação dos microtúbulos oriundos de polos opostos do fuso aos cinetócoros das cromátides-irmãs, retardando o início da anáfase até que todos os cromossomos estejam adequadamente ligados (RICKE; VAN DEURSEN, 2011).

Mais precisamente, a ligação bipolar estável dos cinetócoros (amphitelic attachment) leva à dissociação de MAD e BUB, da família de proteínas associadas aos cinetócoros. Caso um centrômero não esteja ligado aos microtúbulos ou se não houver uma tensão adequada entre eles, as proteínas responsáveis pelo SAC emitem um sinal de espera na anáfase, que se difunde para o citoplasma. Este sinal é mediado por complexos contendo as proteínas BUB3, BUBR1 e MAD2, que se ligam e inibem $C D C 20$, sendo este um coativador do complexo promotor da anáfase (APC/C) que marca substratos alvo para degradação pelo proteasoma (TAYLOR; SCOTT; HOLLAND, 2004).

O alinhamento correto de todos os cromossomos mitóticos na placa metafásica inativa o SAC, ativando a $\mathrm{APC} / \mathrm{C}$ e provocando a ubiquitinização e destruição da proteína Securina, inibidora da protease Separase, levando à clivagem 
da subunidade SCC1 do complexo proteico Coesina (que une as cromátides), permitindo a sua separação. Adicionalmente, outros reguladores da mitose (incluindo a ciclina B1) também são ubiquitinizados por APC/C, sendo destruídos, o que leva à transição da metáfase para a anáfase (YU, 2002).

\subsection{Instabilidade cromossômica}

A manutenção da estabilidade genômica e da viabilidade celular dependem de uma complexa e precisa regulação temporal e espacial, que garante a separação coordenada e uniforme das cromátides, durante a divisão celular (HEGYI; MEHES, 2012). Falhas em diferentes pontos de controle da divisão celular (por níveis ou atividade alterada de determinadas proteínas) podem levar ao surgimento de alterações cromossômicas, incluindo aneuploidias e translocações, caracterizando um estado de Instabilidade Cromossômica (CIN). A CIN pode decorrer de defeitos e alterações em diversos pontos de controle ou componentes do ciclo celular, como coesão dos cromossomos, pontos de checagem na montagem do fuso mitótico (SAC), número de cópias do centrossomo, ligação entre cinetócoro e microtúbulos, e regulação do ciclo celular (CHAN, 2011).

Associada ao mecanismo de controle da instabilidade cromossômica, a separação dos cromossomos durante a mitose requer a ligação apropriada dos cinetócoros aos microtúbulos oriundos dos centrossomos.

As ligações microtúbulo-cinetócoro podem, todavia, gerar muitas falhas caso ocorram de forma imprecisa, acarretando aneuploidias. A ligação de microtúbulos de um mesmo polo a apenas um cinetócoro, de uma das cromátides irmãs, denominada ligação monotélica, pode não segregar corretamente os cromossomos na anáfase. Da mesma forma, quando ambos os cinetócoros apresentam-se unidos por microtúbulos de um mesmo polo esta ligação é denominada sintélica e pode gerar uma segregação cromossômica inadequada para as células filhas (CIMINI, 2008). Ainda, a ligação relativamente comum de microtúbulos de polos opostos a um único cinetócoro, denominada merotélica, caso não corrigida no início da mitose gera estresse físico ao centrômero durante a anáfase, podendo causar quebras cromossômicas (GUERRERO; GAMERO; et al., 2010; GUERRERO; MARTINEZ; 
VAN WELY, 2010) (Figura 1). Tais fatores podem ativar, por consequência, o checkpoint mitótico (VAZQUEZ-NOVELLE et al., 2010).

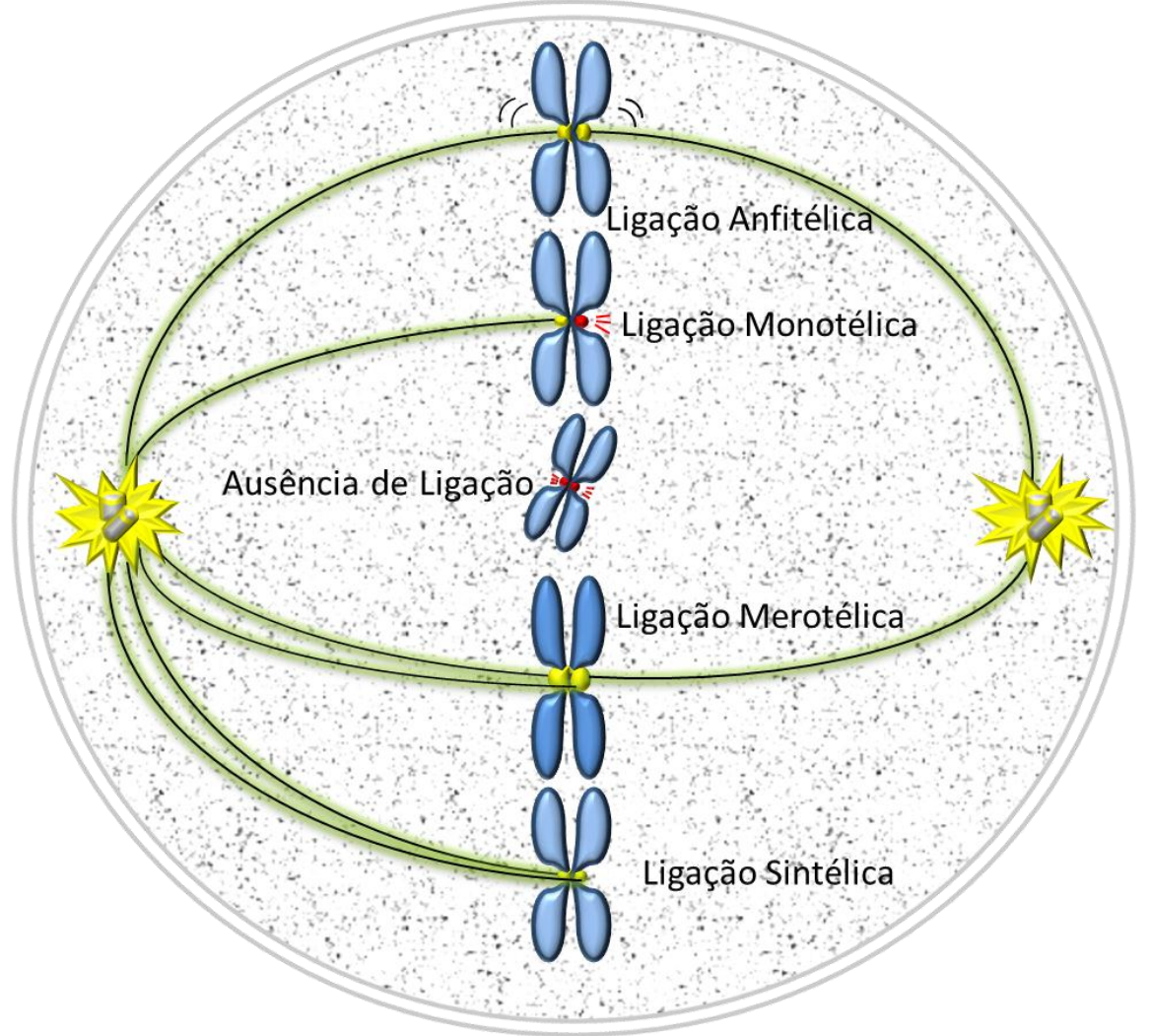

FIGURA 1. Ligações fibras do fuso - cinetócoro. Erros de ligação microtúbulos - cinetócoro. $A$ correta segregação cromossômica ocorre nas ligações anfitélicas. Cinetócoros sem ligação ou com ligações monotélicas emitem um sinal de checkpoint mitótico. Ligações merotélicas não apresentam estabilidade tensional entre as fibras oriundas de extremidades opostas. Ligações sintélicas tencionam as fibras do fuso para um mesmo polo. Adaptado de (RICKE; VAN DEURSEN, 2011).

Outros fatores que propiciam a instabilidade cromossômica dependem da atividade dos telômeros, os quais quando encurtados por eventuais alterações, tanto de sua enzima precursora (telomerase) como de seu complexo proteico (shelterin), proporcionam um ciclo de replicação cromossômica conhecido como Breakage Fusion - Bridge (B/F/B) resultando em aberrações, como deleções, inversões, translocações e possivelmente aneuploidias ao longo de diversas divisões celulares (MURAKI et al., 2012; MURNANE, 2012).

A instabilidade cromossômica é considerada um importante fator na progressão tumoral, contribuindo para o surgimento de uma população heterogênea 
de células tumorais aneuploides que podem apresentar vantagens adaptativas durante o processo evolutivo tumoral, contribuindo para a metástase e a resistência a terapias (BAKHOUM; COMPTON, 2012). De fato, o controle do fuso mitótico é desregulado na maioria dos carcinomas, resultando em um circuito que leva ao acúmulo de alterações e aumento progressivo da instabilidade cromossômica (GUERRERO; GAMERO; et al., 2010; GUERRERO; MARTINEZ; et al., 2010).

O funcionamento preciso de inúmeras proteínas assegura a correta segregação dos cromossomos e, quando alterados, podem desregular diversos mecanismos de controle, ocasionando erros na separação cromossômica, e levar ao surgimento ou progressão do câncer (BAKHOUM; COMPTON, 2012). Neste contexto, as Aurora-quinases, cujas alterações (superexpressão) estão associadas com a indução de aneuploidia e instabilidade genômica, assim como, envolvidas com a patogênese de diversos tumores, são de particular relevância por desempenharem funções fundamentais no controle de diferentes etapas da divisão celular (HEGYI; MEHES, 2012).

\subsection{Aurora-quinases}

As Aurora-quinases são uma família de Serina/Treonina quinases composta pelas Aurora-quinases A (AURKA), AURKB e AURKC, as quais desempenham funções importantes na estabilidade do fuso e segregação cromossômica (NIKONOVA et al., 2013). Dentre estas, destacam-se a entrada na fase mitótica, a formação dos microtúbulos do fuso e a conclusão da citocinese (CIMINI, 2007; HEGYI; MEHES, 2012).

As Aurora-quinases $A, B$ e $C$ compartilham alta identidade quanto à sequência dos aminoácidos e à estrutura, contendo uma porção $\mathrm{N}$-terminal com propriedade regulatória, um domínio central com atividade quinase dependente de fosforilação e, uma porção C-terminal, comum às três proteínas (Figura 2); além de apresentarem alta homologia com outras espécies (CARMENA; EARNSHAW, 2003). 


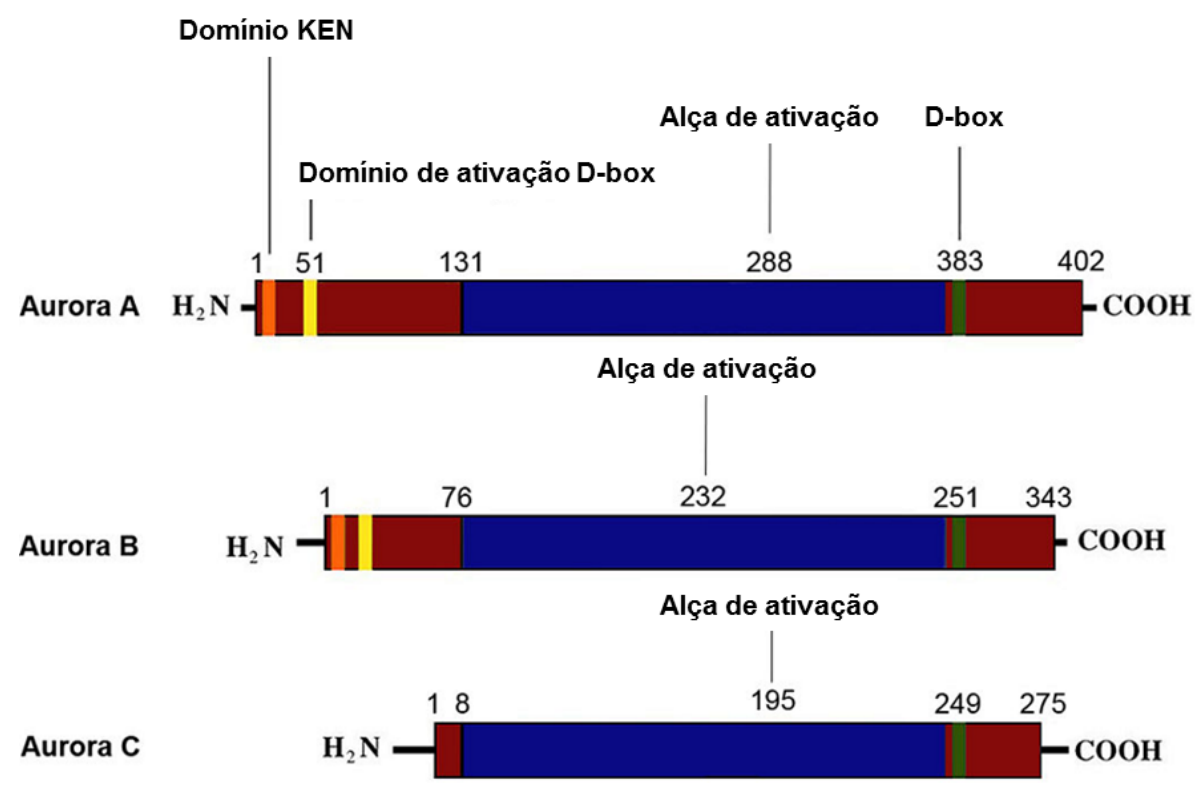

FIGURA 2. Estrutura e domínios das Aurora-quinases. As porções $\mathrm{N}$-terminal e C-terminal das Aurora-quinases contêm domínios com atividade regulatória (d-box e ken) enquanto que a porção central contribui com a atividade catalítica. A porção central possui, também, domínios regulatórios como a alça de ativação, região de autofosforilação proteica (GOLDENSON; CRISPINO, 2015).

A Aurora A, cujo gene se localiza no cromossomo 20q13.2, é encontrada nos centrossomos e microtúbulos do fuso mitótico (KATSHA et al., 2015), auxiliando na maturação dos centrossomos, no controle do alongamento e bipolaridade das fibras do fuso, e participando na regulação do checkpoint do fuso mitótico; assegurando dessa forma, uma separação cromossômica simétrica (KOLLAREDDY et al., 2008) (CARMENA; EARNSHAW, 2003). Ao longo do ciclo celular a AURKA esta expressa em níveis baixos na fase $\mathrm{G} 1 / \mathrm{S}$, os quais se elevam na fase $\mathrm{G} 2$, atingindo o ápice de expressão e atividade proteica no início da mitose (Figura 3) (GOLDENSON; CRISPINO, 2015). Funcionalmente, quando ativada por TPX2 (Targeting protein for Xk/p2), a AURKA se autofosforila na região da Treonina 288 alterando, assim, sua conformação e regulando, consequentemente, a progressão da mitose via fosforilação de diversas proteínas alvo-dependentes (MARUMOTO et al., 2003) (HIROTA et al., 2003) (SATINOVER; BRAUTIGAN; STUKENBERG, 2006). Por outro lado, estudos têm demostrado o papel da AURKA na regulação da autorenovação 
de células-tronco, assim como, na reprogramação e diferenciação celular (LEE, D. F. et al., 2012; LI; RANA, 2012).

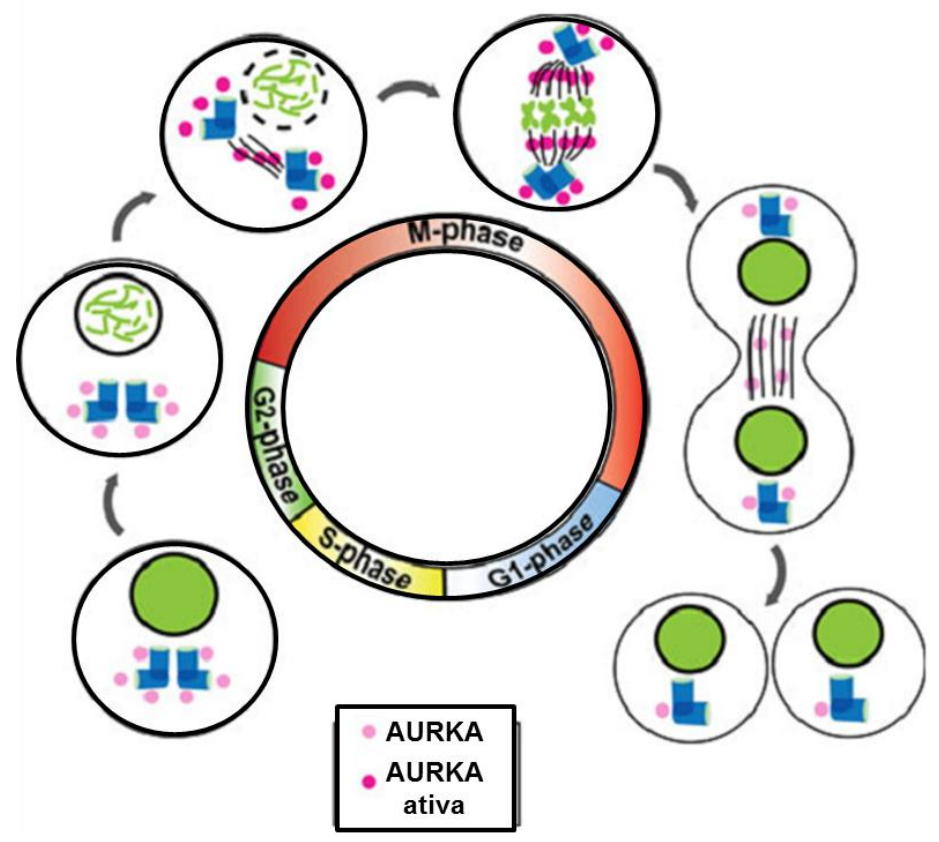

FIGURA 3. Aurora-quinase A (AURKA) no ciclo celular. A AURKA se acumula nos centrossomos na fase $S$ e sofre ativação entre as fases $G 2$ e M. A AURKA ativa se propaga pelos microtúbulos do fuso mitótico até a região central. $A$ inativação e degradação de grande quantidade proteica ocorre até o início da citocinese, sendo detectáveis baixos níveis de AURKA já no início de G1 (adaptado de Nikonova et al., 2013).

A Aurora B, por sua vez, apresenta-se nos centrômeros atuando em diferentes processos, como na condensação dos cromossomos, na bi-orientação dos mesmos às fibras do fuso e na citocinese (DE GROOT et al., 2015). Já, a Aurora $C$ é descrita por participar da espermatogênese, na orientação das fibras do fuso, e atuar na mitose, juntamente com a Aurora $B$, na regulação da dinâmica dos cromossomos (GOLDENSON; CRISPINO, 2015).

O aumento da expressão da $A U R K A$ leva à sobreposição do checkpoint do fuso mitótico, no estágio G1 do ciclo celular, acarretando células tetraploides com grande número de centrossomos que continuam a se dividir. A ativação de checkpoints mitóticos com possível indução de apoptose ocorre, contudo, devido à aneuploidia associada à elevada expressão desta mesma proteína (HEGYI; MEHES, 
2012). Assim, a amplificação genética e superexpressão de AURKA é comum em muitos tipos de tumores sólidos, e esta associada com a aneuploidia, centrossomos supranumerários, fusos mitóticos defeituosos, e resistência à apoptose (NIKONOVA et al., 2013). Da mesma forma, a expressão elevada de AURKB está associada a mau prognóstico em cânceres de cólon, tireoide anaplásico e glioblastoma (MEHRA et al., 2013). Vale ressaltar que tanto AURKA quanto AURKB precisam se associar a outros fatores, como Polo-like quinases (PLKs), para a promoção de uma atividade oncogênica (HEGYI; MEHES, 2012; MEHRA et al., 2013).

De outro modo, a interação da AURKA esta direta ou indiretamente relacionada a atividade de diferentes proteínas que sofrem fosforilação da tirosina quinase, como BRCA1/2 as quais se apresentam inversamente expressas $(\mathrm{OUCHI}$ et al., 2004), ou à via MEK/ERK, favorecendo a agregação celular em diferentes tumores, como cólon e bexiga que apresentam mutação em RAS (RAS ${ }^{\mathrm{V} 12}$ ) (TSENG et al., 2009). Ainda, RAS pode promover a instabilidade genômica pela indução de Aurora-quinase A levando a poliploidia ou aneuploidia cromossômica (YANG, G. et al., 2013). A via PI3K/AKT tambem esta relacionada à indução e ativação de AURKA e AURKB (YANG, J. et al., 2014). Por outro lado, a Aurora-quinase A pode agir indiretamente sobre RAS tendo ação sobre os mecanismos de reparo do DNA (WANG et al., 2014) ou ativar diretamente AKT por meio da fosforilação da Serina 473 (KATSHA et al., 2015) favorecendo a migração celular durante a transição epitélio-mesênquima (GUAN et al., 2007).

Frente ao exposto, fica claro que a identificação e o entendimento de potenciais mecanismos envolvidos na instabilidade cromossômica em diferentes neoplasias pode ter um impacto significativo no entendimento da carcinogênese e sua progressão, bem como no desenvolvimento de terapias específicas voltadas a grupos de risco específicos.

Apesar das largamente exploradas Aurora-quinases terem um papel bem estabelecido na $\mathrm{CIN}$, outras proteínas somente recentemente vem sendo associadas à instabilidade cromossômica. Neste contexto, nossos colaboradores espanhóis, sob liderança do Prof. Carlos Martinez-A, foram responsáveis pela identificação e 
descrição de um gene conhecido como DIDO, associado com processos de instabilidade genômica.

\section{4. $O$ gene DIDO}

O gene DIDO (também conhecido como Death-Associated Transcription Factor 1 - DATF1; ou ainda DIDO1 ou DIO-1, Death Inducer Obliterator 1) foi inicialmente identificado por Differential Display PCR em células pré-B WOL-1 induzidas a apoptose pela retirada de IL-7. De forma similar, o aumento de expressão do mRNA de DIDO foi identificado em diferentes tipos celulares induzidos à apoptose por diferentes estímulos (GARCIA-DOMINGO et al., 2003).

Inicialmente, acreditava-se que a ação de DIDO estaria associada a sua translocação nuclear e à indução de caspases, indicando um potencial mecanismo de ativação transcricional dos promotores das caspases por DIDO (GARCIADOMINGO et al., 2003). No entanto, análises posteriores da composição dos domínios de DIDO, e sua comparação com genes homólogos encontrados em organismos distantes, sugeriram que a apoptose induzida por DIDO seria um efeito secundário relacionado à regulação da estabilidade da cromatina (ROJAS et al., 2005).

O gene DIDO, localizado no cromossomo 20q13.33 em humanos, da origem, por splicing alternativo, a 3 variantes transcricionais que codificam 3 isoformas proteicas denominadas DIDO1, DIDO2 e DIDO3 (FUTTERER et al., 2005). Tais isoformas contêm domínios proteicos, como PHD (Plant Homeodomain) e TFIISM (Transcription Factor S-IIM), normalmente associados à transcrição, e SPOC (Spen paralog and ortholog C-terminal domain), associado à interação entre proteínas (Figura 4) (ROJAS et al., 2005) 


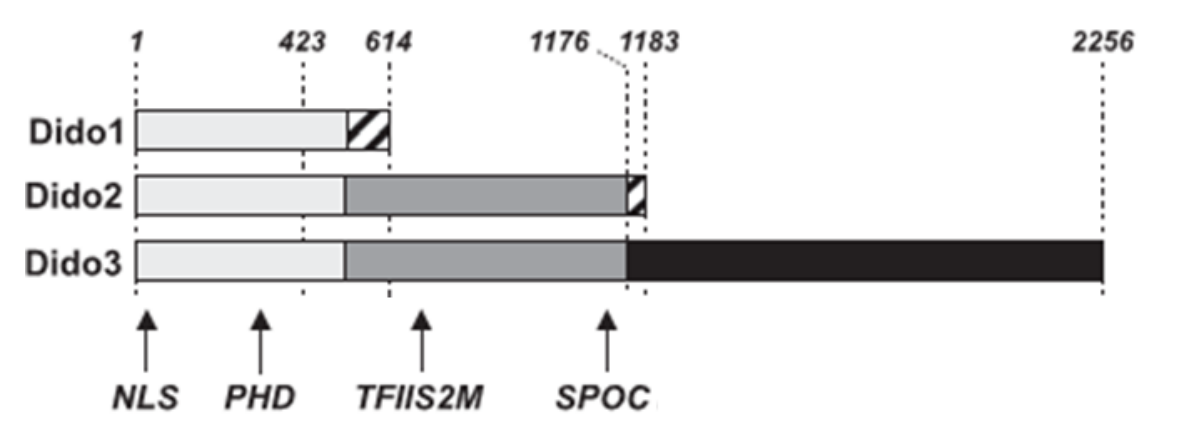

FIGURA 4. Isoformas codificadas pelo locus DIDO (DID01, DIDO2 e DIDO3). Em listrado, fragmentos específicos das isoformas na porção c-terminal. As cores cinza claro, cinza escuro e preto representam, respectivamente, regiões comuns as três isoformas, regiões comuns à DIDO2 e DIDO3 e, região específica de DIDO3. As setas apontam para localização aproximada dos domínios funcionais de DIDO (NLS, nuclear localization signal; PHD, plant homeodomain; TFIISM, transcription factor $s$ domain ii module; SPOC, spen paralog and ortholog c-terminal domain) e a numeração representa os aminoácidos a partir da porção N-terminal (adaptado de Fütterer et al., 2012).

Interessantemente, além dos domínios de DIDO revelarem homologia conservada entre diferentes espécies de eucariotos (ROJAS et al., 2005), estudos recentes evidenciaram uma possível homologia das isoformas de DIDO com proteínas associadas à transcrição, dentre as quais $\mathrm{PHF} 3$, relacionado ao desenvolvimento de gliomas e cuja expressão encontra-se baixa em glioblastomas (FISCHER et al., 2001), e BYE1, descrito por participar do processo de controle do alongamento trancricional de genes ativos, via ligação direta do domínio TLD (TFIISlike domain) às enzimas POLII e POLIII (RNA Polimerases II e III) (KINKELIN et al., 2013; PINSKAYA et al., 2014).

O domínio PHD reconhece e se liga à Histona 3 quando esta apresenta a Lisina 4 tri-metilada (H3K4Me3), uma modificação associada a regiões transcricionalmente ativas (eucromatina) de células somáticas (MELLOR, 2006). De fato, Prieto e colaboradores demonstraram que DIDO3 reconhece $\mathrm{H} 3 \mathrm{~K} 4 \mathrm{Me} 3$, tanto in vitro como in vivo, em fibroblastos embrionários de camundongos, onde DIDO3 se co-localiza com H3K4Me3, mas não quando a Histona 3 se encontra com a lisina 9 tri-metilada (H3K9Me3), modificação associada com regiões transcricionalmente silenciosas (heterocromatina) (PRIETO et al., 2009). A natureza estrutural desta interação foi posteriormente caracterizada por ressonância magnética nuclear (RMN) 
e modelagem molecular, ressaltando as associações do domínio PHD ao peptídeo H3K4Me3 (SANTIVERI et al., 2013).

Tanto DIDO2 como DIDO3 apresentam homologia estrutural conservada com o domínio SPOC da proteína SHARP (SMRT/HDAC1-associated repressor protein), um domínio com importante papel na regulação transcricional e identificado em proteínas relacionadas à apoptose e ao câncer (SANCHEZ-PULIDO et al., 2004), sendo responsável pela interação com os co-repressores SMRT/NCoR (silencing mediator for retinoid and thyroid receptors/nuclear receptor corepressor) e pelo silenciamento transcricional decorrente da montagem de complexos multi-proteicos contendo Histonas Deacetilases (HDACs) (ARIYOSHI; SCHWABE, 2003).

Interessantemente, a presença do domínio SPOC e do domínio PHD em DIDO3, pode estar associada a um mecanismo de controle de repressão transcricional similar ao descrito para o supressor tumoral ING2 (inhibitor of growth 2). Como mencionado, a família ING compartilha com DIDO3 (e outras poucas proteínas), todos os resíduos aminoácidos críticos para o sítio de interação com H3K4Me3 (PENA et al., 2006), no entanto, ao contrario dos outros membros da família ING; ING1 e ING2 se ligam a Histonas De-Acetilases - HDACs, ao invés de Histonas Acetil Transferases - HATs (DOYON et al., 2006). Esta característica particular associa $\mathrm{H} 3 \mathrm{~K} 4 \mathrm{Me} 3$ à repressão transcricional (ao invés de sua ativação) e, portanto, caracteriza um mecanismo de controle particularmente importante em situações de estresse como dano ao DNA, onde o rápido desligamento de genes ligados à proliferação (como demonstrado para a Ciclina D1) é critica para impedir a propagação de células carregando DNA danificado (SHI et al., 2006). Desta forma, a presença dos domínios SPOC e PHD em DIDO3, poderiam estar associadas a um mecanismo de controle de repressão transcricional, similar ao descrito para o supressor tumoral ING2. A família de proteínas ING, assim como DIDO, está envolvida em diversos mecanismos associados a processos tumorigênicos, como o controle da apoptose e da parada do ciclo celular (COLES; JONES, 2009; PICHE; LI, 2010).

A isoforma predominantemente expressa, DIDO3, se encontra em sua maioria no núcleo durante a intérfase e também nos centrossomos, enquanto que, 
na fase mitótica, migra para os microtúbulos do fuso, um comportamento similar à AURKB. Por outro lado, em linhagem epitelial de adenocarcinoma (HeLa), a isoforma DIDO1 é encontrada principalmente no citoplasma e DIDO2 no núcleo (GUERRERO; GAMERO; et al., 2010; GUERRERO; MARTINEZ; et al., 2010; TRACHANA et al., 2007). Ensaios realizados por Gatchalian et al. (2013), demonstram que o deslocamento de DIDO3 é dependente de fosforilação das Treoninas 3 e/ou 6, da Histona 3, as quais quando fosforiladas, desestabilizam a interação PHD/H3K4Me3 (Figura 5) (GATCHALIAN et al., 2013).

A metilação da lisina 4 da Histona 3 ocorre por meio da ação de uma metiltransferase codificada pelo gene MLL (Mixed Lineage Leukemia) da família trithorax, considerado um proto-oncogene devido ao seu envolvimento em translocações ligadas à leucemogênese (CHANG et al., 2010; TENNEY; SHILATIFARD, 2005).
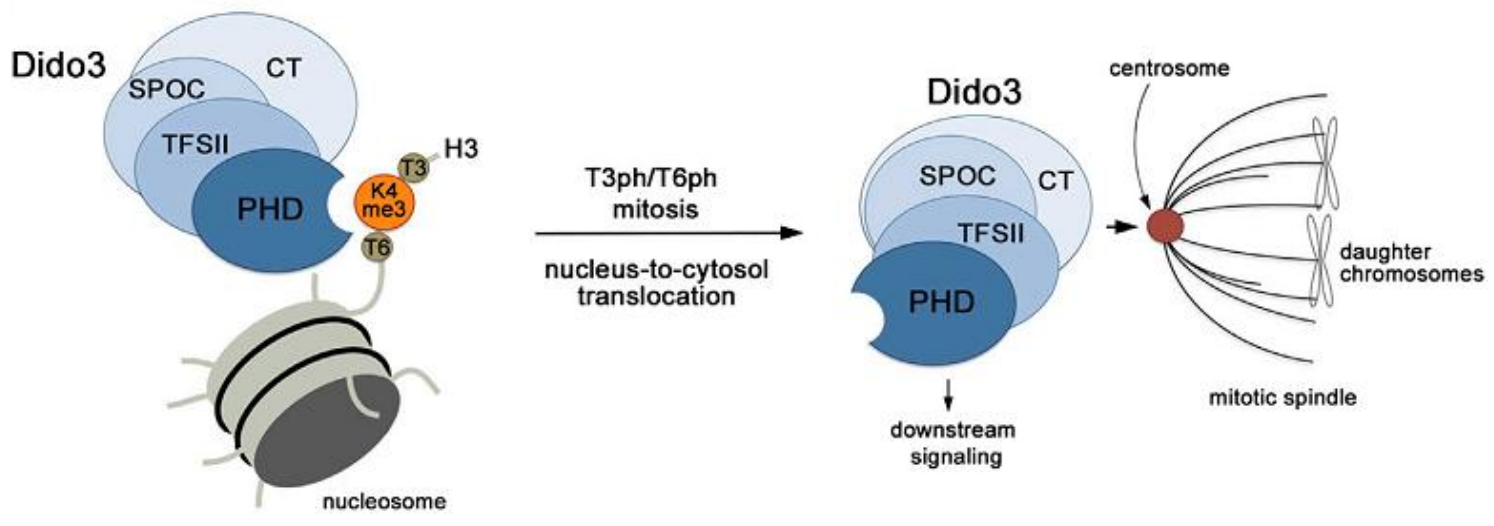

FIGURA 5. Modelo de translocação de DIDO3 da cromatina para fibras do fuso. A fosforilação das Treoninas 3 e 6, na Histona 3, desestabiliza a interação do domínio PHD/K4me3 promovendo o deslocamento de DIDO3, do núcleo para o citoplasma, via fibras do fuso. (extraído de Gatchalian et al., 2013).

Considerando a importância de DIDO3 na manutenção da estabilidade cromossômica, vale ressaltar que um estudo demonstrou que a inativação desta proteína promoveu não somente a amplificação dos centrossomos, como a atenuação dos pontos de checagem do fuso mitótico (SAC), acarretando instabilidade cromossômica e aneuploidias (GUERRERO; GAMERO; et al., 2010; GUERRERO; MARTINEZ; et al., 2010; TRACHANA et al., 2007). 
Interessantemente, camundongos que não expressam DIDO (DIDOneo/neo) desenvolvem alterações hematológicas com características de síndromes mielodisplásicas ou desordens mieloproliferativas (SMD/DMP) levando ao aparecimento de alterações cromossômicas e, eventualmente, a óbito após um grande período de latência (FUTTERER et al., 2005). Ainda, neste mesmo trabalho, a avaliação dos níveis de expressão das variantes de DIDO em alguns poucos pacientes revelaram níveis reduzidos destas variantes na medula óssea em 6 dos 11 pacientes com SMD, comparados a controles saudáveis. Estes resultados, revelaram que a perda de função ou a expressão reduzida de DIDO levaria à instabilidade cromossômica e, potencialmente, estaria envolvida em alterações hematológicas como a SMD.

É evidente que proteínas como as AURKs, DIDO e outras, têm papel fundamental na manutenção da estabilidade cromossômica, e que alterações em suas atividades ou em seus níveis de expressão podem ter a instabilidade cromossômica como consequência, com o eventual surgimento de neoplasias.

Diversas doenças hematológicas podem apresentar alterações cromossômicas e cariótipos complexos, muitas vezes com importante valor prognóstico, que podem decorrer de mecanismos relacionados à instabilidade cromossômica.

\subsection{Instabilidade cromossômica e alterações hematológicas}

Dentre as alterações hematológicas com registro de instabilidade cromossômica, as já mencionadas SMDs representam distúrbios clonais caracterizados por defeitos na maturação de progenitores mieloides, citopenia periférica decorrente da ineficácia na hematopoese e displasia medular (VALENT et al., 2010). Assim, indivíduos acometidos por esta doença podem apresentar queda na contagem de glóbulos brancos e plaquetas. Com a progressão da doença, os pacientes, junto aos quais os fatores de risco mais recorrentes estão a idade avançada e a exposição à quimio e radioterápicos, tornam-se susceptíveis a falhas na medula óssea, com possível transformação da doença para Leucemia Mieloide Aguda (LMA) (SCOTT; DEEG, 2010) (FANG; VARNEY; STARCZYNOWSKI, 2012). 
Registros de alterações citogenéticas são detectados em grande proporção nos pacientes com SMD, estando entre os mais comuns a presença de deleções (del(5q); del(20q)), monossomias (7 mono) e trissomias 8 (tri 8 ), as quais auxiliam no prognóstico e tratamento das patologias relacionadas (FANG et al., 2012).

Notavelmente, a superexpressão da Aurora-quinase A está associada com a presença de anomalias citogenéticas desfavoráveis em pacientes com LMA (LUCENA-ARAUJO et al., 2011); ilustrando a relevância desta família proteica nos processos de CIN relacionados a neoplasias mieloides.

Além das SMDs e das LMAs, outras doenças hematológicas estão associadas com instabilidade cromossômica. A exemplo, defeitos que levam à amplificação do centrossomo, e a consequente formação de microtúbulos e fusos mitóticos desorganizados, são frequentemente detectados em diversos subtipos de células B malignas, incluindo a leucemia linfoide crônica (LLC), levando a erros na segregação cromossomal e aneuploidia; correlacionando-se com a atividade proliferativa dos linfócitos e com casos clínicos de alta agressividade de LLC (CHAN, 2011).

Em particular, os estudos sobre LLC são de grande relevância por esta leucemia ser a mais comum em países ocidentais nos quais a população mais atingida é representada por indivíduos entre 65 e 74 anos, com uma incidência ajustada por idade de aproximadamente 4,6 novos casos por 100.000 habitantes por ano, segundo estimativa dos registros de 2009 a 2013, e correspondendo a cerca de $1,1 \%$ de todas as neoplasias registradas nos Estados Unidos da América para o ano de 2016 (http://seer.cancer.gov/statfacts/html/clyl.html).

A LLC caracteriza-se pelo acúmulo de pequenas células $B$ maduras no sangue, medula óssea e órgãos linfoides secundários. Registros de extrema heterogeneidade clínica em pacientes com LLC resultam, muitas vezes, de anormalidades cromossômicas oriundas de lesões citogenéticas, como deleções (17p13, 11q22, 13q14) e/ou translocações, ou mesmo mutações de genes cruciais para a manutenção da sobrevivência celular, como o fator de transcrição TP53 (FOA et al., 2013). Ainda, a maioria dos pacientes com a forma clínica mais agressiva da 
doença apresenta marcadores moleculares, como alta expressão de ZAP-70 e imunoglobulina de cadeia pesada (IGHV) não mutada (ZHANG et al., 2013).

Várias alterações cromossômicas estão associadas com um pior prognóstico nos pacientes com LLC (DOHNER et al., 2000; JULIUSSON et al., 1990). Mais especificamente, LLCs com certas alterações cromossômicas específicas apresentam porcentagens de ZAP-70 significativamente mais altas (FABBRI et al., 2011), indicando uma associação da instabilidade cromossômica com o sub-tipo mais agressivo de células B, da LLC.

Notadamente, um estudo revelou que a Aurora-quinase $A$ estaria superexpressa em células de pacientes com LLC (em comparação com linfócitos de indivíduos saudáveis), apresentando uma localização principalmente nuclear e estando associada à presença da histona H3 acetilada, sugerindo uma superativação da mesma. Neste mesmo estudo, anormalidades cromossômicas foram detectadas em 28 (67\%) dos 42 pacientes com níveis elevados de Aurora A, incluindo trissomia do cromossomo 12 e deleção do gene ATM (del11q23), alterações sabidamente associadas com um curso clínico acelerado em doentes com LLC. Este resultados indicam que a superexpressão da Aurora-quinase A na LLC poderia estar envolvida na gênese de anormalidades cromossômicas (INAMDAR et al., 2008).

Estudos posteriores, realizados por nosso grupo de pesquisa, revelaram que as Aurora-quinases $A$ e $B$ são expressas em níveis mais elevados em células proliferativas da LLC localizadas na medula óssea, revelando uma potencial contribuição deste conhecido nicho proliferativo envolvido com recaídas, com um potencial mecanismo de instabilidade cromossômica mediado pelas AURKs (DE PAULA CARETA et al., 2012).

Estes estudos destacam o potencial envolvimento das AURKS na LLC através da instabilidade genômica. Obviamente, entender os mecanismos por traz da instabilidade cromossômica, observada em diferentes doenças hematológicas, teria implicações relevantes tanto conceituais como práticas, permitindo o eventual desenvolvimento de terapias alternativas. 
Apesar de muitos estudos revelarem uma associação entre níveis de expressão alterados de diferentes genes centrais na divisão celular (como AURKs e outros) com a instabilidade cromossômica, os mecanismos regulatórios responsáveis por estas alterações são muito menos conhecidos. Neste contexto, uma grande atenção tem sido dada a um grupo de moléculas regulatórias chamadas microRNAs, capazes de regular a expressão gênica, principalmente de forma póstranscricional.

\section{6. microRNAs e doenças hematológicas}

Os microRNAs (miRNAs) participam da regulação celular via controle póstranscricional de genes envolvidos em diversos processos biológicos e em diferentes contextos (FILIPOWICZ; BHATTACHARYYA; SONENBERG, 2008) (AMBROS; LEE, 2004) (BARTEL, 2004).

A biogênese dos miRNAs se inicia no núcleo por meio da RNA polimerase II a qual sintetiza os pri-miRNA (LEE, Y. et al., 2002) formando uma estrutura de "hairpin" secundária composta de bases complementares pareadas (AMBROS; LEE, 2004) (SINGH et al., 2008). Estas são processadas, via complexo Drosha-DGCR8, gerando um miRNA precursor (pre-miRNA) (LEE, Y. et al., 2003) o qual é exportado para o citoplasma, via Exportina 5, e processado gerando um miRNA de fita dupla, via complexo RNaselll-Dicer (LUND et al., 2004). Uma das fitas deste miRNA (passageira) é degradada via complexo RISC, gerando um microRNA maduro de fita simples de cerca de 22 nucleotídeos (AMBROS, 2003; MEDINA; SLACK, 2008) que age ou pela complementaridade total de bases, promovendo a clivagem do mRNA, ou pelo alinhamento parcial promovendo o bloqueio de sua tradução em proteínas e/ou a desestabilização e degradação do mRNA (Figura 6) (CALIN et al., 2004). 


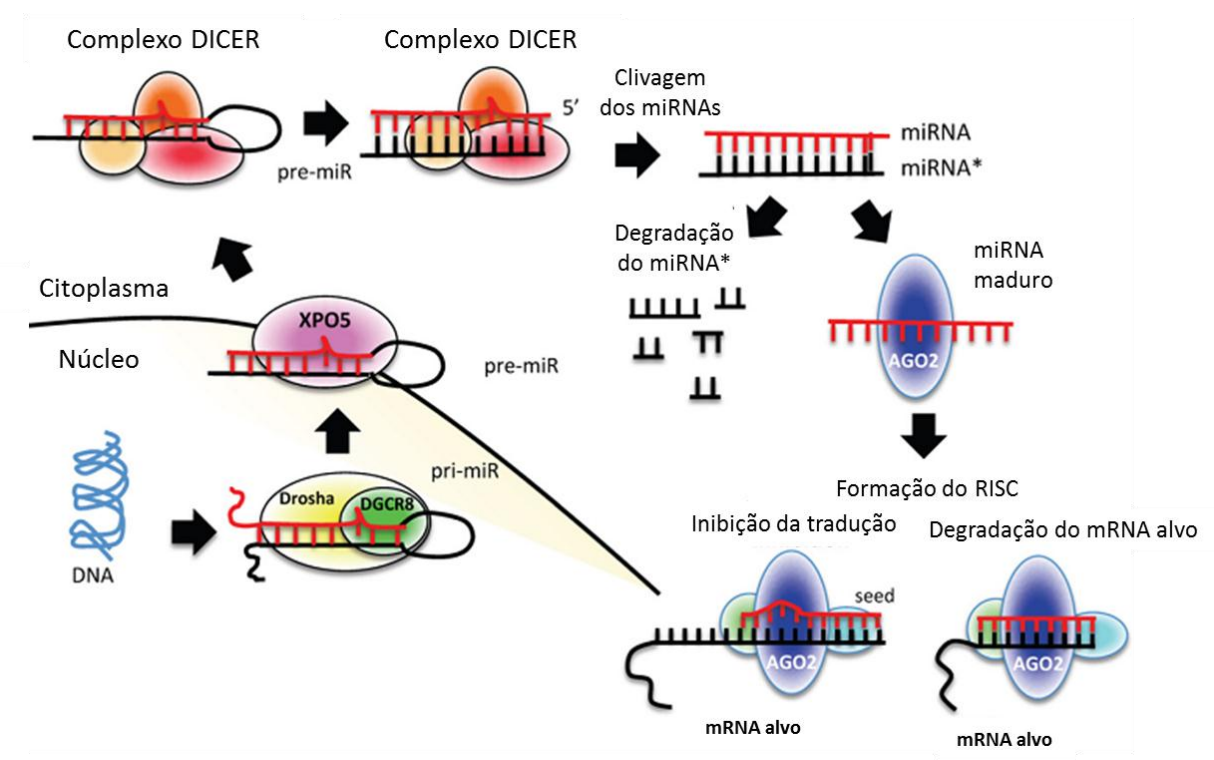

FIGURA 6. Representação esquemática da biogênese e atuação do miRNA. Cada miRNA é transcrito por meio da RNA polimerase II (pri-miRNA) no núcleo celular. O pri-miRNA é reconhecido pelo complexo enzimático Drosha-DGCR8 e processado em pre-miRNA, o qual é exportado para o citoplasma via exportina 5 (XPO5), sofrendo novo processamento e clivagem pelo complexo DICER gerando duas fitas de miRNAs (miRNA*-miRNA). Apenas uma das fitas de miRNA é incorporada ao complexo RISC. O grau de homologia do miRNA maduro à sequência 3' UTR do mRNA alvo irá determinar a repressão da tradução ou degradação deste; extraído e adaptado de (BERTOLI; CAVA; CASTIGLIONI, 2015).

Tendo em vista sua importante função regulatória, muitos estudos recentes têm explorado o potencial papel dos microRNAs nos mais diversos contextos biológicos, incluindo neoplasias hematológicas. Diversos genes precursores de miRNAs são encontrados em regiões cromossômicas com alguma alteração no câncer indicando uma possível participação dos miRNAs na patogênese do câncer, em humanos (CALIN et al., 2004).

De nosso interesse específico, o papel dos microRNAs na LLC vem ganhando atenção crescente nos últimos anos. Por exemplo, a frequente deleção do locus $13 q 14.3$ em células malignas de pacientes com LLC, onde se encontram os miR-15a e miR-16-1, leva a uma redução nos níveis destes microRNAs com consequente queda da modulação da tradução de mRNAs alvo oncogênicos, em LLC (CALIN et al., 2002). 
Ainda, os membros da família do miR-29 são expressos em níveis mais baixos no sub-tipo mais agressivo de células $B$ da leucemia linfocítica crônica (LLCB com elevada expressão de ZAP-70 ou fenótipo não mutado de $\lg \mathrm{HV}(\mathrm{H})$ ), em comparação com o sub-tipo indolente (CALIN et al., 2005; CALIN et al., 2004). O oncogene TCL1 (T-cell leukemia/lymphoma 1), cujos níveis de transcrição elevados estão associados com o subtipo agressivo de LLC (HERLING, M. et al., 2006), é um alvo de miR-29, caracterizando um mecanismo pelo qual níveis baixos de miR-29 levariam ao acúmulo de TCL1 e, assim, a um comportamento celular mais agressivo (PEKARSKY et al., 2006). Em contraste, de maneira geral, o miR-29a é um dos miRs mais expresos em LLC (ZANETTE et al., 2007) e a sua expressão forçada em células $B$ de rato resulta no desenvolvimento de leucemia com características de LLC; o que seria parcialmente dependente da inibição do supressor de tumor peroxidasin (PXDN) por miR-29 (SANTANAM et al., 2010).

Estes resultados demonstram como variações nos níveis de um determinado microRNA podem ter impactos diversos (ou opostos), dependendo do contexto celular e dos processos biológicos afetados, num determinado momento, durante o surgimento ou ao longo da evolução de uma neoplasia.

Mais importante ainda, dentro do contexto do presente estudo, Bomben e colaboradores demonstraram que a família dos miRNAs do cluster miR-17 92 tem expressão elevada nas LLCs IGHV não-mutadas (ou Zap70+) (BOMBEN et al., 2012).

\subsection{Justificativa do estudo}

A superexpressão das Aurora-quinases tem associação estabelecida com a instabilidade cromossômica, um processos de grande importância na gênese e na progressão de diversas neoplasias. Outras proteínas vêm sendo associadas à manutenção da estabilidade cromossômica, como é o caso de DIDO, cujos baixos níveis ou perda de função levam ao surgimento de alterações cromossômicas e à síndrome mieloproliferativa em camundongos.

Os processos de instabilidade cromossômica têm grande importância na gênese e na progressão de doenças hematológicas como a SMD e a LLC, no 
entanto, faltam estudos associando as Aurora-quinases ou DIDO a estas doenças hematológicas. Obviamente, identificar e entender os mecanismos por traz da instabilidade cromossômica observada na SMD e a LLC tem implicações relevantes, tanto conceituais como práticas, permitindo o eventual desenvolvimento de terapias alternativas. Finalmente, apesar da conhecida associação entre níveis de expressão alterados de diferentes genes com a instabilidade cromossômica, os mecanismos regulatórios responsáveis por estas alterações são pouco conhecidos. Os microRNAs, capazes de regular a expressão gênica principalmente de forma póstranscricional, são candidatos naturais a serem investigados neste contexto. 


\subsection{Objetivo geral}

Avaliar a possível associação das Aurora-quinases e de DIDO com a presença de alterações cariotípicas, decorrentes de instabilidade cromossômica, na síndrome mielodisplásica e na leucemia linfoide crônica e, caso identificada, explorar os possíveis mecanismos regulatórios envolvidos.

\subsection{Objetivos específicos}

> Caracterizar de forma detalhada, em humanos, a estrutura gênica do locus DIDO e de seus transcritos variantes.

$>\quad$ Avaliar e identificar os sítios alvo de microRNAs presentes na extremidade 3`UTR das variantes transcricionais de DIDO (1, 2 e 3$)$.

> Avaliar os níveis dos mRNAs de AURKA e AURKB e de DIDO1, 2 e 3 em amostras de sangue periférico derivadas de pacientes com SMD ou LLC, com ou sem alterações cromossômicas, e em amostras controle de sangue periférico e de medula óssea. Identificar potenciais associações entre os níveis e a instabilidade cromossômica nestas amostras ou critérios de agressividade da doença.

$>$ Avaliar, nas mesmas amostras de pacientes e controles, os níveis de expressão do regulador transcricional do gene $A U R K A$ (o fator E2F1), e do pri-miR do cluster miR-17 92, hospedeiro de microRNAs com sítios alvo nas variantes de DIDO.

> Avaliar o efeito do silenciamento de AURKA (por siRNA) sobre a expressão dos mRNAs de E2F1, MIR17HG e das isoformas de DIDO.

> Avaliar o efeito dos microRNAs miméticos do cluster miR-17 92 sobre as isoformas transcricionais de DIDO.

> Avaliar o efeito do silenciamento das três variantes transcricionais de DIDO (por siRNA) sobre as expressão das Aurora-quinases e das próprias isoformas de DIDO. 


\subsection{Amostras de pacientes}

Foram avaliadas amostras provenientes de 87 pacientes com diagnóstico de doenças hematológicas distintas incluindo 43 pacientes com síndrome mielodisplásica - SMD (21 com cariótipo normal e 22 com alterações cariotípicas), 44 pacientes com leucemia linfocítica crônica - LLC (12 com cariótipo normal e $32 \mathrm{com}$ alterações cariotípicas) (Tabelas 5 e 6 do Anexo). Além disso, amostras controle foram obtidas a partir de medula óssea total - $M O(n=5)$ ou células mononucleares do sangue periférico - SP $(n=17)$ de doadores saudáveis normais.

\subsection{Caracterização da estrutura gênica do locus DIDO e desenho dos primers para quantificação de suas variantes e demais transcritos}

Para a caracterização da estrutura gênica do locus DIDO, buscas foram feitas no "National Center for Biotechnology Information - NCBl" (vwww.ncbi.nlm.nih.gov), afim de identificar todos os transcritos variantes depositados na base de sequências referências curadas (RefSeq). Uma vez identificados, eles foram alinhados ao genoma utilizando a ferramenta "Basic Local Aligment Tool - BLAT" do site "UCSC Genome Browser" (genome.ucsc.edu). Apesar de termos identificado que cada uma das isoformas proteicas de DIDO pode ser traduzida a partir de dois transcritos, derivados de promotores alternativos (Tabela 1), eles diferem apenas no início da extremidade 5 '-UTR e, portanto, os primers foram desenhados na extremidade 3 'UTR, de forma a garantir a quantificação independente de cada uma das 3 variantes de DIDO (1, 2 e 3 ), porém, cada quantificação correspondendo à soma dos transcritos derivados de ambos os promotores.

TABELA 1. VARIANTES TRANSCRICIONAIS DE DIDO

\begin{tabular}{lll}
\hline Variante & Promotor & Reference Seq. \\
\hline DIDO 1-v1 & Distal & NM_022105.4 \\
DIDO 1-v2 & Proximal & NM_080796.3 \\
DIDO 2-v3 & Distal & NM_080797.3 \\
DIDO 2-v6 & Proximal & NM_001193370.1 \\
DIDO 3-v4 & Distal & NM_033081.2 \\
DIDO 3-v5 & Proximal & NM_001193369.1 \\
\hline
\end{tabular}


Por meio da ferramenta Primer3Plus (http://www.primer3plus.com), os primers foram desenhados nos dois últimos exons de cada transcrito, sendo os primers reversos desenhados nas regiões 3' específicas de cada variante, representados na figura 7 . Os parâmetros para desenho dos primers foram os padrões para qPCR (anelamento e extensão combinados) para uso em conjunto com o reagente de detecção SYBRGreen®. Esta estratégia nos permitiu a detecção e quantificação específica das 3 variantes de DIDO, bem como das AURKs, GID8 e dos controles endógenos GAPDH e $\beta$-Actina. A tabela com as informações relacionadas aos primers de qPCR desenhados é mostrada logo abaixo (Tabela 2). As análises de expressão gênica de E2F1 e MIR17HG foram realizadas utilizando sondas TaqMan® (HS00153451 e HS01382425_m1, respectivamente). As análises de expressão gênica de AURKA e AURKB, em amostras de pacientes, foram realizadas utilizando sondas TaqMan® (HS00269212_m1 e HS00177782_m1, respectivamente).

TABELA 2. SEQUÊNCIA DOS PRIMERS.

\begin{tabular}{|c|c|c|c|}
\hline Primer & Sequence (5' to 3') & Targeted Transcripts & Amplicon Size \\
\hline Dido1-F & GTC TTC CGA AAT GCG GTG CTC A & Common 3'of & \multirow{2}{*}{$365 b p$} \\
\hline Dido1-R & ATG GTG CAG CCG GTG TCT GT & $\mathrm{v} 1$ and v2 & \\
\hline Dido2-F & ATC GCA CCG AAG ACA GTT TG & Common 3'of & \multirow{2}{*}{$331 b p$} \\
\hline Dido2-R & ACT CAG CAG GGC ATG TCA G & V3 and v6 & \\
\hline Dido3-F & ACT CTT GCC CTT TGA GGG ACC A & Common 3'of & \multirow{2}{*}{ 133bp } \\
\hline Dido3-R & TCG GGT CCG CTT TTC GTC CA & V4 and v5 & \\
\hline GID8-F & TTT GAC AGT CCC GAG GAG TC & & \multirow{2}{*}{ 224bp } \\
\hline GID8-R & GGT GTT GAC TCG CGA TTT TC & NA & \\
\hline AURKA-F & CAG TAC ATG CTC CAT CTT CCA G & & \multirow[b]{2}{*}{ 123bp } \\
\hline AURKA-R & AAA GAA CTC CAA GGC TCC AG & NA & \\
\hline AURKB-F & ACC CTT TGA GAG TGC ATC AC & & \multirow{2}{*}{ 115bp } \\
\hline AURKB-R & CCT GAG CAG TTT GGA GAT GAG & INA & \\
\hline GAPDH-F & GAAGGTGAAGGTCGGAGTC & & \\
\hline GAPDH-R & GAAGATGGTGATGGGATTTC & & \\
\hline B-Actina -F & ACCTTCTACAATGAGCTGCG & & \\
\hline B-Actina -R & CCTGGATAGCAACGTACATGG & & \\
\hline DidoPD-F & AGG CGT TGG AGC GCG GAA AT & Common 5'of & \multirow{2}{*}{ 89bp } \\
\hline DidoPD-R & AGA GGC TGT TCC CGT GGA GT & v1, v3 and v4 & \\
\hline DidoPP-F & TCG GGG AAA TGG CTG CGA GA & Common 5 of & \multirow{2}{*}{$61 \mathrm{bp}$} \\
\hline DidoPP-R & AGA GGC TGT TCC CGT GGA GT & $\mathrm{v} 2, \mathrm{v} 6$ and $\mathrm{v} 5$ & \\
\hline
\end{tabular}

\subsection{Desenho e aquisição dos siRNAs para knockdown específico das variantes de DIDO e das AURKs}

Para desenho e compra dos siRNAs alvo-específicos dos transcritos de DIDO, foi utilizada a ferramenta "Gene Assist Custom siRNA Builder" (Life Technologies). O desenho dos siRNAS foi feito de forma a garantir a especificidade 
para cada uma das variantes (independente do início de transcrição alternativo); ou seja, para DIDO1, o siRNA deveria ter ambas as variantes desta isoforma (v1 e v2) como alvo e, ao mesmo tempo, não ter as variante de DIDO2 (v3 ou v6) ou de DIDO3 (v4 ou v5), ver tabela 1 com as variantes.

Para os siRNAs contra os transcritos das AURKs, utilizamos siRNAs prevalidados disponíveis comercialmente. A tabela 3 contém as informações relacionadas aos siRNAs utilizados.

TABELA 3. SEQUÊNCIA DOS SIRNAS

\begin{tabular}{|c|c|c|c|}
\hline siRNA & & Sequência & RefSeq Targets \\
\hline $\begin{array}{l}\text { siDIDO - } \\
\text { s501253 }\end{array}$ & $\begin{array}{l}\left(5^{\prime} \text { to } 3^{\prime}\right) \\
\text { Antisense }\end{array}$ & $\begin{array}{l}\text { GGA UGA GAC UCA UUC AGA ATT } \\
\text { UUC UGA AUG AGU CUC AUC CTG }\end{array}$ & $\begin{array}{l}\text { NM_001193370.1; NM_001193369.1; } \\
\text { NM_022105.4; NM_080796.3; } \\
\text { NM_080797.3; NM_033081.2 }\end{array}$ \\
\hline $\begin{array}{l}\text { siDIDO1 - } \\
\text { s528647 }\end{array}$ & $\begin{array}{l}\left(5^{\prime} \text { to } 3^{\prime}\right) \\
\text { Antisense }\end{array}$ & $\begin{array}{l}\text { CUU AAU GAU UGA UUC UUU ATT } \\
\text { UAA AGA AUC AAU CAU UAA GGT }\end{array}$ & NM_022105.4; NM_080796.3 \\
\hline $\begin{array}{l}\text { siDIDO1 - } \\
\text { s528648 }\end{array}$ & $\begin{array}{l}\left(5^{\prime} \text { to } 3^{\prime}\right) \\
\text { Antisense }\end{array}$ & $\begin{array}{l}\text { CCU UGG ACU UGG UAU UCU ATT } \\
\text { UAG AAU ACC AAG UCC AAG GCA }\end{array}$ & NM_022105.4; NM_080796.3 \\
\hline $\begin{array}{l}\text { siDIDO2 - } \\
\text { s528649 }\end{array}$ & $\begin{array}{l}\left(5^{\prime} \text { to } 3^{\prime}\right) \\
\text { Antisense }\end{array}$ & $\begin{array}{l}\text { GCA CGU UCC UUG GAA AGU ATT } \\
\text { UAC UUU CCA AGG AAC GUG CAA }\end{array}$ & NM_001193370.1; NM_080797.3 \\
\hline $\begin{array}{l}\text { siDIDO2 - } \\
\text { s528650 }\end{array}$ & $\begin{array}{l}\left(5^{\prime} \text { to } 3^{\prime}\right) \\
\text { Antisense }\end{array}$ & $\begin{array}{l}\text { ACU UAA CAA UAA UGA CAU ATT } \\
\text { UAU GUC AUU AUU GUU AAG UCT }\end{array}$ & NM_001193370.1; NM_080797.3 \\
\hline $\begin{array}{l}\text { siDIDO3 - } \\
\text { s528651 }\end{array}$ & $\begin{array}{l}\left(5^{\prime} \text { to } 3^{\prime}\right) \\
\text { Antisense }\end{array}$ & $\begin{array}{l}\text { CCU CCG UUG UUA GAU CCG ATT } \\
\text { UCG GAU CUA ACA ACG GAG GTG }\end{array}$ & NM_001193369.1; NM_033081.2 \\
\hline $\begin{array}{l}\text { siDIDO3 - } \\
\text { s528652 }\end{array}$ & $\begin{array}{l}\left(5^{\prime} \text { to } 3^{\prime}\right) \\
\text { Antisense }\end{array}$ & $\begin{array}{l}\text { CCA UCU UAG AAG AAG CGA ATT } \\
\text { UUC GCU UCU UCU AAG AUG GTC }\end{array}$ & NM_001193369.1; NM_033081.2 \\
\hline $\begin{array}{l}\text { siAURKA- } \\
\text { s197 }\end{array}$ & $\begin{array}{l}\left(5^{\prime} \text { to } 3^{\prime}\right) \\
\text { Antisense }\end{array}$ & $\begin{array}{l}\text { GGA UCA GCU GGA GAG CUU ATT } \\
\text { UAA GCU CUC CAG CUG AUC CAA }\end{array}$ & $\begin{array}{l}\text { NM_003600.3; NM_198433.2; } \\
\text { NM_001323305.1; NM_198434.2; } \\
\text { NM_198436.2; NM_001323304.1; } \\
\text { NM_198435.2; NM_198437.2; } \\
\text { NM_001323303.1 }\end{array}$ \\
\hline $\begin{array}{l}\text { siGAPDH- } \\
\text { Positive Control }\end{array}$ & $\begin{array}{l}\left(5^{\prime} \text { to } 3^{\prime}\right) \\
\text { Antisense }\end{array}$ & NA & NM_002046 \\
\hline $\begin{array}{l}\text { siCtr\#2- } \\
\text { Negative Control }\end{array}$ & $\begin{array}{l}\left(5^{\prime} \text { to } 3^{\prime}\right) \\
\text { Antisense }\end{array}$ & NA & NA \\
\hline
\end{tabular}

\subsection{Caracterização dos sítios alvo de microRNAs na Região 3’- UTR dos transcritos variantes de DIDO}

Para identificarmos sítios preditos como potenciais alvos de microRNAs de nosso interesse (no contexto deste trabalho), os identificadores RefSeq dos três transcritos alternativos de DIDO foram utilizados para uma busca no banco de dados online (microrna.org). A posição relativa de cada microRNA foi utilizada para gerar um esquema dos sítios de interesse. Para realização de ensaios funcionais, as moléculas sintéticas mimicas dos microRNAs dupla-fita foram adquiridas por meio da Ambion (Life Technologies), tabela 4. 
TABELA 4. SEQUÊNCIA DOS miRNAs

\begin{tabular}{lccl}
\hline Mature_ID_miRBase & Ambion ID & No Catalogo & Mature_Seq \\
\hline hsa-miR-18a-5p & PM12973 & AM17100 & UAAGGUGCAUCUAGUGCAGAUAG \\
\hline hsa-miR-19a-3p & PM10649 & AM17100 & UGUGCAAAUCUAUGCAAAACUGA \\
\hline hsa-miR-20a-5p & PM10057 & AM17100 & UAAAGUGCUUAUAGUGCAGGUAG \\
\hline hsa-miR-92a-3p & PM10916 & AM17100 & UAUUGCACUUGUCCCGGCCUGU \\
\hline Negative Control\#1 & & AM17110 & NA
\end{tabular}

\subsection{Ensaios funcionais}

\subsubsection{Linhagem celular e condições de cultivo}

Para o desenvolvimento dos ensaios funcionais utilizamos uma linhagem celular humana oriunda de carcinoma embrionário de testículo (NTERA-2), cuja padronização de transfecção já se apresentava estabelecida no laboratório. Para realização dos experimentos, as células estocadas em nitrogênio líquido $\left(-195^{\circ} \mathrm{C}\right)$ foram descongeladas e colocadas em cultivo em meio de cultura DMEM ${ }^{\circledR}$ (Gibco), suplementado com $10 \%$ de soro bovino fetal (SBF) (HyClone, Thermo Scientific) e $1 \%$ de antibiótico (10.000U/mL penicilina/ $10.000 \mu \mathrm{g} / \mathrm{mL}$ estreptomicina; Gibco®), e mantidas em incubadora de $\mathrm{CO}_{2}$ umidificada e com controle de temperatura (5\% de $\mathrm{CO}_{2} ; 85 \%$ de umidade relativa; $37^{\circ} \mathrm{C}$ ).

\subsubsection{Transfecção dos siRNAs/miRNAs em NTERA-2}

Primeiramente, para o preparo dos reagentes de transfecção, foram calculadas concentrações finais de 30nM siRNAs/miRNAs por poço que foram diluídos em Meio Opti-MEM® para um volume de $115 \mu \mathrm{L} /$ well e incubados por 5 minutos à temperatura ambiente. Em seguida, volumes de $1,15 \mu \mathrm{L} /$ well do agente transfectante Lipofectamina $2000 \AA$ foram diluídos em Meio Opti-MEM® para um volume de $115 \mu \mathrm{L} /$ well e incubados por 5 minutos à temperatura ambiente. Aos siRNAs/miRNAs foi adicionado o agente transfectante para um volume final de $230 \mu \mathrm{L} /$ well sendo a mistura, em seguida, pipetada aos poços e a placa de 12 poços incubada à temperatura ambiente e ao abrigo da luz, por 30 minutos.

Após este período, para experimentos cuja coleta das células ocorreu 72 horas pós-transfecção, $9,2 \times 10^{4}$ células/well, em meio de cultura DMEM 
suplementado com $10 \%$ de SBF sem antibiótico, foram pipetadas aos poços seguindo a técnica de transfecção reversa, para um volume final de $1150 \mu \mathrm{L} /$ well. Já, para experimentos cuja coleta das células ocorreu 120 horas pós transfecção, $4,6 \times 10^{4}$ células/well, em meio de cultura DMEM suplementado com $10 \%$ de SBF sem antibiótico, foram pipetadas aos poços seguindo a técnica de transfecção reversa, para um volume final de $1150 \mu \mathrm{L} /$ well. As placas foram, então, homogeneizadas e mantidas em incubadora de $\mathrm{CO}_{2}$ umidificada e com controle de temperatura ( $5 \%$ de $\mathrm{CO} 2 ; 85 \%$ de umidade relativa; $37^{\circ} \mathrm{C}$ ) por 72 horas e 120 horas, respectivamente, sendo o meio de cultura DMEM, suplementado com $10 \%$ de SBF sem antibiótico, substituído após 48 horas do início das transfecções.

\subsection{Análise da expressão gênica}

\subsubsection{Coleta das células, extração e quantificação do RNA}

As células NTERA-2 foram transfectadas em placas de 12 poços (sessão 3.3.1), utilizando siRNAs alvo específicos contra AURKA e contra as isoformas de DIDO, assim como miRNAs miméticos da família do cluster miR-17 92, e foram mantidas em cultura por 72 e 120 horas, a partir do início da transfecção. Ao final destes períodos, as células foram lavadas uma vez com PBS $1 \mathrm{X}$ e aos poços foram adicionados $250 \mu \mathrm{L}$ de PBS/DEPC seguido de $750 \mu \mathrm{L}$ de TRIzol LS® (Invitrogen), para extração do RNA total. Após homogeneização, a mistura com as células lisadas foram transferidas para microtubos de $1,5 \mathrm{~mL}$ os quais foram mantidos em freezer $80^{\circ} \mathrm{C}$ até o momento da extração.

Para a extração, as amostras foram descongeladas e adicionadas de $10 \mu \mathrm{L}$ de glicogênio e $200 \mu \mathrm{L}$ de clorofórmio. As amostras foram, então, homogeneizadas em Vortex ${ }^{\circledR}$ e, em seguida, centrifugadas $\left(1200 \mathrm{~g}\right.$ por $15 \mathrm{~min}$ a $\left.4^{\circ} \mathrm{C}\right)$. Após a centrifugação, a fase aquosa transparente superior foi retirada cuidadosamente de cada amostra, transferindo-as a outros tubos aos quais adicionamos $500 \mu \mathrm{L}$ de isopropanol gelado. As amostras foram deixadas em descanso para a precipitação do material, em temperatura ambiente, por 15 minutos. Após este período, o material foi centrifugado, nas mesmas condições citadas anteriormente, sendo o sobrenadante descartado. O pellet formado foi lavado em etanol $70 \%$ e submetido a 
nova centrifugação. O sobrenadante foi descartado e o pellet ressuspenso em $15 \mu \mathrm{L}$ de água livre de RNase. As amostras de RNA obtidas foram congeladas em freezer $80^{\circ} \mathrm{C}$ para uso posterior.

O RNA total obtido das amostras foi quantificado por espectrofotometria em um aparelho Nanovue Plus ${ }^{\circledR}$ (General Eletronics, Little Chalfont, BKM, UK) no comprimento de onda de $260 \mathrm{~nm}$, utilizando equivalência de $40 \mu \mathrm{g} / \mathrm{mL}$ para 1 unidade de absorbância. O grau de pureza das amostras foi avaliado através da razão 260/280nm, sendo considerada uma boa extração aquela com valores entre 1,6 e 1,8 .

\subsubsection{PCR em Tempo Real}

A técnica de PCR quantitativo em tempo real (Real time $P C R$ ) foi utilizada para análise da expressão dos genes em estudo. A transcrição reversa do RNA em cDNA foi realizada utilizando-se $1 \mu \mathrm{g}$ de RNA para cada reação, por meio do kit comercial High Capacity cDNA Archive ${ }^{\circledR}$ (Applied Biosystems, Foster City, CA, EUA), seguindo as instruções do fabricante. As amostras de cDNA resultantes desta reação foram diluídas para concentração final de $10 \mathrm{ng} / \mu \mathrm{L}$ em água livre de nucleases (Promega, Madison, WI, EUA), para então serem utilizadas nas análises de expressão gênica.

Para a avaliação das variantes de DIDO, AURKA e GID8 foi utilizado o Power SYBR® Green PCR Master Mix (Applied Biosystems), em conjunto com os primers de qPCR desenhados (Tabela 2, sessão 3.2). As análises de expressão gênica de E2F1 e MIR17HG, foram realizadas por meio das sondas HS00153451 e HS01382425_m1, respectivamente, utilizado o TaqMan® Universal PCR Master Mix (Applied Biosystems). A quantificação relativa dos genes selecionados foi realizada utilizando o termociclador CFX96 Real Time System ${ }^{\circledR}$ (BIORAD), utilizando controles endógenos adequados para normalização interna das amostras. Assim, os resultados da PCR em tempo real (Cts) para cada transcrito foram normalizadas para cada amostra, utilizando a expressão do gene endógeno $\beta$-Actina $(\Delta \mathrm{Ct})$. $\mathrm{A}$ eficiência e especificidade dos primers foram determinadas previamente durante a padronização, por meio de curvas de diluição e avaliação da presença de dímeros 
nas curvas de dissociação, respectivamente, de forma a permitir o cálculo da expressão gênica relativa utilizando a fórmula $2^{-\Delta \Delta C T}$ (PFAFFL, 2001).

\subsubsection{Análise estatística}

As análise estatísticas das amostras de pacientes foram realizadas por meio dos testes Kruskal-Wallis seguido do teste de comparação múltipla de Dunn, cabíveis a cada análise não paramétrica. Já, para os ensaios funcionais foram utilizados os testes T de Student e ANOVA com pós-teste de Bonferroni, cabíveis a cada análise paramétrica. Os resultados com valor de $p \leq 0.05$ foram considerados significativos. Tais análises foram realizadas por meio do software GraphPad Prism $5 \circledast$ (GraphPad Software, Inc., San Diego, CA, USA).

\subsection{Análise proteica por "Western Blotting"}

\subsubsection{Extração e quantificação das proteínas}

Foram transfectadas células NTERA-2 em placas de 12 poços segundo o protocolo previamente descrito na sessão 3.5.2. Para tanto, foram utilizados siRNAs alvo específicos contra mRNA de AURKA e mRNA das isoformas de DIDO, assim como miRNAs miméticos da família do cluster miR-17 92.

Após o período de incubação, 72 horas a partir do início da transfecção, o meio de cultura foi retirado e aos poços foram adicionados $30 \mu \mathrm{L}$ de Tampão de Lise, previamente preparado, composto por tampão RIPA, inibidores de proteases e fosfatases, $\mathrm{NaF}$ 0,5M, o-Vanadato $0,001 \mathrm{M}$ e q.s.p. de água. As placas foram mantidas no gelo, para coleta das células com o auxílio do Cell Scraper. Por fim, as células foram transferidas para microtubos de $1,5 \mathrm{~mL}$ os quais foram mantidos em freezer $-20^{\circ} \mathrm{C}$ até a quantificação das proteínas totais, obtida segundo a metodologia de Bradford.

\subsubsection{Preparo dos géis}

Para o preparo do gel de Poliacrilamida 8\%, com o intuito de capturar proteínas acima de $100 \mathrm{KDa}$ foram adicionados à solução $2,3 \mathrm{~mL}$ de água, $1,3 \mathrm{~mL}$ (30\%) do homogeneizado de acrilamida $(29,2 \%$ acrilamida e 0,8\% N,N'-methylenebis-acrylamide), 1,3mL (1.5M) de TRIS (Tris Hydroxymethil aminomethane) (pH 8.8), 
0,05mL $(10 \%)$ de SDS (Sodium dodecyl sulfate), $0,05 \mathrm{~mL}(10 \%)$ de APS (Ammonium persulfate) e $0,002 \mathrm{~mL}$ de TEMED ( $N, N, N^{\prime}, N^{\prime}$-Tetramethylethylenediamine), para um volume final de $5 \mathrm{~mL}$ por placa.

Já, para o preparo do gel de Poliacrilamida $12 \%$, com o intuito de capturar proteínas até $100 \mathrm{KDa}$ foram acrescentados à solução $1,7 \mathrm{~mL}$ de água, $2 \mathrm{~mL}(30 \%)$ do homogeneizado de acrilamida, $1,3 \mathrm{~mL}(1.5 \mathrm{M})$ de TRIS $(\mathrm{pH} 8.8), 0,05 \mathrm{~mL}(10 \%)$ de SDS, $0,05 \mathrm{~mL}(10 \%)$ de APS e $0,002 \mathrm{~mL}$ de TEMED, para um volume final de $5 \mathrm{~mL}$ por placa.

Os géis foram aplicados em suportes de $1 \mathrm{~mm}$ e, em seguida, acrescentados $400 \mu \mathrm{L}$ de isopropanol concentrado para evitar o contato dos géis com o ar, acelerando, dessa forma, a polimerização dos mesmos. Os suportes foram mantidos na posição vertical até completa solidificação dos géis, cujos nivelamentos foram ajustados para zero graus.

Para o preparo do Gel Stack® (de separação) foram acrescentados, para um volume final de $2 \mathrm{~mL}$ por gel de poliacrilamida, $1,4 \mathrm{~mL}$ de água, $0,33 \mathrm{~mL}(30 \%)$ do homogeneizado de acrilamida, $0,25 \mathrm{~mL}(1.0 \mathrm{M})$ de TRIS $(\mathrm{pH} 6.8), 0,02 \mathrm{~mL}(10 \%)$ de SDS, $0,02 \mathrm{~mL}(10 \%)$ de APS e $0,002 \mathrm{~mL}$ de TEMED.

Após a polimerização dos géis, estes foram vertidos, para descarte do isopropanol, acrescidos de $1,8 \mathrm{~mL}$ do $\mathrm{Gel}$ Stack ${ }^{\circledR}$, colocados a eles os pentes e aguardados 40 minutos até completa polimerização, estando os suportes na posição vertical e com nivelamento dos géis em zero graus.

\subsubsection{Aplicação das proteínas nos géis}

Para o preparo das amostras a serem aplicadas, inicialmente, desnaturamos as proteínas em alta temperatura $\left(100^{\circ} \mathrm{C}\right.$ por 5 minutos) seguido de centrifugação $\left(4^{\circ} \mathrm{C}, 13000\right.$ rpm, 5 minutos $)$.

Para o peso molecular de referência, $8 \mu \mathrm{L}$ deste foram misturados a $5 \mu \mathrm{L}$ de solução LB (Low Binding). Já, para as amostras foram calculados os volumes para $50 \mu \mathrm{g}$ por lane de corrida e misturadas com um volume de solução LB dependente do volume de cada amostra.

As amostras foram pipetadas nas lanes do gel estando o mesmo na posição vertical, dentro da cuba e submerso em tampão de corrida. 
A cuba foi mantida de 4 a $8^{\circ}$ Celcius (geladeira) e ligada à fonte em 100 Volts (V) por 10 minutos, até visualização de formação de bolhas, seguida de aumento da voltagem para 115V. A "corrida" seguiu por aproximadamente 2 horas sendo verificado constantemente a altura em que o peso molecular de referência se encontrava.

\subsubsection{Transferência para membrana de nitrocelulose}

Após aproximadamente 2 horas de "corrida" das proteínas no gel 12\%, este e a membrana de nitrocelulose foram mantidos em suportes separados com tampão de transferência por 10 minutos e, em seguida, as proteínas foram transferidas para a membrana por meio de transferidor semi-seco (BIORAD), sendo o gel no transferidor ajustado seguindo a sequência: 4 papéis de filtro umedecidos em tampão de transferência, membrana de nitrocelulose, gel, 4 papéis de filtro umedecidos em tampão de transferência. Os parâmetros do transferidor foram ajustados para 40 minutos de transferência, com $1 \mathrm{~mm}$ da espessura do gel, 0,3A e $25 \mathrm{~V}$.

Já, para as proteínas no gel $8 \%$, após aproximadamente 2 horas de "corrida", o gel e a membrana de nitrocelulose foram mantidos em suportes separados com tampão de transferência por 10 minutos e, em seguida, as proteínas foram transferidas para a membrana por meio de transferidor submerso "submarino" sendo o gel no suporte de transferência "sanduíche" ajustado seguindo a sequência: scotch brite, 2 papéis de filtro umedecidos em tampão de transferência, membrana de nitrocelulose, gel, 2 papéis de filtro umedecidos em tampão de transferência, scotch brite. O suporte foi colocado dentro da cuba, submerso em tampão de transferência para imersão, e os parâmetros de transferência, como o tempo de transferência, foram ajustados para over night; $30 \mathrm{~V} ; 4$ a $8^{\circ} \mathrm{Celcius}$ (geladeira).

\subsubsection{Marcação com anticorpos}

A membrana de nitrocelulose foi incubada com uma solução de bloqueio (BSA ou leite) por 1 hora em agitação e à temperatura ambiente, seguida de descarte da solução de bloqueio e acréscimo do anticorpo (ab) primário, este diluído em tampão TBST. A mesma foi incubada, posteriormente, over night, em geladeira e 
sob leve agitação. $O$ anticorpo primário foi, então, coletado com pipeta por ser reutilizável, acrescentando a ele solução antifúngica contendo $0,1 \%$ azida, homogeneizado e armazenado em geladeira, e a membrana lavada 3 vezes com tampão TBST, com duração de 5 minutos cada lavagem.

O tampão TBST foi descartado e, em seguida, acrescido à membrana o anticorpo secundário diluído em TBST (1:3000). A membrana foi mantida sob leve agitação em temperatura ambiente, por 1 hora. Por fim, o anticorpo secundário foi descartado e a membrana lavada 3 vezes com tampão TBST, com duração de 5 minutos cada lavagem.

\subsubsection{Aquisição das imagens}

Após secagem da membrana com papel de filtro, a ela foi acrescido o reagente ECL Prime ${ }^{\circledR}$ (Enhanced Chemiluminescence Prime) (ou ECL Normal®) (Amersham) sobre a superfície, por 2 minutos, sendo calculados aproximadamente $700 \mu \mathrm{L}$ do reagente para uma membrana contendo 9 lanes.

A membrana passou, novamente, por secagem da superfície com papel de filtro e foi, por fim, levada para exposição no foto-documentador (Image Quant $350 \AA$, $\mathrm{GE}$ ), sendo os parâmetros do aparelho ajustados da seguinte forma para captura das imagens: Stack Frames (total frames $=50)($ exposure time $=30$ seconds), sensitivity/ resolution (medium/medium).

A análise quantitativa das imagens foi realizada por meio do software Image ${ }^{\circledR}$, o qual quantifica a intensidade dos pixels de cada banda proteica, adquirida na imagem pelo foto-documentador, e as transpõem em formato de gráficos sigmoides. As áreas sob os picos são, então, calculadas e plotadas em gráficos em barra. 


\subsection{Estrutura gênica do locus DIDO e de suas variantes}

\subsubsection{Splicing alternativo}

As três isoformas proteicas oriundas do locus DIDO (DIDO1, DIDO2 e DIDO3; ou isoformas $\mathrm{a}, \mathrm{b}$ e c, respectivamente) derivam de variantes transcricionais geradas por splicing alternativo (Figura 7). A variante DIDO1 é a menor, sendo composta por apenas 6 exons que codificam 562 aminoácidos (aa). Os 6 primeiros exons são compartilhados pelas outras duas variantes, no entanto, o exon 6 em DIDO1 se estende na região $3^{\prime}$. A variante DIDO2 de tamanho intermediário (codificando 1189 aa) possui 9 exons adicionais, totalizando 15 exons. Estes 9 exons são compartilhados com a variante mais longa DIDO3, no entanto, o exon 15 em DIDO2 também se estende na região $3^{`}$. A variante mais longa DIDO3 (codificando 2240 aa) possui um $16^{\circ}$ exon adicional.

\subsubsection{Promotores alternativos}

Ao avaliarmos as bases de dados em busca das sequências de referência (RefSeqs) dos transcritos alternativos de DIDO, identificamos que cada uma das isoformas proteicas de DIDO, podem ser traduzidas a partir de dois transcritos, derivados de promotores alternativos. Assim, DIDO1 pode ser traduzido a partir das variantes 1 e 2 ( $v 1$ e v2), transcritas a partir de um promotor alternativo distal e outro proximal, respectivamente. O mesmo ocorre para DIDO2 (v3 e v6) e DIDO3 (v4 e v5) (Tabela 1 e Figura 7).

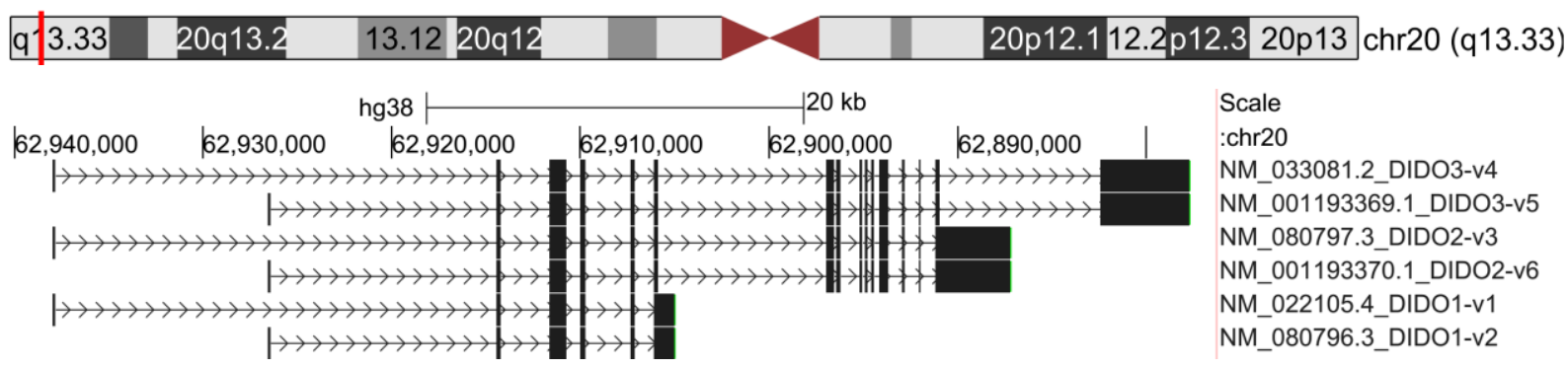

FIGURA 7. Posição e organização gênica do locus DIDO e suas variantes. As sequências de referência (RefSeqs, NM_) originadas do locus do gene DIDO foram identificadas no site do NCBI e alinhadas ao genoma utilizando a ferramenta online BLAT (UCSC Genome Browser). As três variantes DIDO1, DIDO2 e DIDO3, originadas por splicing alternativo, podem ser transcritas a partir 
de dois promotores alternativos, um distal ( $\mathrm{v} 1, \mathrm{v} 3$ e v4 para DIDO 1, 2 e 3, respectivamente) e um proximal (v2, v6 e v5 para DIDO 1, 2 e 3, respectivamente).

\subsection{3. $O$ gene GID8}

Ao avaliarmos a estrutura gênica do gene DIDO, assim como as regiões regulatórias associadas, identificamos que o promotor distal de DIDO era compartilhado com um locus responsável por um transcrito codificando uma orf predita de 228 aminoácidos (aa), denominada C20orf11 (chromosome 20 open reading frame 11, ou TWA1/GID8 NM_017896.2). O compartilhamento do promotor com DIDO (Figura 8) indica fortemente que as funções de DIDO e TWA1/GID8 sejam inter-relacionadas, uma vez que sua expressão provavelmente ocorreria de forma sincrônica. Com isto em mente, decidimos estender algumas das análises de expressão para o transcrito C20orf11, visando avaliar a possível correlação com os níveis dos transcritos de DIDO.

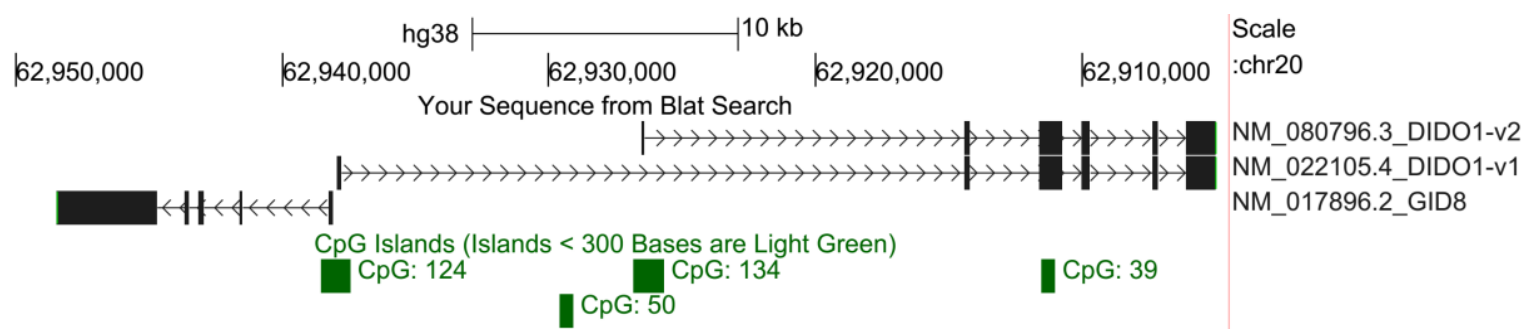

FIGURA 8. Compartilhamento do promotor distal de DIDO com o transcrito GID8. A inspeção do locus de DIDO levou à identificação do gene GID8 o qual compartilha a mesma região promotora das variantes distais de DIDO. Para clareza, apenas as variantes DIDO1 transcritas a partir de ambos os promotores (distal e proximal) são mostradas. As ilhas $\mathrm{CpG}$ são mostradas na figura para ilustrar a presença destes elementos regulatórios nos promotores compartilhados distal e proximal. Figura gerada usando a ferramenta online BLAT (UCSC Genome Browser).

\subsubsection{Identificação de sítios alvos dos microRNAs na 3 '-UTR das variantes de DIDO}

Com o propósito de encontrarmos sítios alvos para microRNAs nos transcritos alternativos de DIDO 1, 2 e 3 , a base de dados microrna.org foi utilizada. Notoriamente, todas as três variantes apresentavam inúmeros sítios preditos para microRNAs conhecidamente expressos a partir de uma unidade transcricional única, o cluster miR-17 92 (Figura 9). Foram identificados potenciais sítios alvos para 
miRNAs da família miR-17 (incluindo miRs-17* e miR-20a, do cluster miR-17 92, e miR-106a e -340).

Ainda, após análise dos possíveis sítios de ligação entre os microRNAs do cluster miR-17 92 e variantes transcricionais de DIDO, foram encontrados sítios preditos em DIDO1 para os miR-18a e miR-92a, enquanto que em DIDO2 foram identificados sítios para os miR-18a, miR-19a e miR-20a. Já, DIDO3 apresentou sítios para os miR-18a e miR-20a.
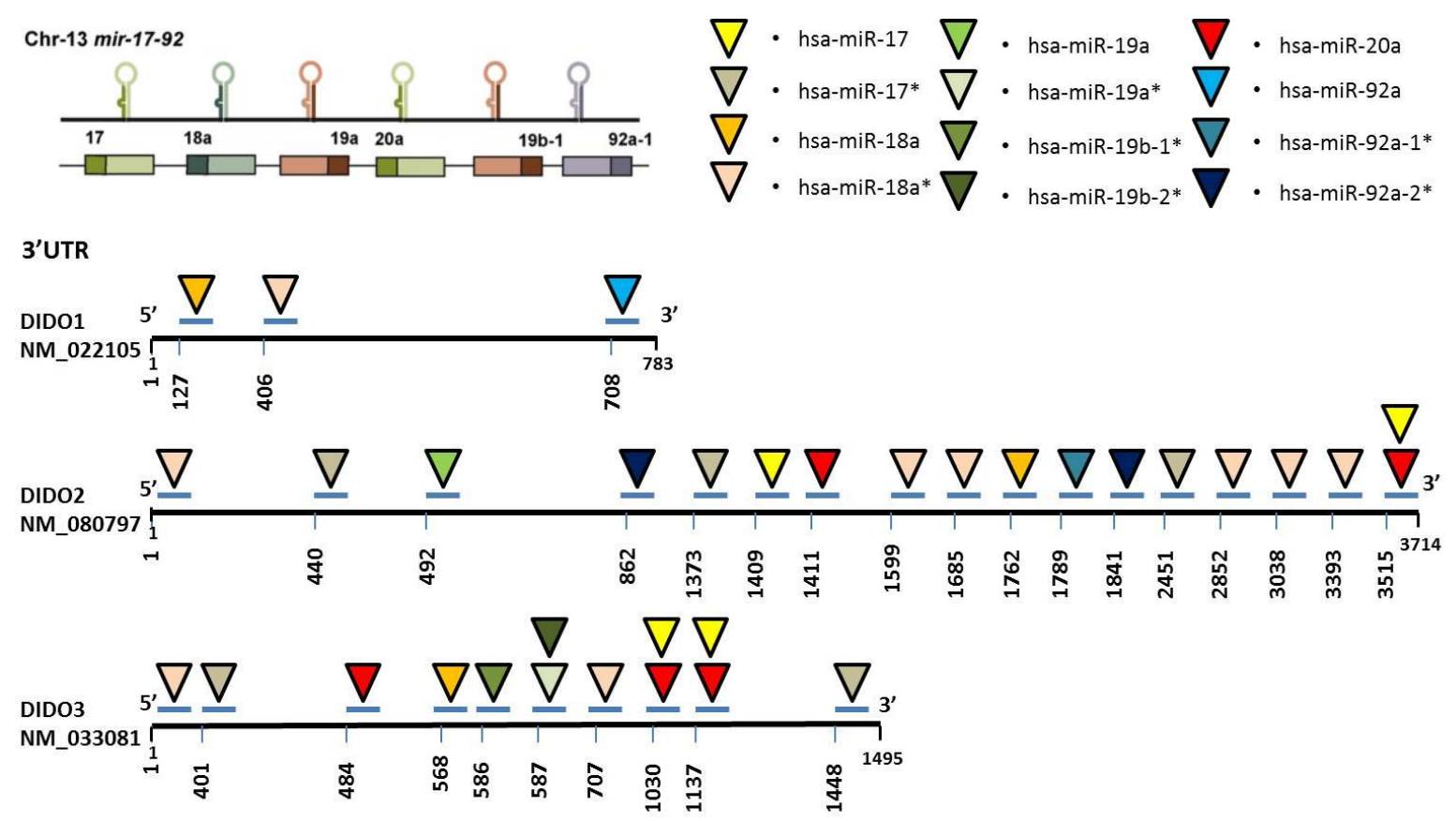

FIGURA 9. Sítios alvos preditos dos microrRNAs do cluster 17 92 na região 3 '-UTR das variantes de DIDO. Os identificadores RefSeq dos três transcritos alternativos de DIDO foram utilizados para uma busca no banco de dados online (microrna.org). A posição relativa de cada microRNA foi utilizada para gerar um esquema dos sítios de interesse. $O$ esquema do cluster mir17 92 aparece no topo à esquerda.

\subsection{Expressão de DIDO em amostras de doenças hematológicas}

Apesar do compartilhamento da maioria dos exons entre as variantes, as extensões nas regiões 3` do exon 6 em DIDO1, do exon 15 em DIDO2, e do exon 16 exclusivo de DIDO3, conferem uma região específica a cada um destes transcritos alternativos, permitindo o desenho de pares de primers específicos para as três variantes de DIDO. Assim, a fim de quantificar todas as três variantes, foram 
desenhados primers nos dois últimos exons de cada transcrito, com os primers reversos desenhados nas regiões $3^{\prime}$ específicas de cada variante. Esta estratégia nos permitiu a detecção e quantificação específica das 3 variantes, além de evitarmos a amplificação de DNA contaminante potencialmente presente nas amostras de RNA (Figura 10).

Como cada uma das variantes de splicing de DIDO (1, 2 e 3) pode ser transcrita a partir de um promotor alternativo, pares de primers específicos para a região 5' UTR foram desenhados na tentativa de identificar qual promotor seria responsável pela transcrição das variantes identificadas. Na figura 10 é possível visualizar a região $5^{`}$ amplificada pelos primers desenhados para identificar as variantes 1 , 3 e 4, transcritas a partir do promotor distal (DIDO PD-v134); bem como a região amplificada pelos primers desenhados para identificar as variantes 2, 6 e 5, transcritas a partir do promotor proximal (DIDO PP-v265).

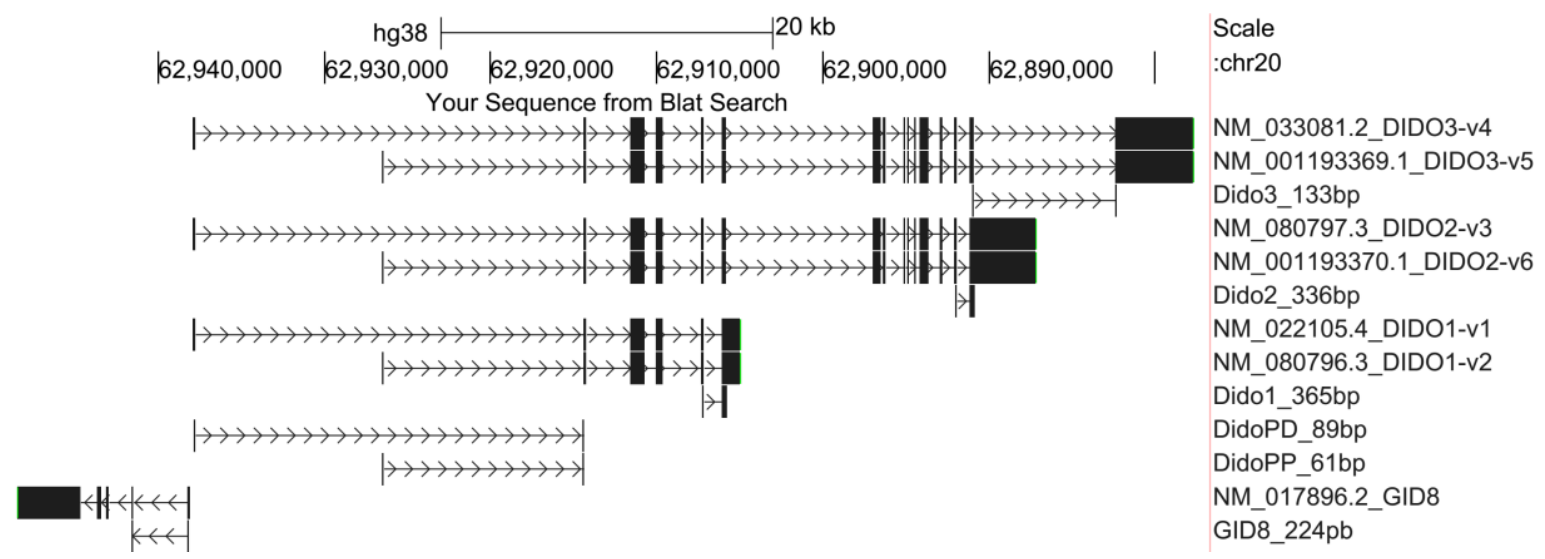

FIGURA 10. Alinhamento dos amplicons esperados com os primers de qPCR desenhados. Os amplicons (esperados para os primers de qPCR desenhados para quantificar as variantes de DIDO1, 2 e 3, assim como GID8, estão indicados na figura, seguidos do tamanho esperado em pares de bases. As sequências dos mesmos foram alinhadas com as sequências de referência (RefSeqs, NM_) originadas do locus do gene DIDO utilizando a ferramenta online Blat (UCSC Genome Browser). As três variantes DIDO1, DIDO2 E DIDO3, originadas por splicing alternativo, podem ser transcritas a partir de dois promotores alternativos, um distal (PD, comum às variantes $v 1$, v3 e v4 para DIDO 1, 2 e 3, respectivamente) e um proximal (PP, comum às variantes v2, v6 e v5 para DIDO 1,2 e 3 , respectivamente).

A fim de avaliarmos a potencial relação entre alterações nos níveis de DIDO com diferentes tipos de doenças hematológicas, os níveis de expressão das 
variantes transcricionais de DIDO provenientes de amostras com alterações hematológicas foram comparados com amostras controle, ou seja, amostras oriundas do sangue periférico (SP) ou de células mononucleares da medula óssea (MO) (Figura 11). Paralelamente, a utilização de primers próprios do promotor distal de DIDO para análise de expressão das três variantes consecutivas, assim como, a utilização de primers específicos para análise de expressão de GID8, também, foram avaliadas nas mesmas amostras. A análise revelou que as amostras de SP e MO não diferiram significativamente, quanto ao nível de quaisquer dos transcritos avaliados, embora os níveis de DIDO1 tenham se apresentado mais altos em SP, em comparação a MO (o oposto observado para DIDO2).

As amostras de pacientes com SMD (independente da presença de alterações cariótipicas), apresentaram níveis de expressão de DIDO1, DIDO2 e DIDO3 significativamente menores que os observados nas amostras controle de SP e MO (neste caso, não significante para DIDO1), bem como em relação aos níveis nas amostras de LLC (Kruskal-Wallis seguido do teste de comparação múltipla de Dunn); sendo que os níveis mais reduzidos foram os de DIDO3 (Figura 11). Similarmente, os níveis de expressão de GID8, para as mesmas amostras de SMD, mostraram-se semelhantes aos de DIDO1. Estes resultados revelaram-se em linha com resultados preliminares obtidos pelo grupo espanhol (FUTTERER et al., 2005), corroborando a associação de níveis reduzidos de DIDO com as síndromes mielodisplásicas. 

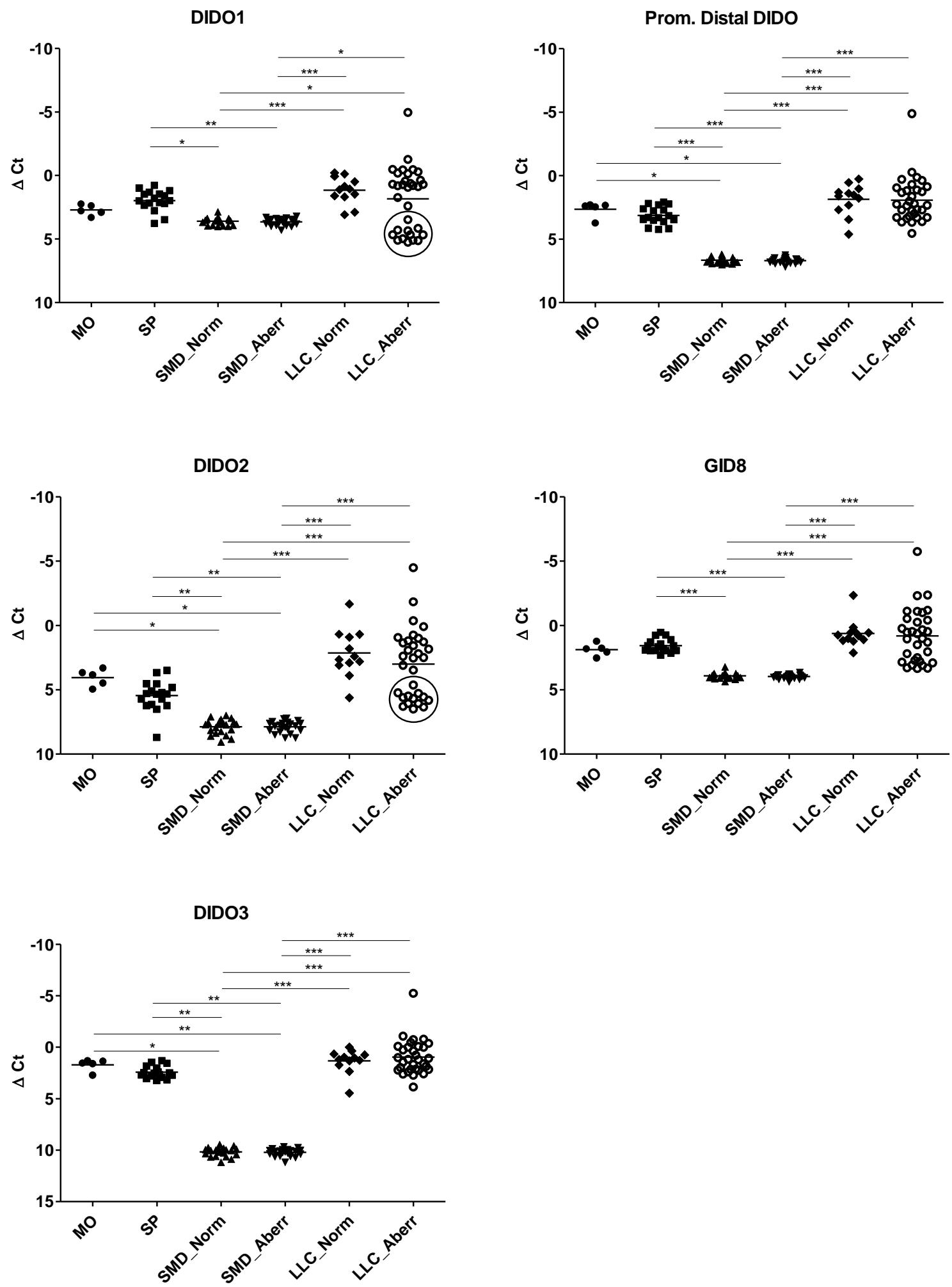

FIGURA 11. qPCR dos transcritos de DIDO e GID8 avaliados em amostras de pacientes com doenças hematológicas. Níveis transcricionais de todas as variantes de DIDO determinadas por 
qPCR. Valores no eixo y correspondem a diferença entre o $\mathrm{Ct}$ do transcrito e o $\mathrm{Ct}$ obtido pelo gene controle GAPDH. O eixo y apresenta-se invertido para melhor compreensão, ou seja, com os menores valores de $\triangle \mathrm{Ct}$ correspondendo aos maiores valores de expressão. MO (Medula Óssea); SP (Sangue Periférico); SMD_Norm (síndrome mielodisplásica com cariótipo normal); SMD_Aberr (síndrome mielodisplásica com cariótipo alterado); LLC_Norm (LLC) (leucemia linfoide crônica com cariótipo normal); LLC_Aberr (LLC) (leucemia linfoide crônica com cariótipo alterado). ${ }^{*} 0.01<p<$ $0.05 ;{ }^{* *} 0.001<\mathrm{p}<0.01 ;{ }^{* * *} \mathrm{p}<0.001$.

Apesar dos níveis extremamente baixos nas amostras de SMD, não houve diferenças dos níveis de expressão de DIDO entre o grupo de SMDs com cariótipo normal (SMD_Norm) e o grupo com alterações cariotípicas (SMD_Aberr), revelando, para tais amostras, uma aparente falta de associação entre a baixa expressão de DIDO e a presença de instabilidade cromossômica.

Avaliando os resultados provenientes das amostras de LLC é possível observar que, enquanto os níveis de expressão de DIDO em amostras de LLC sem alterações cariotípicas (LLC_Norm) se mostram relativamente homogêneos para todos os transcritos, para as amostras com aberrações cariotípicas (LLC_Aberr) nota-se uma distribuição nitidamente bimodal para DIDO1 e DIDO2 e, aparentemente, para GID8 (Figura 11). Ainda, a distribuição das amostras de LLC_Aberr com níveis elevados para DIDO1 se assemelha à distribuição das amostras de LLC com cariótipo normal (LLC_Norm). Em contraste, o outro subgrupo de LLC_Aberr apresentou níveis bem inferiores, inferiores até mesmo aos níveis de DIDO1 observados para as amostras de SMD (Figura 11).

\subsection{Identificação das características associadas aos subgrupos de LLC com expressão distinta de DIDO}

A fim de investigarmos se as sub-populações de LLC portando aberrações cromossômicas (identificadas com base nos níveis de DIDO) poderiam estar associadas a diferenças clínico-laboratoriais, subdividimos estas amostras visualmente com base na distribuição de DIDO1 e DIDO2, e de acordo com um cutoff para DIDO3, estipulado com base na média da distribuição.

Os dois sub-grupos foram, então, comparados para identificação de potenciais diferenças nos parâmetros clínico-laboratoriais disponíveis (Tabela 6 da sessão 7 de Anexos). Surpreendentemente, tanto a contagem de leucócitos como o número de cromossomos foram significativamente maiores (teste bicaudal de Mann 
Whitney) nas amostras com menores níveis de expressão de DIDO1 ou DIDO2 (Figura 12). Mais especificamente, dentre as amostras de LLC com alterações cromossômicas, aquelas com níveis elevados de expressão de DIDO apresentaram, em média, número de cromossomos próximos de uma ploidia normal, enquanto, o subgrupo com expressão baixa de DIDO apresentou ganhos cromossomais na maioria absoluta dos casos.

Digno de nota, ao avaliarmos uma possível associação dos níveis de DIDO com ganhos cromossomais, nas amostras de SMD, não identificamos nenhum indício (Figura 38 da sessão 7 do Anexo). 
LLC_Aberr

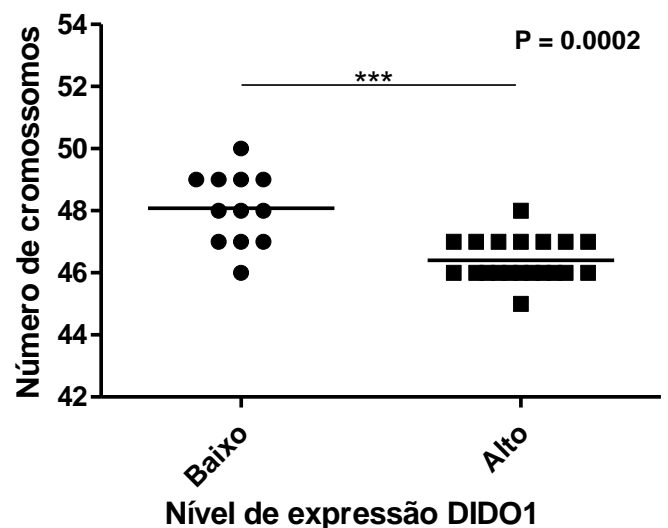

LLC_Aberr

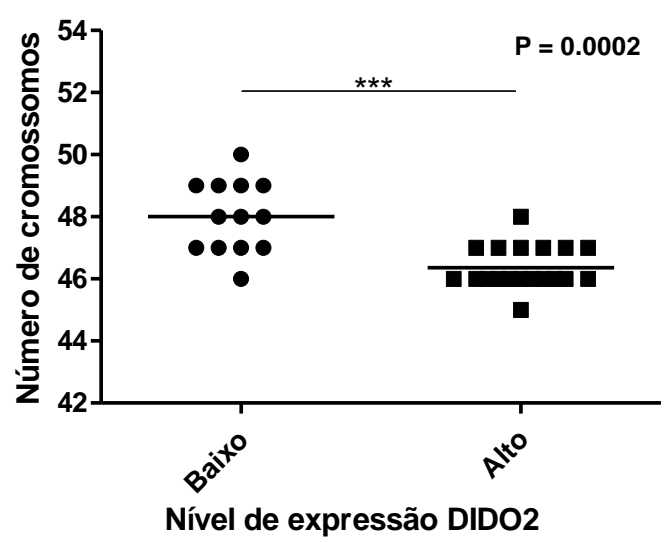

LLC_Aberr

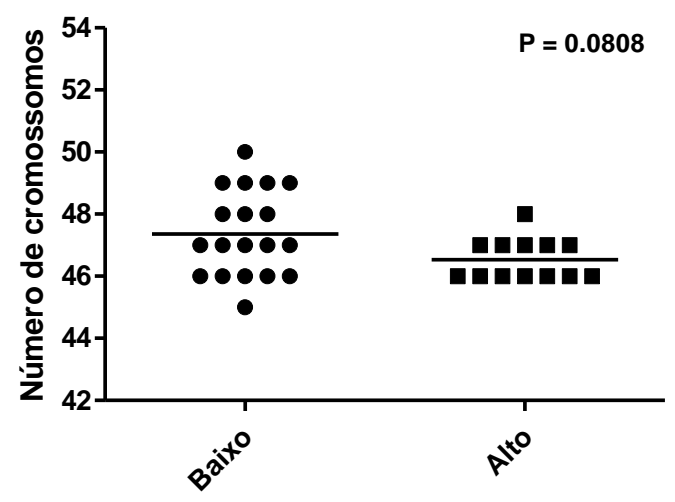

Nível de expressão DIDO3
LLC Aberr

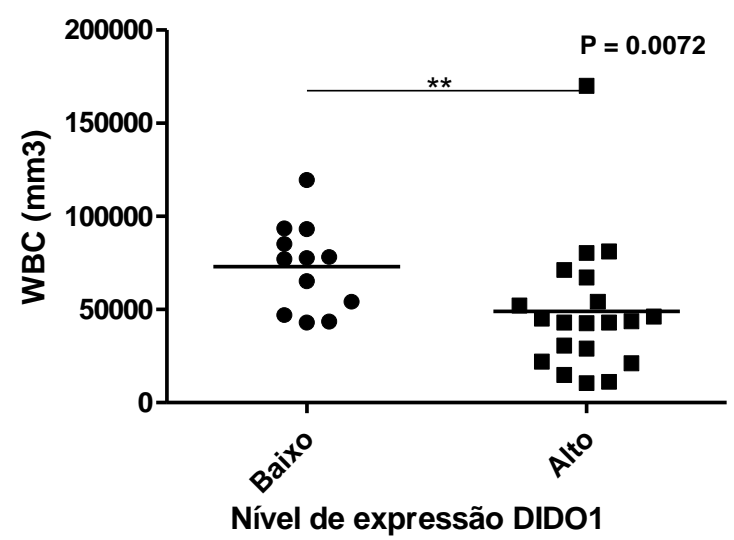

LLC_Aberr

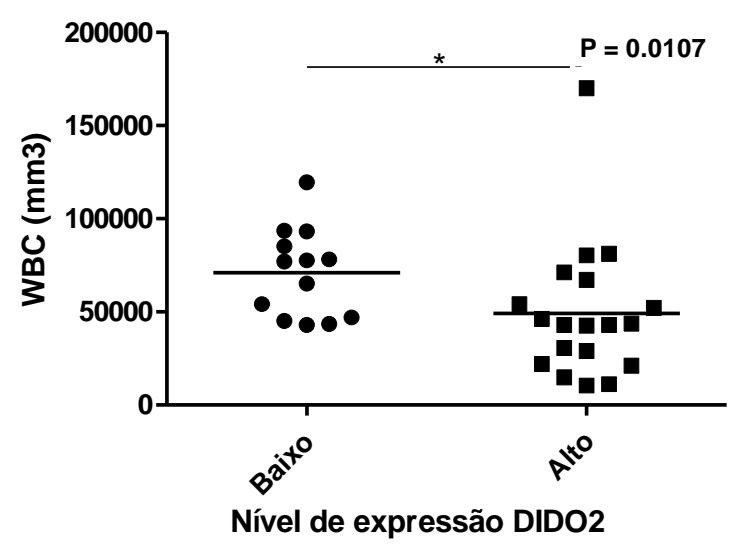

LLC_Aberr

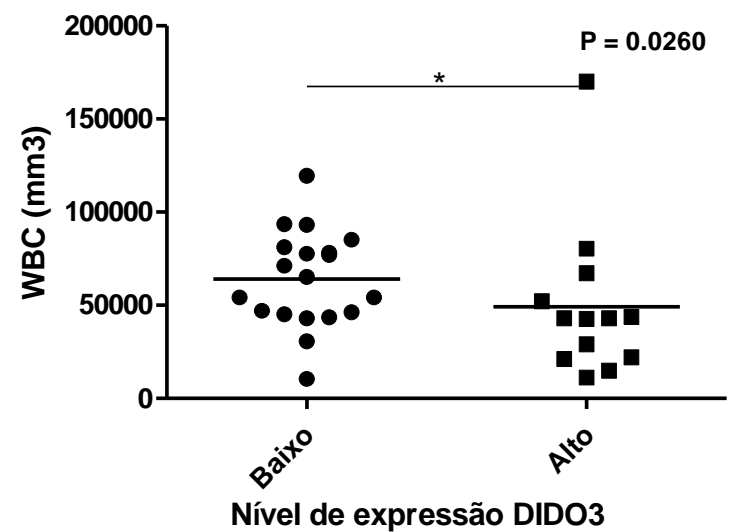

FIGURA 12. Associação entre níveis de DIDO e características clínico-laboratoriais. As amostras de LLC com alterações cromossômicas foram separadas com base nos níveis de DIDO e comparadas quanto à contagem de células brancas do sangue (WBC) e do número total de cromossomos, na análise do cariótipo. ${ }^{*} 0.01<p<0.05 ;{ }^{* *} 0.001<p<0.01 ;{ }^{* * *} p<0.001$. 


\subsection{Expressão de AURKs em amostras de doenças hematológicas}

Tendo em vista a importância das Aurora-quinases nos processos relacionados à manutenção da integridade genômica e a associação estabelecida entre sua superexpressão e a instabilidade cromossômica em diversas neoplasias, avaliamos a expressão de AURKA e AURKB no mesmo grupo de neoplasias hematológicas, visando identificar, especificamente, se tais níveis de expressão (no caso, níveis elevados) também estariam associados com maiores contagens de glóbulos brancos e com ganhos cromossomais.

Nas amostras de SMD, mais uma vez, não houve diferença significativa entre as amostras com citogenética normal e citogenética aberrante; entretanto, assim como o observado para DIDO, no grupo de amostras de LLC com citogenética aberrante duas subpopulações com níveis de expressão claramente distintos foram observados entre si. Ainda, enquanto um dos grupos demonstrou uma distribuição dos níveis das AURKs similar ao grupo de LLCs sem alterações citogenéticas, o outro grupo apresentou elevados níveis de expressão para estes transcritos.

Similarmente às análises descritas para DIDO, tais amostras foram subdivididas de acordo com o nível de expressão das AURKs e comparadas quanto ao número de cromossomos totais e contagem de glóbulos brancos. As análises revelaram que amostras com níveis elevados das AURKs estão associadas de forma estatisticamente significativa com ganhos cromossomais e contagens elevadas de glóbulos brancos (Figura 13). 

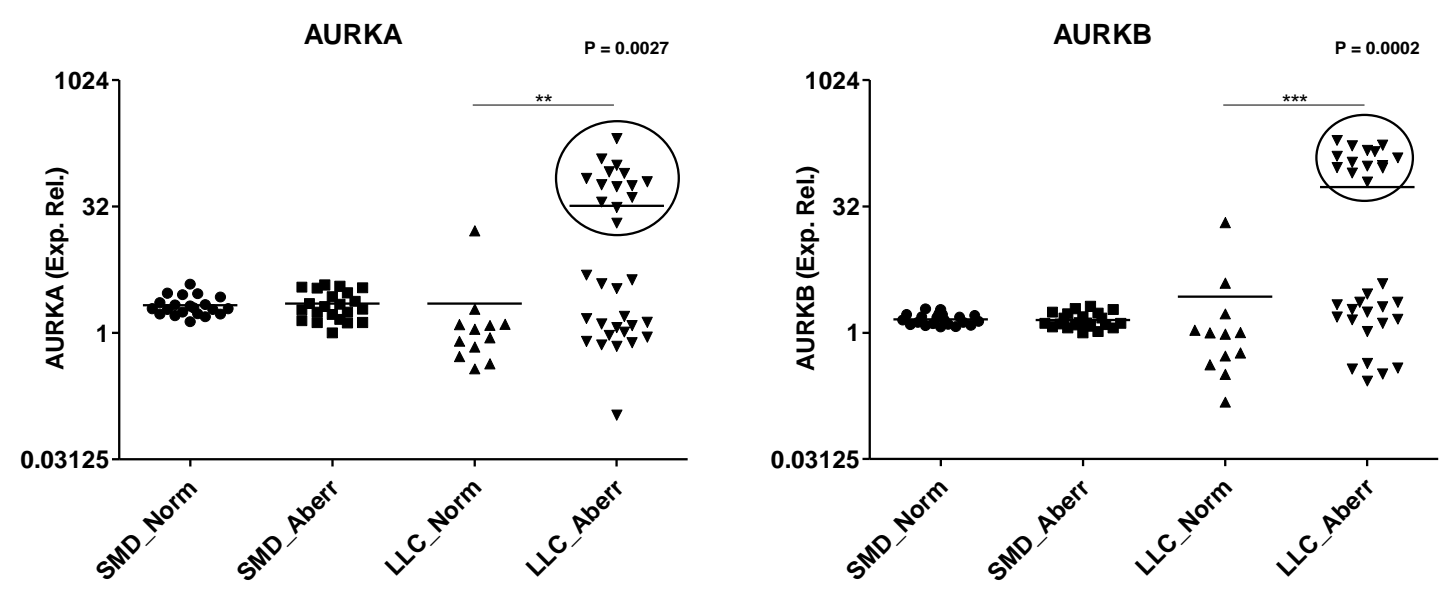

LLC_Aberr

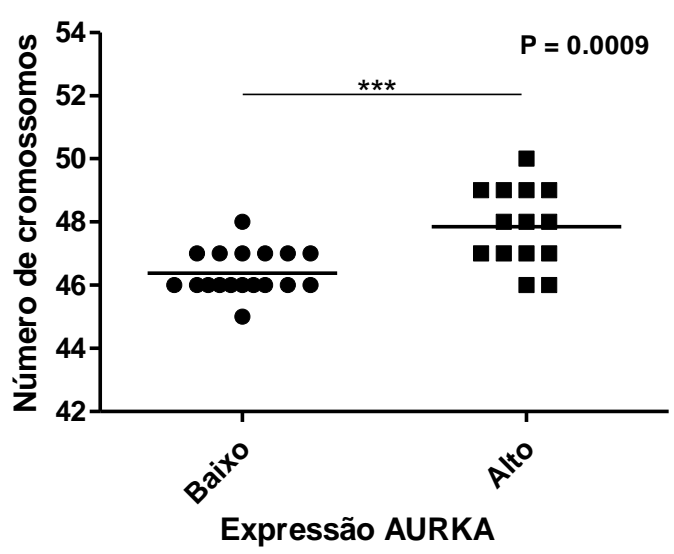

LLC_Aberr

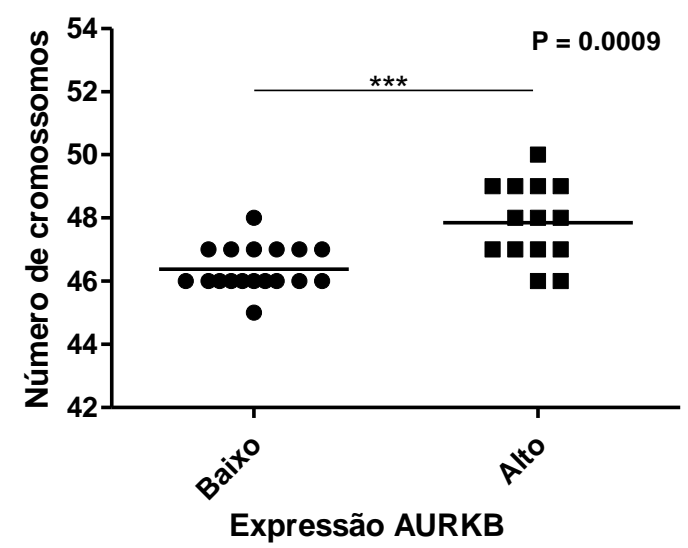

LLC_Aberr
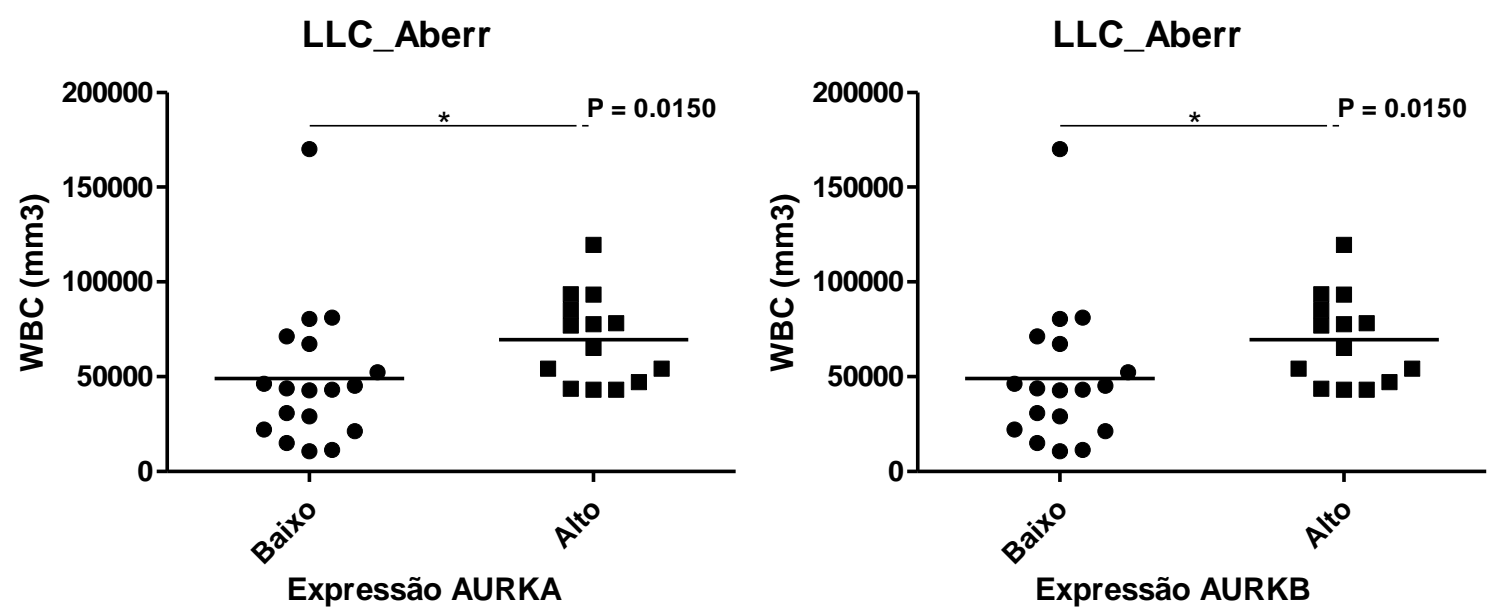

FIGURA 13. Expressão de AURKA e AURKB em amostras de pacientes com doenças hematológicas e análise comparativa do número de cromossomos e WBC entre grupos de LLC aberrante (LLC_Aberr) que expressam níveis elevados ou baixos de AURKs. Altos níveis de 
expressão de AURKs estão associados à instabilidade cromossômica. Níveis transcricionais das AURKs determinados por qPCR. ${ }^{*} 0.01<p<0.05 ;{ }^{* *} 0.001<p<0.01 ;{ }^{* * *} p<0.001$.

\subsection{Relação entre os níveis de expressão das variantes transcricionais de DIDO e AURKs, em amostras de pacientes com LLC aberrante}

Tendo em vista a associação observada entre níveis baixos de DIDO ou altos de AURK com ganhos cromossomais e contagem elevada de glóbulos brancos, os subgrupos de amostras com níveis de expressão opostos de DIDO1, DIDO2 ou DIDO3 foram comparados entre si quanto à expressão de AURKA e AURKB. Interessantemente, esta análise demonstrou claramente que as mesmas amostras que possuem baixa expressão das variantes de DIDO, possuem alta expressão das variantes das AURKs (Figura 14).. 
LLC Aberr

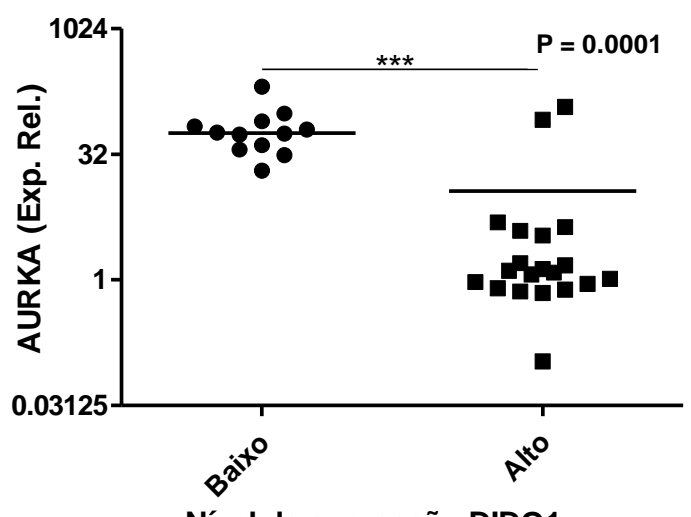

Nível de expressão DIDO1

LLC_Aberr

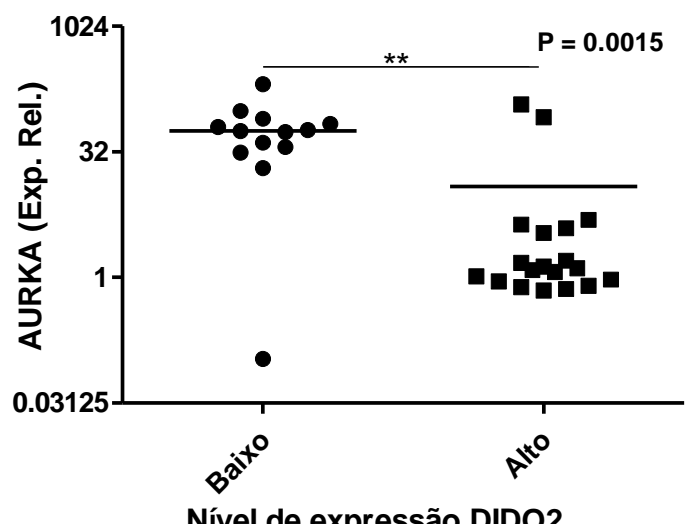

Nível de expressão DIDO2

LLC_Aberr

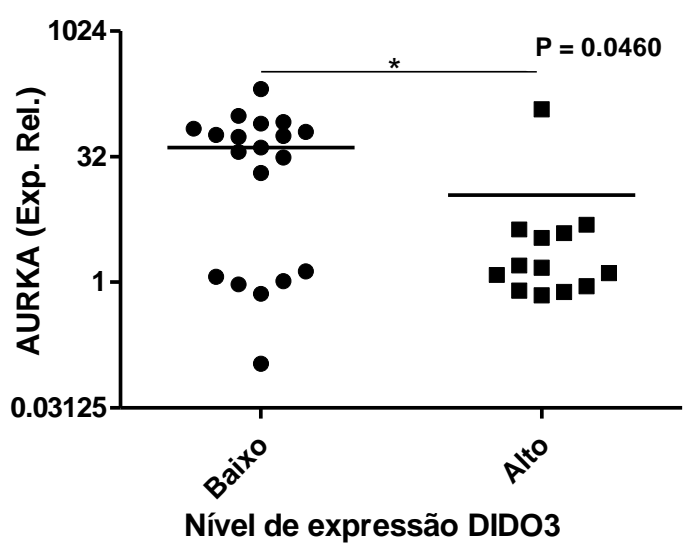

LLC Aberr

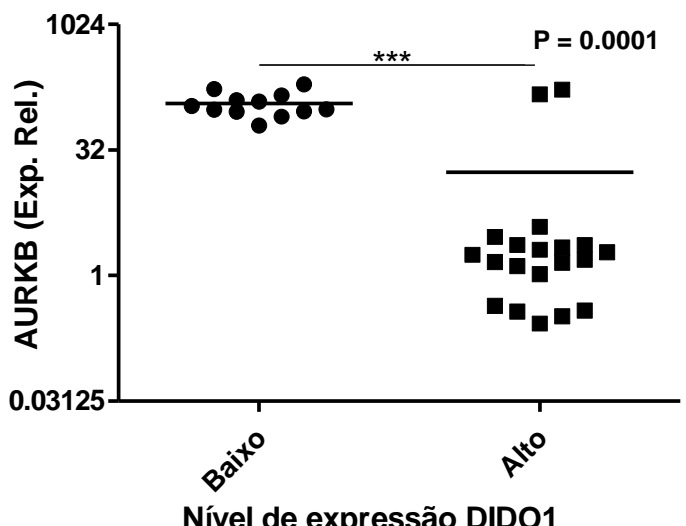

LLC_Aberr

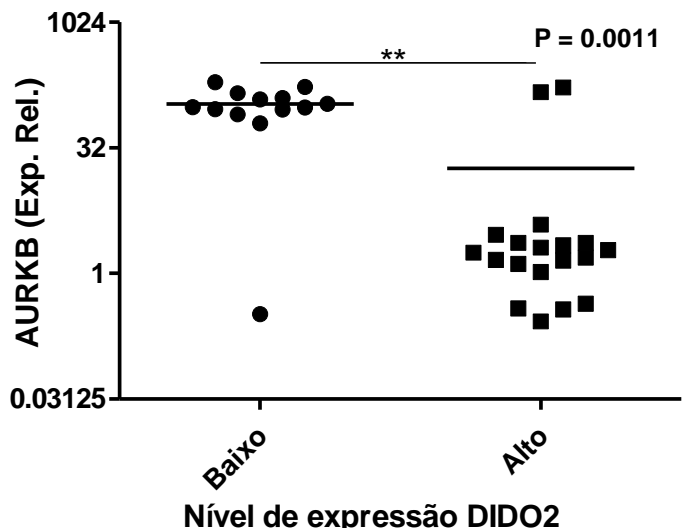

LLC_Aberr

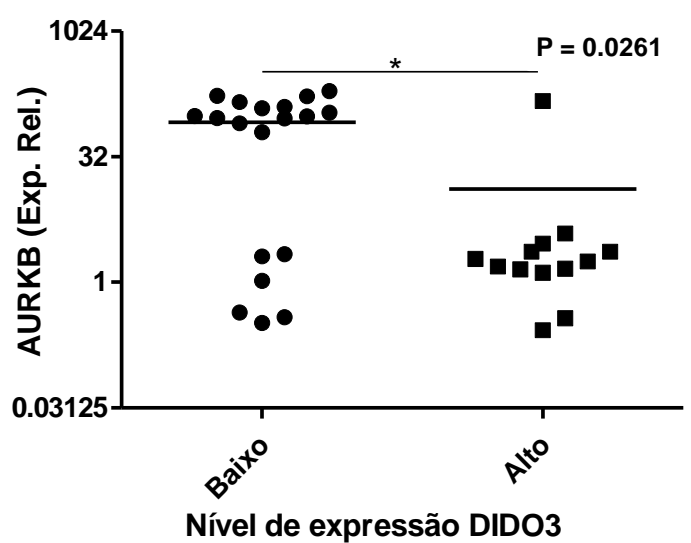

FIGURA 14. Análise comparativa da expressão de AURKA e AURKB entre grupos de LLC aberrante (LLC_Aberr) que expressam níveis elevados ou baixos de DIDO. Níveis transcricionais das AURKs determinados por qPCR. Baixos níveis de expressão de DIDO estão associados a um 
pior prognóstico, assim como a maior propensão à aneuploidias e altas taxas de WBC. Da mesma forma, altos níveis de AURKs estão associados à instabilidade cromossômica. * $0.01<p<0.05$; ** $0.001<p<0.01 ;{ }^{* * *} p<0.001$.

\subsection{Potencial mecanismo regulatório envolvendo E2F1 e MIR17HG, mediando os níveis opostos entre AURK e DIDO}

Visando identificar potenciais mecanismos regulatórios que explicassem os níveis opostos entre as AURKs e as variantes de DIDO, voltamos nossa atenção para a literatura científica. Interessantemente, de acordo com He e colaboradores (2010), a AURKA é capaz de induzir indiretamente a transcrição do cluster miR17 92 (MIR17HG), por meio do aumento de disponibilidade do fator de transcrição E2F1 (HE et al., 2010). Importantemente, ao investigarmos a existência de sítios alvo dos microRNAs do cluster miR-17 92 nas variantes de DIDO (Figura 9, sessão 4.1.4), identificamos que todas as três variantes apresentavam inúmeros sítios preditos para microRNAs deste cluster. Assim, decidimos avaliar os níveis dos transcritos potencialmente envolvidos nesta via (E2F1 e MIR17HG) nas amostras de LLC com aberrações cromossômicas (Figura 15).

Interessantemente, ao avaliarmos os níveis de E2F1 e MIR17HG nos subgrupos definidos pelos níveis de expressão de DIDO, ambos revelaram-se inversamente relacionados aos níveis de expressão das variantes de DIDO, com as amostras com baixos níveis de DIDO apresentado níveis significativamente elevados para E2F1 (Figura 15). Ainda, apesar dos níveis de MIR17HG não estarem significativamente mais altos no grupo com baixa expressão de DIDO, pode ser visto claramente que, para as amostras com baixos níveis de DIDO1 ou DIDO2, a expressão de MIR17HG é estritamente controlada sendo mantida numa faixa com níveis acima da maioria das amostras do grupo com níveis de DIDO normais (iguais aos controles ou às amostras sem alterações citogenéticas). 
LLC Aberr

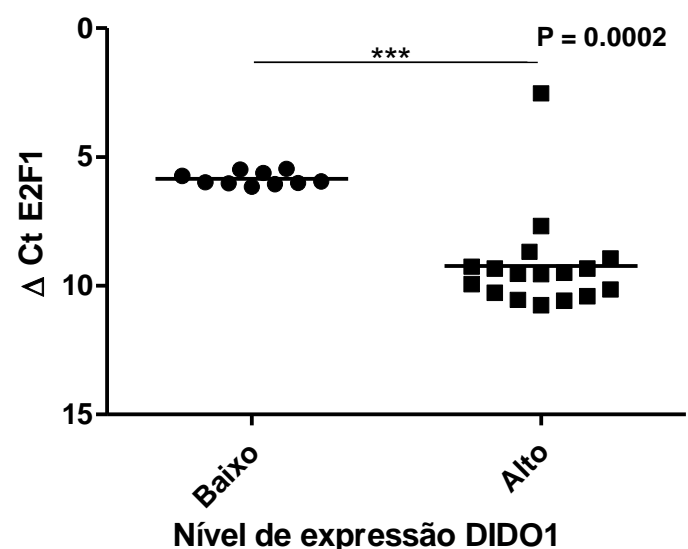

LLC_Aberr

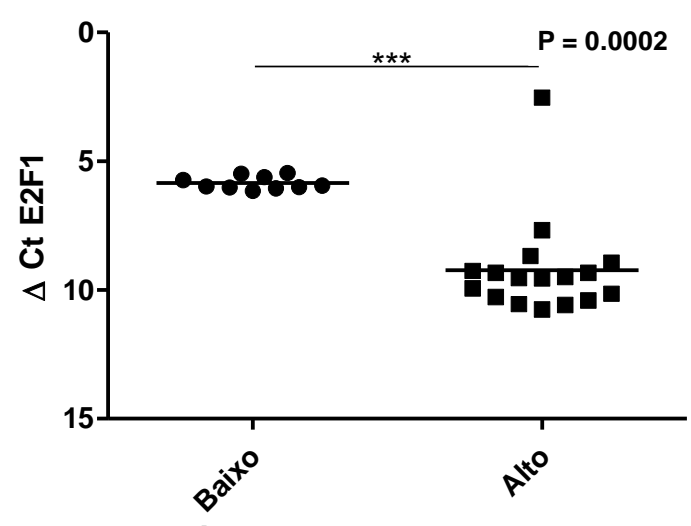

Nível de expressão DIDO2

LLC_Aberr

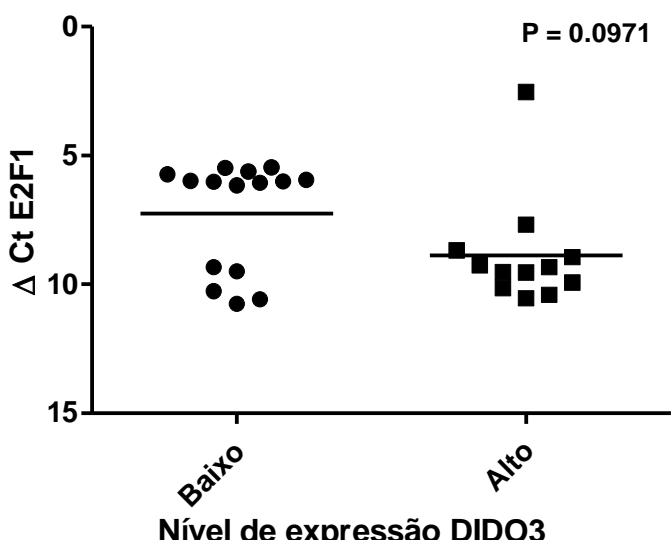

LLC_Aberr

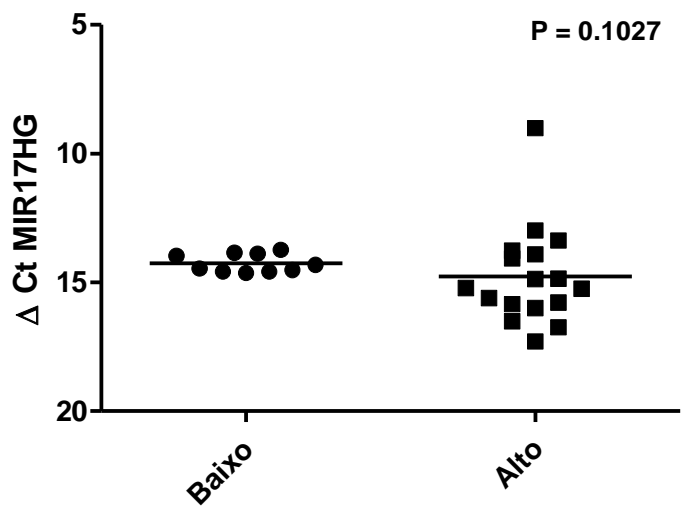

Nível de expressão DIDO1

LLC_Aberr

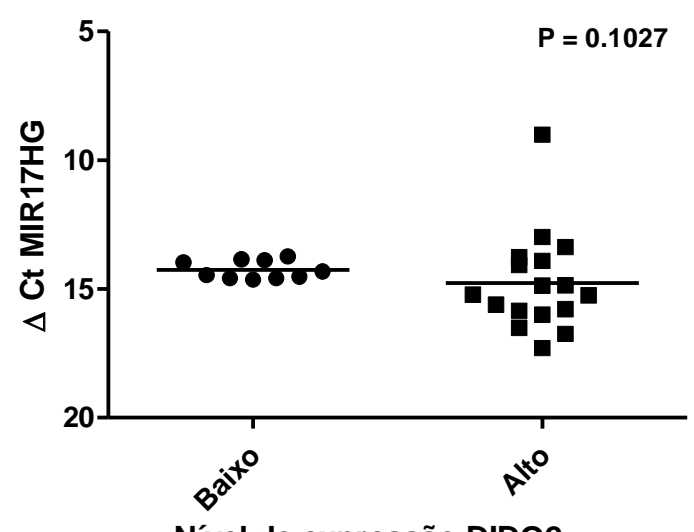

Nível de expressão DIDO2

LLC_Aberr

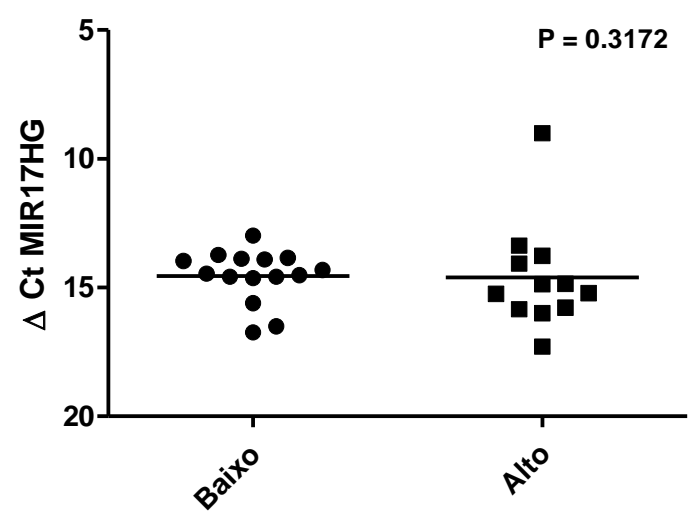

Nível de expressão DIDO3

FIGURA 15. Análise comparativa da expressão de E2F1 e MIR17HG entre grupos de LLC aberrante (LLC_Aberr) que expressam níveis elevados ou baixos de DIDO. Baixos níveis de 
expressão de DIDO estão associados a um pior prognóstico. Níveis transcricionais de E2F1 e MIR17HG determinados por qPCR. Valores no eixo y correspondem a diferença entre o $\mathrm{Ct}$ do transcrito e o $\mathrm{Ct}$ obtido pelo gene controle GAPDH. O eixo y apresenta-se invertido para melhor compreensão, ou seja, com os menores valores de $\Delta \mathrm{Ct}$ correspondendo aos maiores valores de expressão. A relação inversa entre os níveis de DIDO e das AURKs se faz presente, também, nas análises de expressão relativa de E2F1 e MIR17HG para as três variantes transcricionais de DIDO. * $0.01<p<0.05 ;{ }^{* *} 0.001<p<0.01 ;{ }^{* * *} p<0.001$.

\subsection{Regulação de E2F1, MIR17HG e variantes de DIDO via AURKA}

Tendo em vista os indícios da existência de um potencial mecanismo regulatório de AURKA sobre DIDO, mediado pela indução de E2F1 e a consequente indução e ação dos microRNAs do cluster miR-17 92, decidimos avaliar este mecanismo funcionalmente. Para isso, utilizamos células NTERA-2 como modelo experimental e silenciamos os transcritos de AURKA utilizando RNAs de interferência e, em seguida, avaliamos a potencial regulação de E2F1 e do cluster miR-17 92.

Assim, inicialmente, para confirmar a eficiência do protocolo de transfecção e silenciamento mediado por siRNA na linhagem NTERA-2, um siRNA contra GAPDH foi transfectado e a redução dos níveis do mRNA (em relação às células transfectadas com um siRNA controle) foi avaliada 72 horas após (Figura 16). A análise por qPCR do ensaio de validação da transfecção na linhagem celular NTERA-2 revelou uma redução significativa de $91,13 \%$ dos níveis dos transcritos de GAPDH, em relação ao controle negativo, 72 horas pós-transfecção, demonstrando o sucesso do nosso protocolo.

Em seguida, procedemos com o ensaio de silenciamento de AURKA na linhagem celular NTERA-2. Os resultados representados nas figuras 17 a 19 foram obtidos por meio da técnica de PCR quantitativo $\left(2^{-\Delta \Delta C t}\right)$ nos intervalos de 72 horas e 120 horas pós-transfecção.

O ensaio de transfecção mostrou-se eficiente, com uma diminuição de cerca de $78 \%$ e $49 \%$ nos níveis de AURKA, em relação ao controle negativo, 72 horas e 120 horas pós-transfecção, respectivamente (Figura 17). Estes resultados demonstram um silenciamento robusto nos três primeiros dias o qual se estendeu até o quinto dia. 


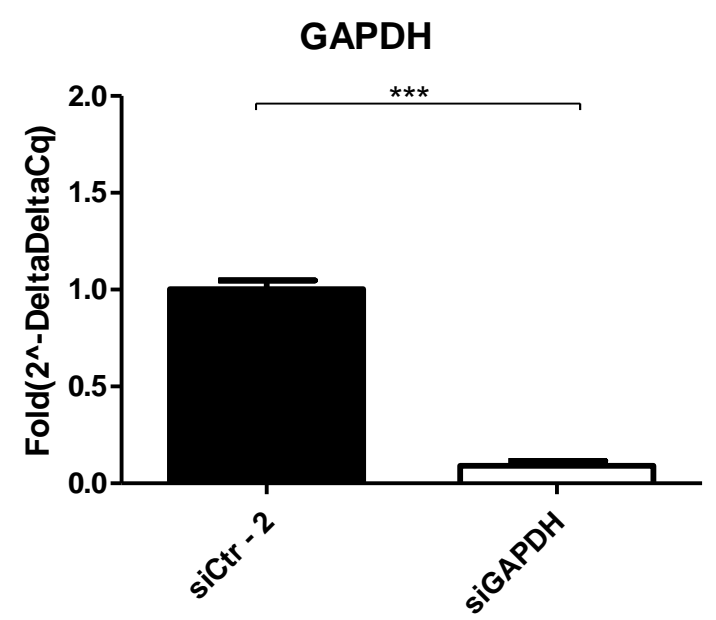

FIGURA 16. Avaliação funcional da eficiência de transfecção de células NTERA-2. Um siRNA contra GAPDH foi transfectado em células NTERA-2 e a redução dos níveis do mRNA (em relação às células transfectadas com um siRNA controle) foi avaliada 72 horas após. Grupos transfectados, em triplicata experimental. A expressão de $\beta$-Actina foi utilizada para a normalização $(\Delta \mathrm{Ct})$. ${ }^{*} 0.01<p<$ $0.05 ;{ }^{* *} 0.001<\mathrm{p}<0.01 ;{ }^{* * *} \mathrm{p}<0.001$.
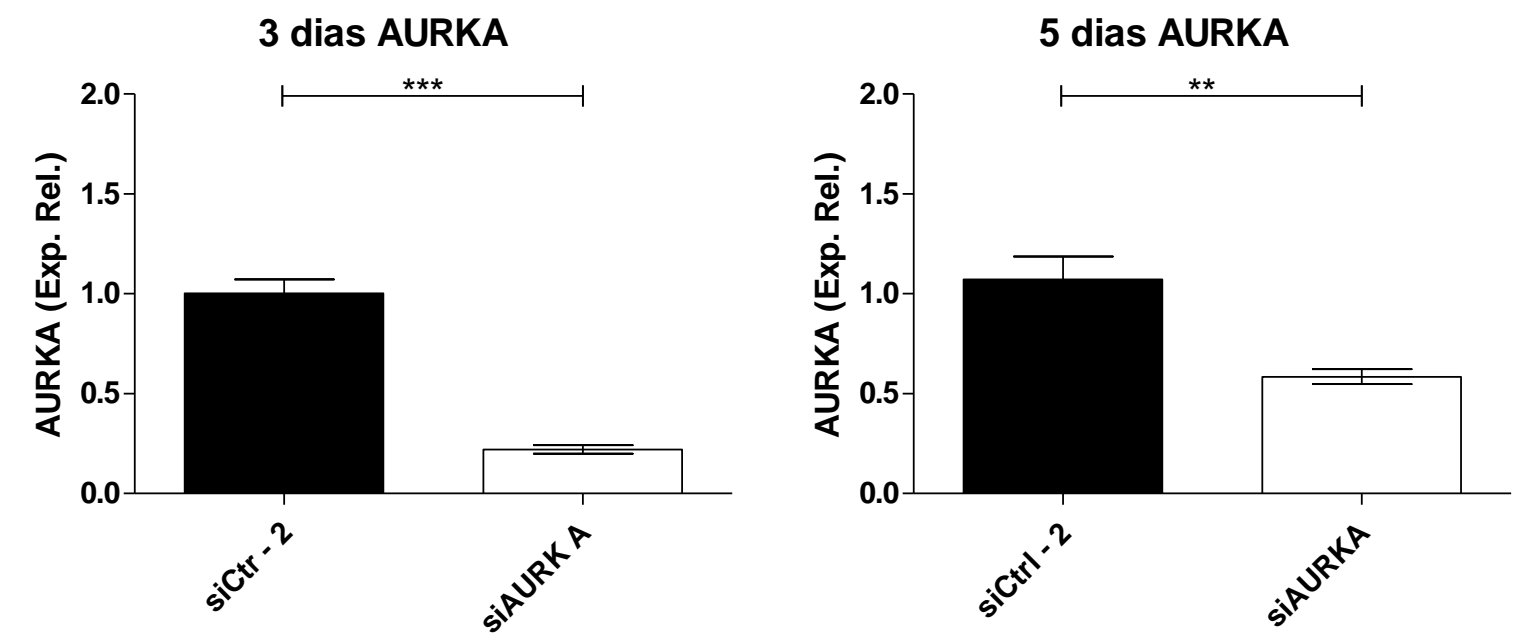

FIGURA 17. Silenciamento de AURKA por siRNA em células NTERA-2, 72 horas e 120 horas pós-transfecção. Grupos transfectados, em triplicata experimental, de siRNAs contra mRNAs de AURKA. Expressão de AURKA normalizada pela expressão de $\beta$-Actina $(\Delta \mathrm{Ct})$ em relação às células transfectadas com o siRNA controle $\left(2-{ }^{\Delta \Delta C t}\right)$. ${ }^{*} 0.01<p<0.05 ;{ }^{* *} 0.001<p<0.01 ;{ }^{* * *} p<0.001$. 
Ao avaliarmos a potencial influência do silenciamento de AURKA sobre os níveis de E2F1 nestas mesmas amostras, nossos resultados demonstraram expressiva redução nos níveis do fator de transcrição chegando, respectivamente, a $59 \%$ e $40 \%$ em relação ao controle negativo, 72 horas e 120 horas pós-transfecção (Figura 18). Tais resultados, portanto, corroboram a hipótese prévia de $\mathrm{He}$ et al. (2010).
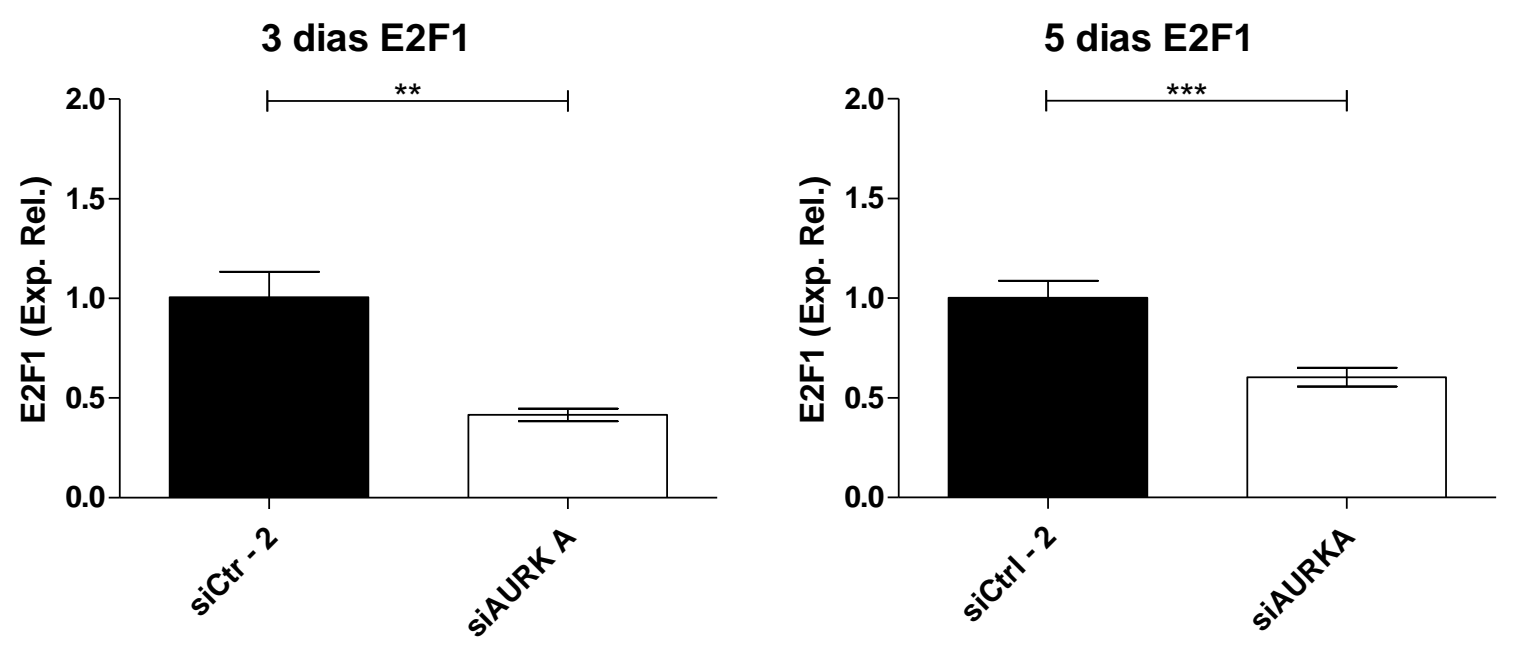

FIGURA 18. Efeito do silenciamento de AURKA sobre os níveis de E2F1. Os níveis dos transcritos de E2F1 foram avaliados 72 horas e 120 horas pós-transfecção em NTERA-2 com siRNAs contra AURKA. Grupos transfectados, em triplicata experimental. E2F1 normalizado com a expressão de $\beta$-Actina $(\Delta \mathrm{Ct}) .{ }^{*} 0.01<\mathrm{p}<0.05 ;{ }^{* *} 0.001<\mathrm{p}<0.01 ;{ }^{* * *} \mathrm{p}<0.001$.

Ainda, em linha com o eixo regulatório descrito por $\mathrm{HE}$ et al. (2010), o silenciamento dos mRNAs de AURKA, e a consequente redução de E2F1, acarretou expressiva redução nos níveis de MIR17HG, com valores aproximados de $41 \%$ em ambos os tempos avaliados (Figura 19). 

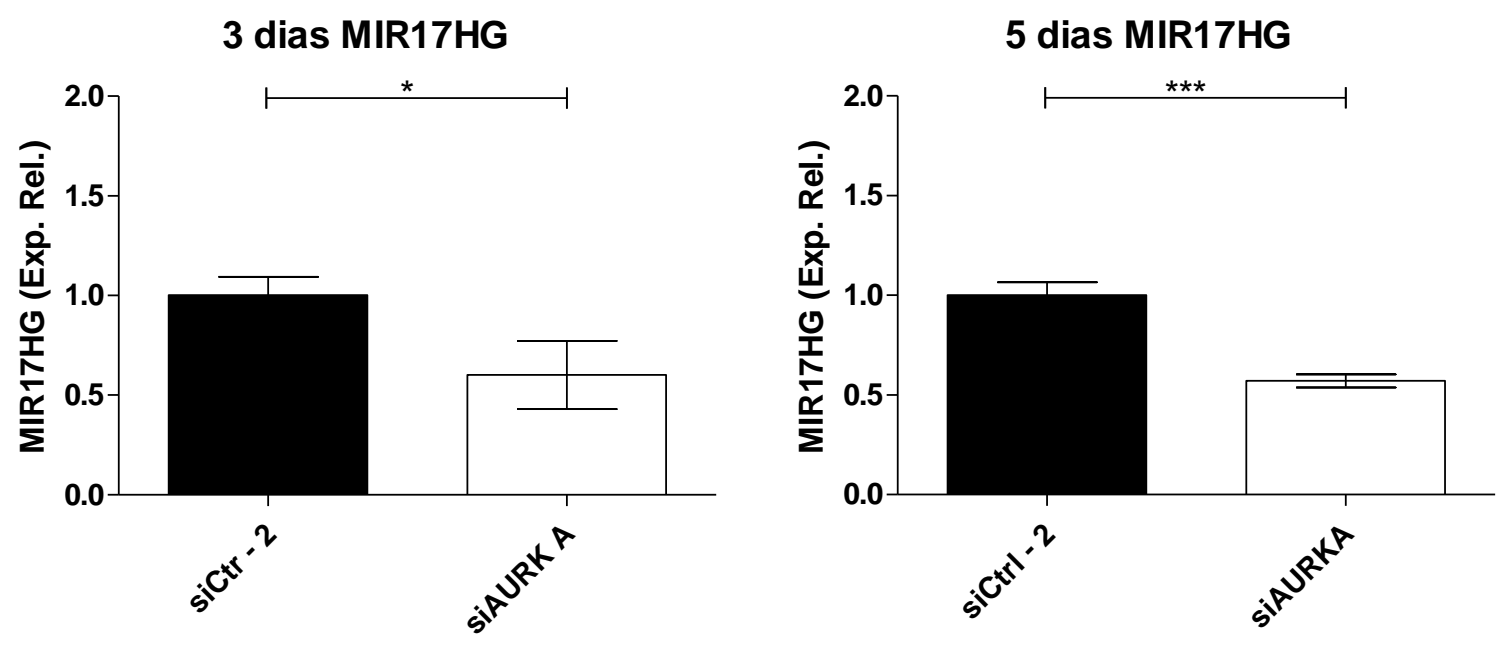

FIGURA 19. Efeito do silenciamento de AURKA sobre os níveis de MIR17HG. Os níveis dos transcritos de E2F1 foram avaliados 72 horas e 120 horas pós-transfecção em NTERA-2 com siRNAs contra AURKA. Grupos transfectados, em triplicata. MIR17HG normalizado pela expressão de $\beta$ Actina $(\Delta \mathrm{Ct}) .{ }^{*} 0.01<\mathrm{p}<0.05 ;{ }^{* *} 0.001<\mathrm{p}<0.01 ;{ }^{* * *} \mathrm{p}<0.001$.

De acordo com nossa hipótese, tendo em vista a regulação predita das variantes de DIDO por microRNAs do cluster miR-17 92, o silenciamento da AURKA (mediada pelo siRNA) e consequente redução secundária de E2F1 e terciária de MIR17HG, poderia ter como efeito potencial, um eventual acúmulo dos transcritos das variantes de DIDO. Assim, avaliamos os níveis das variantes de DIDO nestas mesmas amostras.

Interessantemente, apesar de todas as variantes de DIDO (e também GID8) terem apresentado uma leve, porém estatisticamente significativa, redução em seus níveis no terceiro dia pós-transfecção (Figuras 20 a 23), diferentemente de E2F1 e MIR17HG, as variantes DIDO2 e DIDO3 já apresentavam níveis elevados no quinto dia (Figuras 21 e 22).

Tendo em vista a redução significativa dos mRNAs de AURKA, E2F1 e MIR17HG 72 horas (3 dias) e 120 horas (5 dias) pós-silenciamento da AURKA (Figuras 17 a 19), o acúmulo de mRNA das variantes DIDO2 e DIDO3 dão indícios de que, ao quinto dia, este mecanismo poderia estar atuando. 

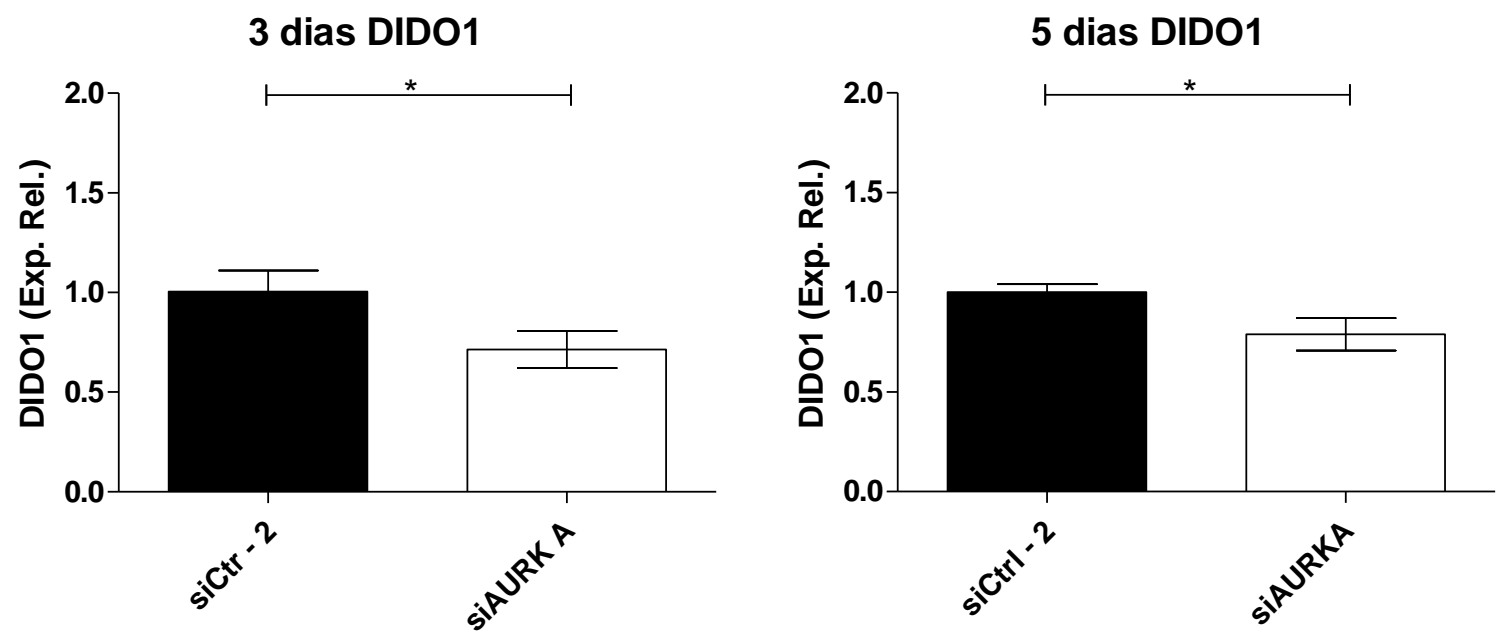

FIGURA 20. Expressão dos transcritos de DIDO1 72 horas e 120 horas pós-transfecção em NTERA-2 com siRNAs alvos de AURKA. Grupos transfectados, em triplicata experimental, de siRNAs contra mRNAs de AURKA. DIDO1 normalizado com a expressão de $\beta$-Actina $(\Delta \mathrm{Ct}) .{ }^{*} 0.01<p$ $<0.05 ;{ }^{* *} 0.001<\mathrm{p}<0.01 ;{ }^{* * *} \mathrm{p}<0.001$.

3 dias DIDO2

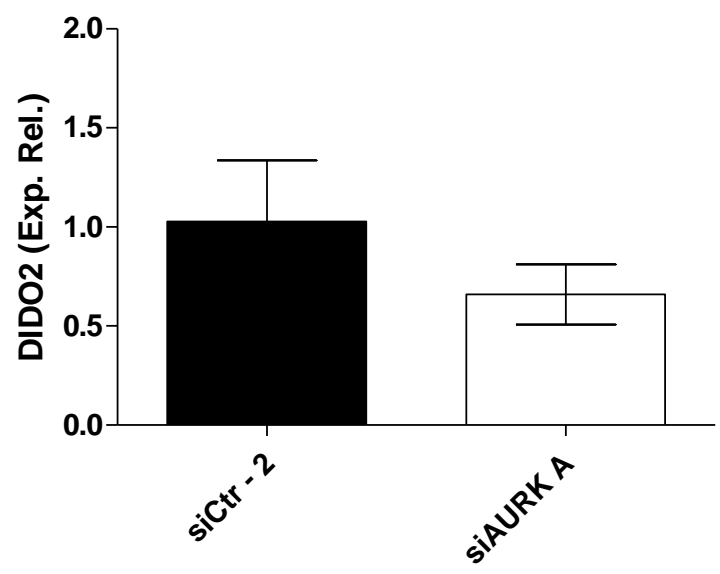

5 dias DIDO2

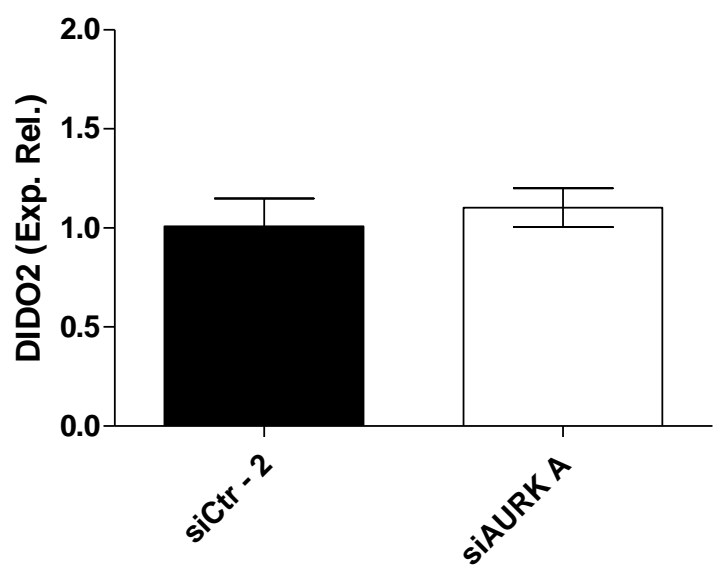

FIGURA 21. Expressão dos transcritos de DIDO2 72 horas e 120 horas pós-transfecção em NTERA-2 com siRNAs alvos de AURKA. Grupos transfectados, em triplicata experimental, de siRNAs contra mRNAs de AURKA. DIDO2 normalizado com a expressão de $\beta$-Actina $(\Delta C t) .{ }^{*} 0.01<p$ $<0.05 ;{ }^{* *} 0.001<p<0.01 ;{ }^{* * *} p<0.001$. 

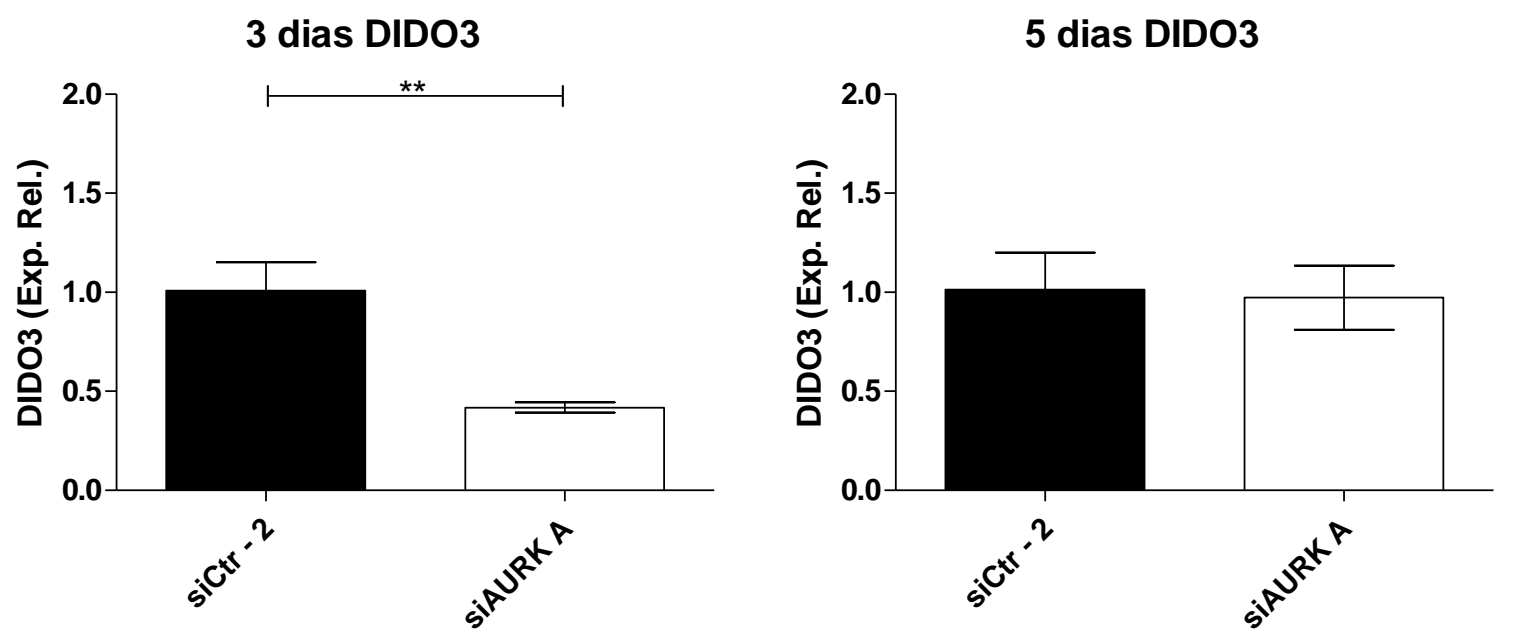

FIGURA 22. Expressão dos transcritos de DIDO3 72 horas e 120 horas pós-transfecção em NTERA-2 com siRNAs alvos de AURKA. Grupos transfectados, em triplicata experimental, de siRNAs contra mRNAs de AURKA. DIDO3 normalizado com a expressão de $\beta$-Actina $(\Delta \mathrm{Ct}) .{ }^{*} 0.01<p$ $<0.05 ;{ }^{* *} 0.001<\mathrm{p}<0.01 ;{ }^{* \star *} \mathrm{p}<0.001$.

Ainda, em paralelo com os experimentos realizados, tendo em vista que o promotor distal de DIDO compartilha sítios com GID8 e que a via de regulação entre AURKs e DIDO poderia gerar algum efeito potencial sobre GID8, resolvemos avaliar os níveis de GID8 nestas mesmas amostras após o silenciamento da AURKA (mediada pelo siRNA).

A figura 23 apresenta uma redução nos níveis de expressão de GID8 após a transfecção com siRNAs alvos dos mRNAs de AURKA de cerca de $47 \%$ e $33 \%, 72$ horas (3 dias) e 120 horas (5 dias), respectivamente. Tais resultados, todavia, apesar de se apresentarem semelhantes aos efeitos gerados do silenciamento da AURKA sobre DIDO, demonstram níveis de expressão inferiores aos de DIDO no quinto dia pós-transfecção. 

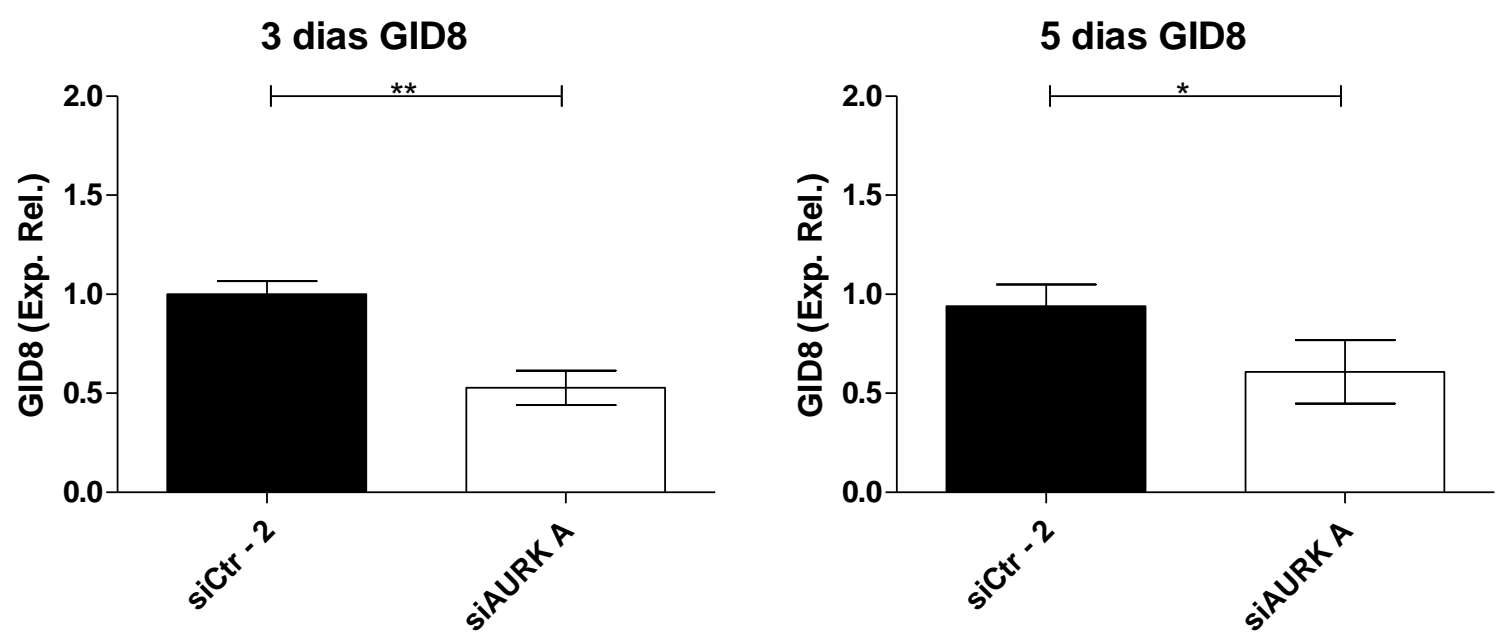

FIGURA 23. Expressão dos transcritos de GID8 72 horas e 120 horas pós-transfecção em NTERA-2 com siRNAs alvos de AURKA. Grupos transfectados, em triplicata experimental, de siRNAs contra mRNAs de AURKA. GID8 normalizado com a expressão de $\beta$-Actina $(\Delta C t)$. ${ }^{*} 0.01<p<$ $0.05 ;{ }^{* *} 0.001<p<0.01 ;{ }^{* * *} p<0.001$.

\subsection{Regulação das variantes de DIDO via cluster miR-17 92}

De forma a avaliar se alguns dos microRNAs do cluster miR-17 92 poderiam de fato regular as variantes de DIDO, moléculas miméticas de microRNAs deste cluster foram transfectadas em células NTERA-2 e os níveis dos transcritos das diferentes variantes de DIDO foram avaliadas por qPCR.

Fica evidente nas figuras 24 a 26 que no quinto dia após a transfecção, os miRs-19a -20a e -92a levam a uma redução robusta e estatisticamente significativa nos níveis dos transcritos de todas as três variantes de DIDO; o mesmo ocorrendo para o miR-18a em relação a DIDO1. Por outro lado, ao terceiro dia póstransfecção, de maneira geral nenhum dos microRNAs causa uma redução estatisticamente significativa nos níveis das variantes de DIDO, sendo que os microRNAs miR-92a e miR-18a causam um aumento discreto nos níveis de DIDO1 e DIDO2, respectivamente. 

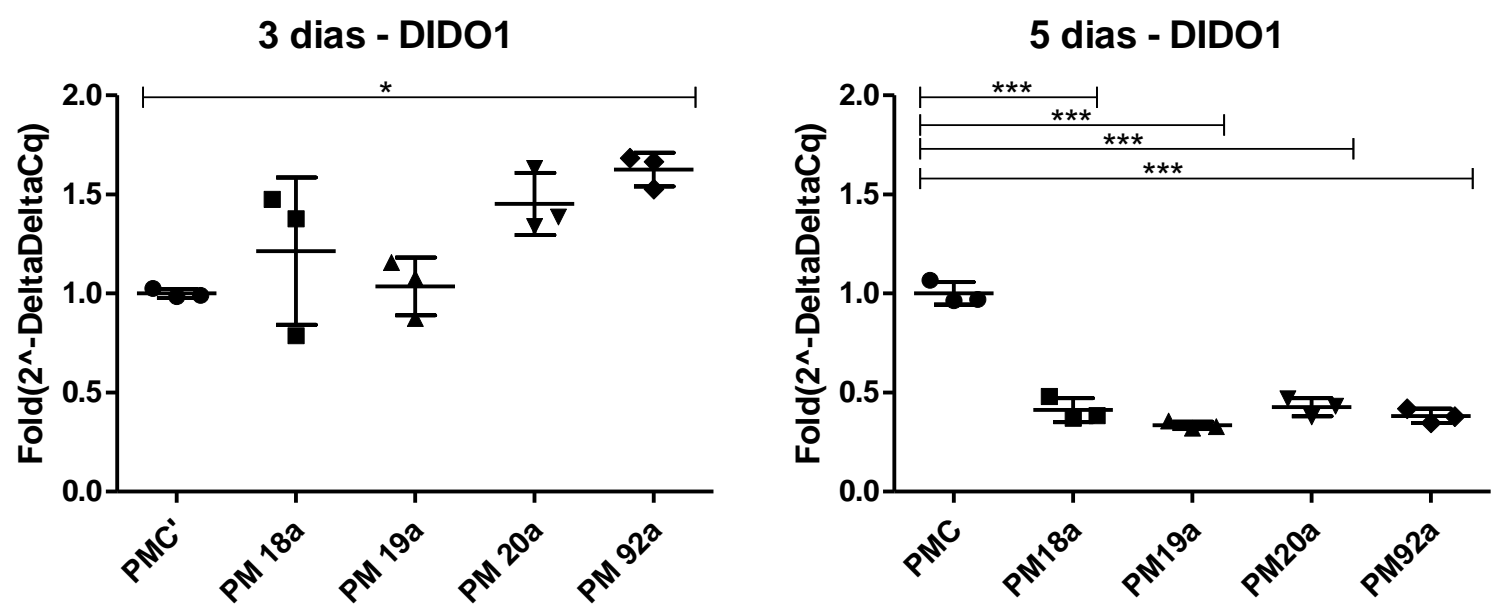

FIGURA 24. Efeito de miRNAs do cluster miR-17 92 sobre DIDO1. Expressão relativa obtida por qPCR, 72 horas e 120 horas pós-transfecção de células NTERA-2 com miRNAs miméticos do cluster miR-17 92. DIDO1 normalizado com a expressão de $\beta$-Actina $(\Delta \mathrm{Ct}) .{ }^{*} 0.01<\mathrm{p}<0.05 ;{ }^{* *} 0.001<\mathrm{p}<$ $0.01 ;{ }^{* * *} p<0.001$.

\section{3 dias - DIDO2}

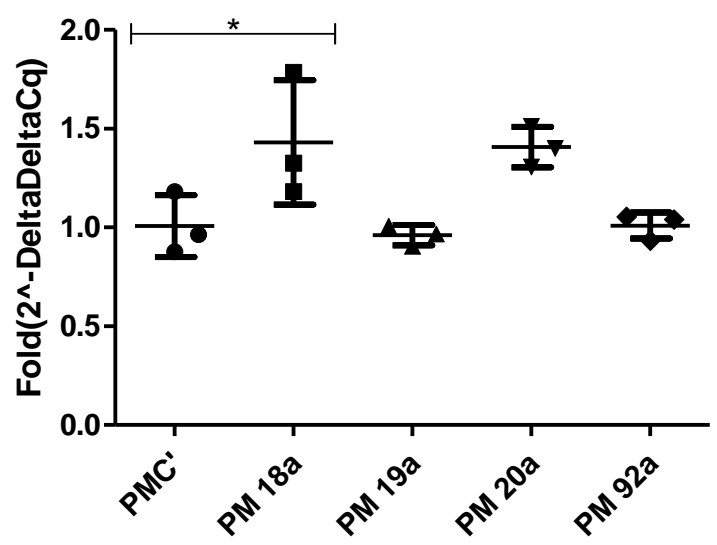

5 dias - DIDO2

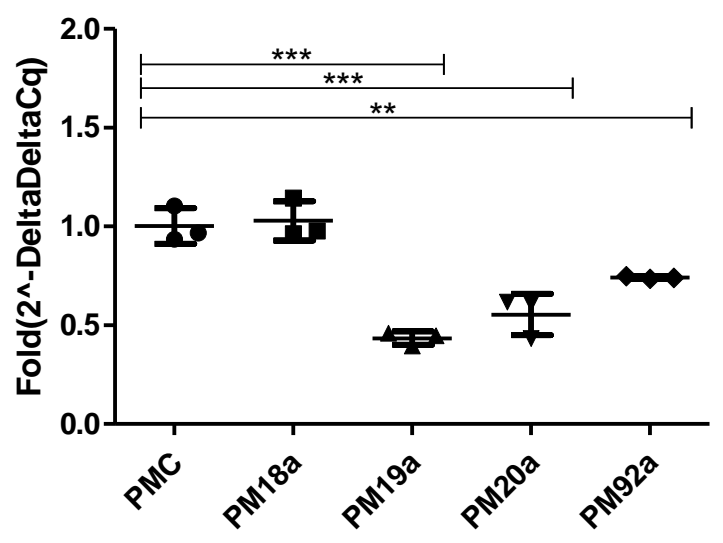

FIGURA 25. Efeito de miRNAs do cluster miR-17 92 sobre DIDO2. Expressão relativa obtida por qPCR, 72 horas e 120 horas pós-transfecção de células NTERA-2 com miRNAs miméticos do cluster miR-17 92. DIDO2 normalizado com a expressão de $\beta$-Actina $(\Delta \mathrm{Ct}) .{ }^{*} 0.01<\mathrm{p}<0.05 ;{ }^{* *} 0.001<\mathrm{p}<$ $0.01 ;{ }^{* * *} p<0.001$. 

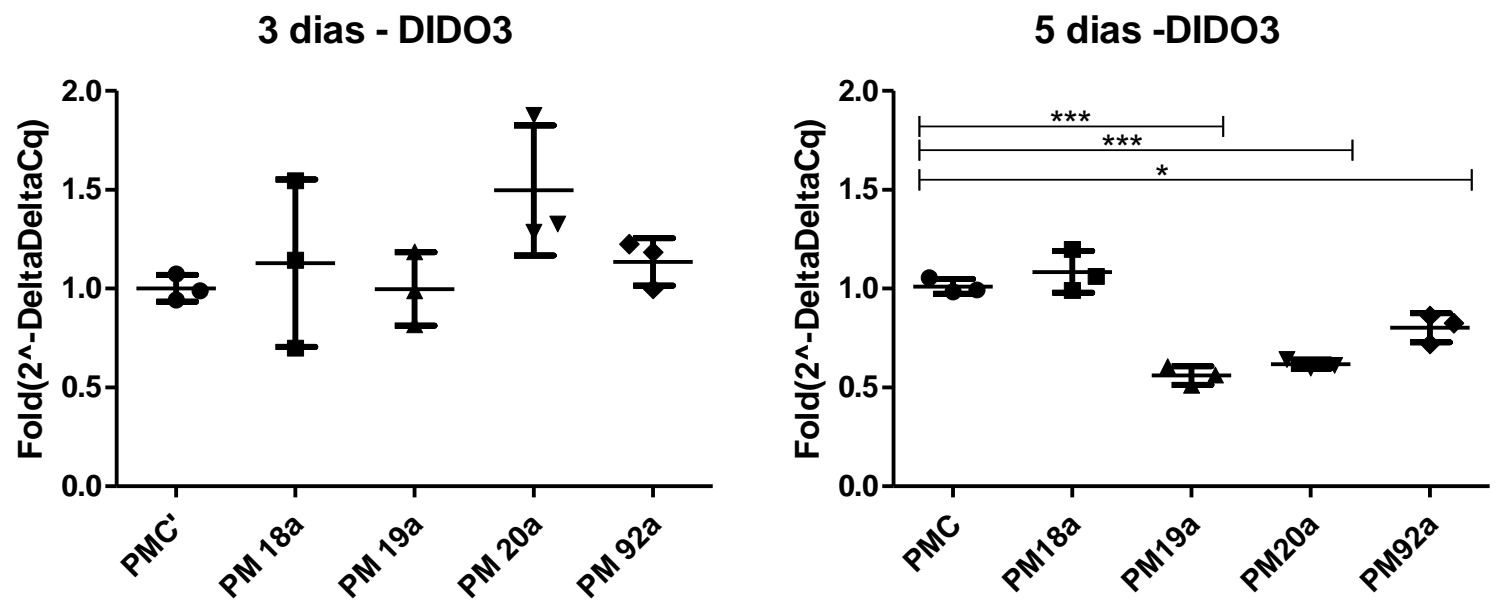

FIGURA 26. Efeito de miRNAs do cluster miR-17 92 sobre DIDO3. Expressão relativa obtida por qPCR, 72 horas e 120 horas pós-transfecção de células NTERA-2 com miRNAs miméticos do cluster miR-17 92. DIDO3 normalizado com a expressão de $\beta$-Actina $(\Delta \mathrm{Ct}) .{ }^{*} 0.01<\mathrm{p}<0.05 ;{ }^{* *} 0.001<\mathrm{p}<$ $0.01 ;{ }^{* * *} p<0.001$.

Intrigantemente, apesar de todas as três variantes terem um sítio para o miR18a, somente DIDO1 tem seus níveis reprimidos por este miRNA. Por outro lado, DIDO1 é reprimido pelos miRs miR-19a e miR-20a mesmo sem ter sítios alvos preditos em seu transcrito; o mesmo ocorre para DIDO2, que não possui sítios para o miR-92a; finalmente, DIDO3 não possui sítios alvo para o miR-19a e miR-92a.

Portanto, apesar destes resultados darem indícios da existência de algum mecanismo de regulação das variantes de DIDO, ocorrendo downstream aos microRNAs do cluster miR-17 92, não é claro se uma regulação direta poderia ser responsável por parte dos resultados observados, ou se algum mecanismo indireto seria responsável pela robusta redução nos níveis das variantes de DIDO, observada no quinto dia pós-transfecção.

Com isto em vista, buscando compreender qual mecanismo poderia ser responsável pelos resultados observados, realizamos experimentos de Western Blotting visando avaliar a potencial repressão da tradução proteica dos mRNAs das isoformas de DIDO, tanto nas amostras de células NTERA-2 submetidas ao silenciamento de AURKA, como nas submetidas à transfecção de microRNAs miméticos pertencentes ao cluster miR-17 92. 


\subsection{Análise da expressão proteica das isoformas de DIDO pós- silenciamento de AURKA}

Inicialmente, reavaliamos o silenciamento da AURKA na linhagem NTERA-2, por Western Blotting, 72 horas pós-transfecção com o siRNA contra AURKA. A avaliação mostrou uma redução de cerca de $60 \%$ nos nível proteicos de AURKA, comparado às células transfectadas com uma molécula controle de siRNA inespecífica; corroborando o silenciamento observado por qPCR com a redução nos níveis de mRNA (Figura 27).

a)

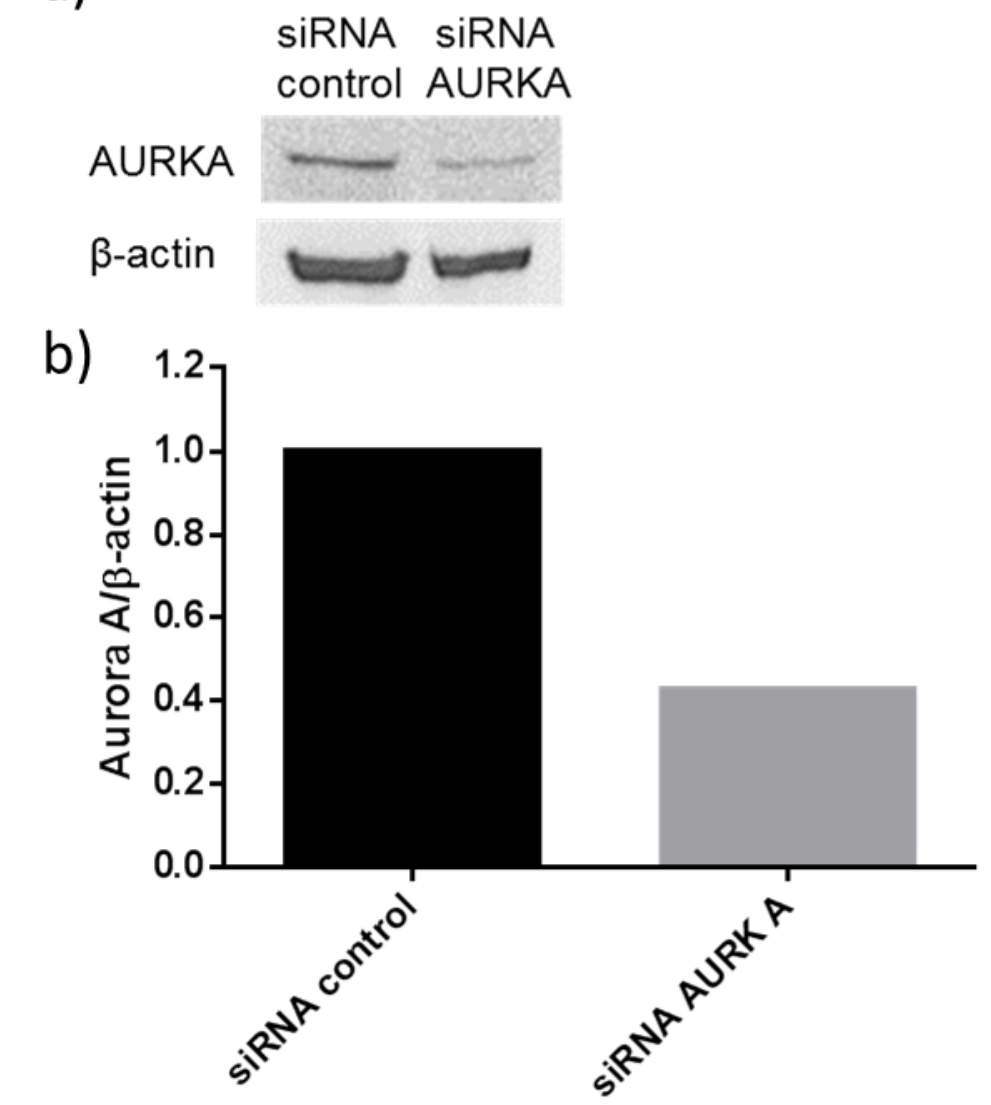

FIGURA 27. Silenciamento protéico de AURKA em células NTERA-2. Gráfico representativo da expressão proteica observada em células NTERA-2 72 horas pós-transfecção com siRNA contra AURKA ou siRNA controle. a) Imagem obtida do gel por Western Blotting utilizando anticorpo contra AURKA e contra $\beta$-Actina. b) Quantificação da imagem demonstrando a redução nos níveis da proteína AURKA, pós-silenciamento, em relação ao ás células transfectadas com o siRNA controle. Os valores foram normalizados pelos níveis endógenos de $\beta$-Actina. 
Com o objetivo de avaliar o efeito do silenciamento de AURKA sobre os níveis proteicos das variantes de DIDO, utilizamos estas mesmas amostras de proteína e avaliamos os níveis de DIDO1 e DIDO2, utilizando um anticorpo supostamente capaz de detectar as três isoformas. Como controle, visando determinar a especificidade do anticorpo contra DIDO, utilizamos um siRNA desenhado em região comum às três variantes de DIDO (ver sessão 7. Anexos Figuras 36 e 37 ).

Como demonstrado na figura 28 , os resultados obtidos 72 horas póstransfecção com o siRNA contra AURKA não revelaram alteração nos níveis de DIDO1 ou DIDO2. Estes resultados, no entanto, não são conclusivos, pois o efeito esperado do siRNA contra DIDO também não foi observado, nem para DIDO1 nem para DIDO2, levantando dúvidas sobre a capacidade do anticorpo em detectar efetivamente as isoformas de DIDO. Ainda, utilizamos as mesmas amostras proteicas utilizadas para a avaliação de AURKA, obtidas apenas 72 horas após a transfecção do siRNA, um período de tempo provavelmente insuficiente para observar os potenciais efeitos finais nos níveis de DIDO. Assim, estes experimentos foram repetidos em triplicata e com coleta das amostras no quinto dia póstransfecção do siRNA. Tais resultados, contudo, ainda estão em fase de aquisição.

A detecção da isoforma DIDO3 não foi apresentada por questões técnicas relacionadas ao seu alto peso molecular e à dificuldade de quantificá-la em relação à $\beta$-Actina (controle endógeno), simultaneamente no mesmo gel (Figura 28). Estas questões estão sendo reavaliadas de forma a permitir a quantificação de DIDO3 (e.g. uso de gel independente ou stacking gel). 


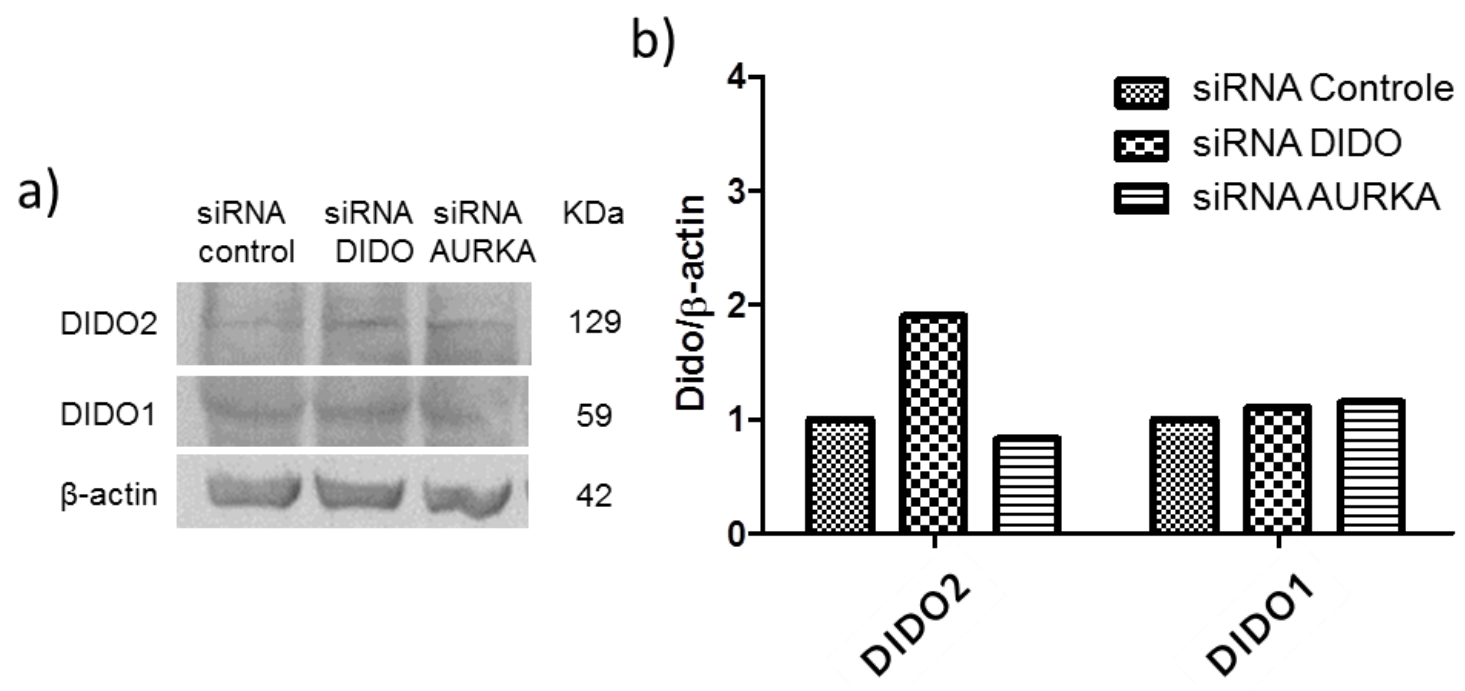

FIGURA 28. Efeito do silenciamento do mRNA AURKA e das variantes transcricionais de DIDO sobre a expressão proteica das isoformas DIDO1 e DIDO2, em NTERA-2, 72 horas póstransfecção. a) Imagem comparativa das isoformas proteicas DIDO1 e DIDO2, em relação ao endógeno $\beta$-Actina, pós-silenciamento das variantes transcricionais de DIDO e do mRNA AURKA. b) Gráfico representativo da expressão proteica diferencial entre os grupos tratados com siRNA AURKA, siRNA DIDO e grupos tratados com siRNA controle. Os valores foram normalizados com a expressão do endógeno $\beta$-Actina.

Em paralelo às avaliações nas amostras transfectadas com os siRNAs contra AURKA e contra DIDO, avaliamos a possível regulação das variantes de DIDO por microRNAs do cluster miR-17 92 (preditos como tendo sítios alvo entre as variantes de DIDO). A figura 29 apresenta a expressão proteica das isoformas DIDO1 e DIDO2, 72 horas pós-transfecção com os miRNAs miméticos do cluster miR-17 92 na linhagem celular NTERA-2. Contudo, apenas o miR-20a demonstrou aparente efeito sobre níveis proteicos da isoforma DIDO2, reduzindo-os conforme esperado.

Tendo em vista os resultados inconclusivos quanto à especificidade do anticorpo contra as isoformas proteicas de DIDO, novos ensaios em triplicata foram realizados com a finalidade de se avaliar os efeitos propostos, porém num momento mais tardio após a transfecção (5 dias). Os mesmos estão em fase de aquisição das imagens para posterior quantificação e análise. 
a)
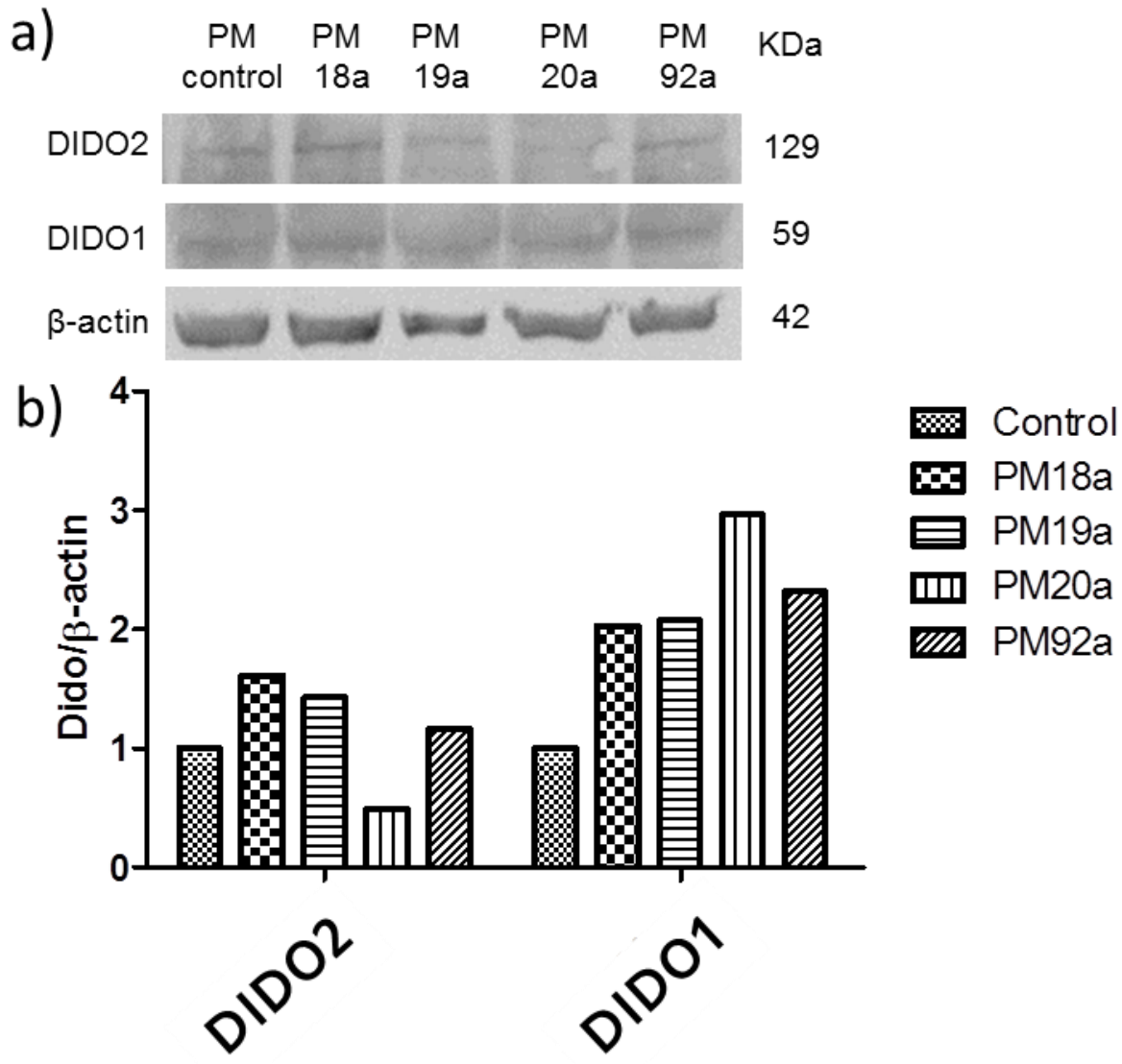

FIGURA 29. Efeito dos miRNAs do cluster miR-17 92 sobre os níveis proteicos das isoformas DID01 e DIDO2. Células NTera-2 foram transfectadas com miRNAs miméticos pertencentes ao cluster miR-17 92 e o efeito sobre os níveis proteicos das isoformas de DIDO foram determinados por Western Blotting. a) Imagem obtida do gel utilizando anticorpo contra as isoformas de DIDO e contra o controle endógeno $\beta$-Actina, 72 horas pós-transfecção com miRNAs miméticos pertencentes ao cluster miR-17 92. b) Gráfico ilustrando a quantificação relativa das isoformas DIDO1 e DIDO2 nas amostras tratadas com diferentes miRNAs do cluster miR-17 92, em relação aos grupos tratados com miRNAs controle. Os valores foram normalizados pelos níveis de expressão da $\beta$-Actina.

\subsection{Silenciamento das isoformas de DIDO por siRNAs específicos}

Ao avaliarmos a especificidade dos siRNAs, adquiridos da empresa Life Technologies, desenhados por meio de uma ferramenta oriunda do próprio fornecedor, observamos que os siRNAs não demonstraram os resultados esperados em relação aos seus alvos (veja a sessão 7 de Anexos). As análises realizadas revelaram um erro da ferramenta de desenho da Life Technologies. Assim, novos siRNAs foram fornecidos sem custos pela empresa, desta vez contra regiões 3`UTR 
específicas de cada uma das variantes de DIDO. A figura 30 indica o alinhamento com o genoma de cada siRNA avaliado e das variantes transcricionais de DIDO.

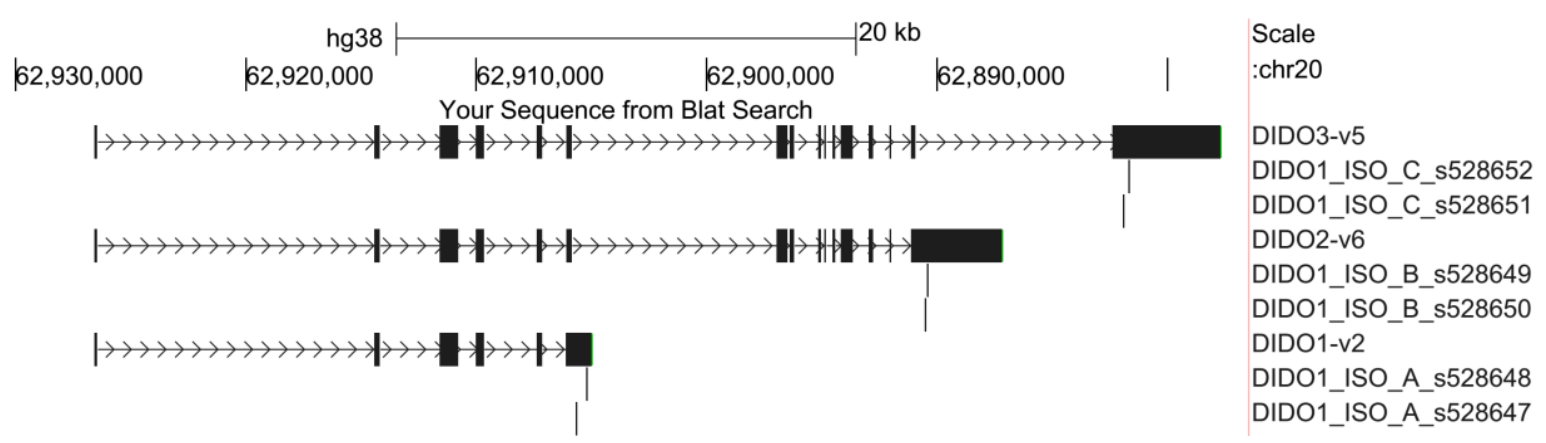

FIGURA 30. Alinhamento dos siRNAs específicos contra regiões $3^{\prime}$-UTR específicas das variantes de DIDO. Para claridade, apenas as variantes transcritas a partir do promotor proximal de DIDO estão apresentadas. Imagem adquirida por meio da plataforma digital BLAT (UCSC Genome Browser).

Garantida a especificidade no desenho dos siRNAs, com o objetivo de verificar potenciais efeitos inespecíficos dos siRNAs, a linhagem celular NTERA-2 foi transfectada com todos os diferentes siRNAs contra as três variantes de DIDO, além do siRNA controle negativo, e do siRNA contra GAPDH (controle positivo). Ensaios de qPCR foram então realizados 72 horas e 120 horas pós-transfecção.

A avaliação dos níveis de GAPDH revelou, como esperado, um silenciamento eficiente e robusto, indicando o sucesso da transfecção. No entanto, esta análise acabou por demonstrar um efeito inesperado com o siDIDO3-52, que induziu fortemente a expressão de GAPDH no quinto dia após a transfecção, fato que não ocorreu com os outros siRNAs (Figura 31). Estes resultados nos fizeram avaliar, novamente, a potencial inespecificidade dos siRNAs. 

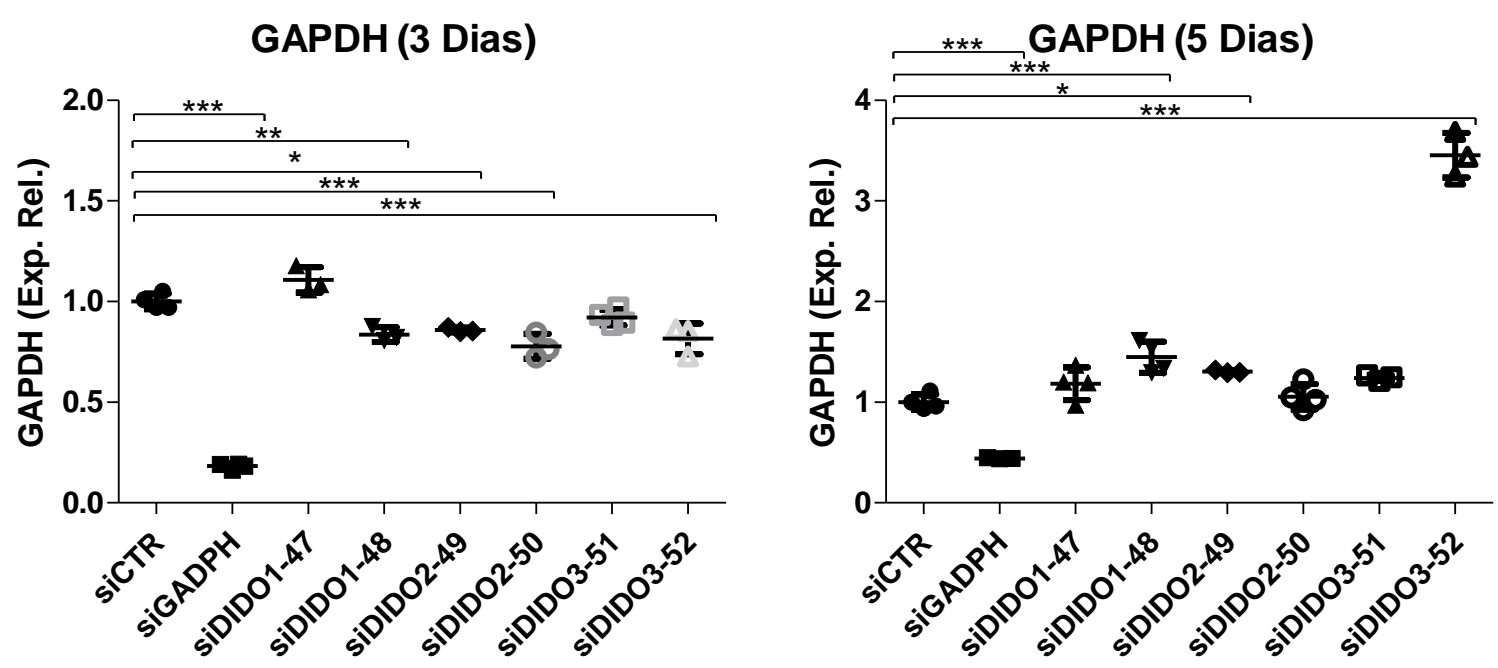

FIGURA 31. Avaliação de efeitos inespecíficos dos siRNAs utilizados, sobre a expressão do gene endógeno GAPDH. A linhagem NTERA-2 foi transfectada com os diferentes siRNAs, tendo os níveis do transcrito de GAPDH avaliado após 3 e 5 dias. Os grupos foram transfectados em quadruplicata experimental. Os níveis de GAPDH foram quantificados e normalizado pela expressão de $\beta$-Actina $(\Delta \mathrm{Ct})$. A média dos valores de $\Delta \mathrm{Ct}$ obtidos para o grupo transfectado com o siRNA controle (sem alvo em humano) foi utilizado como valor de referência para cálculo de expressão relativa $(2-\Delta \Delta \mathrm{Ct})$. A figura mostra a eficiência da transfecção e do silenciamento do GAPDH pelo siRNA contra GAPDH, além de uma aparente indução inesperada nos níveis de GAPDH, pelo siDIDO3-52. * $0.01<p<0.05 ;{ }^{* *} 0.001<p<0.01 ;{ }^{* * *} p<0.001$.

Para identificar potenciais alvos off-target, utilizamos a ferramenta siRNACheck (http://projects.insilico.us/SpliceCenter/siRNACheck), permitindo até duas bases não-complementares (mismatches) no alinhamento do siRNA com potenciais transcritos alvo. Dentre todos, somente o siDIDO3-52 teve um potencial alvo adicional inespecífico identificado, o gene WIPF2. Portanto, o resultado observado para GAPDH pode ser em decorrência desse alvo inespecífico em especial (Figura 31). Desta forma, escolhemos o siDIDO3-51 para estudos adicionais.

As demais avaliações, representadas nas figuras 32 a 34, mostram o efeito dos siRNAs específicos contra as diferentes variantes de DIDO, sobre os níveis dos transcritos de cada uma das variantes (obtidos por PCR quantitativo).

A figura 32 apresenta a expressão relativa da variante transcricional DIDO1, 72 horas ( 3 dias) e 120 horas (5 dias) pós-transfecção com os siRNAs contras as variantes de DIDO. As análises do ensaio no terceiro dia pós-transfecção revelaram 
uma redução significativa nos níveis dos transcritos de DIDO1, em relação ao controle negativo, enquanto que os siRNAs contra DIDO2 não tiveram efeito significativo. Entretanto, nestas mesmas condições experimentais, siRNAs específicos para DIDO3 também acarretaram uma redução drástica nos níveis da variante transcricional DIDO1. As análises no quinto dia pós-transfecção revelaram, de maneira geral, uma normalização dos níveis dos transcritos de DIDO1, em relação ao controle negativo, no entanto, o siRNA contra DIDO2 (siDIDO2-50) levou a um leve aumento nos níveis de DIDO1.

DID01 (3 Dias)

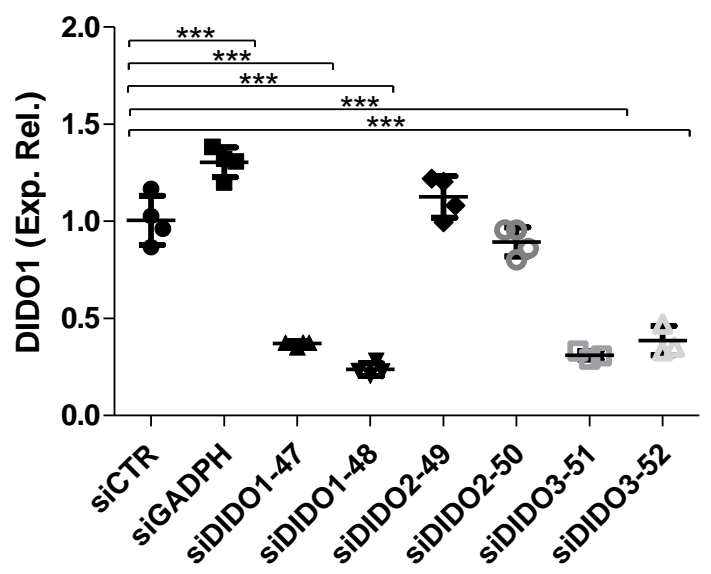

DID01 (5 Dias)

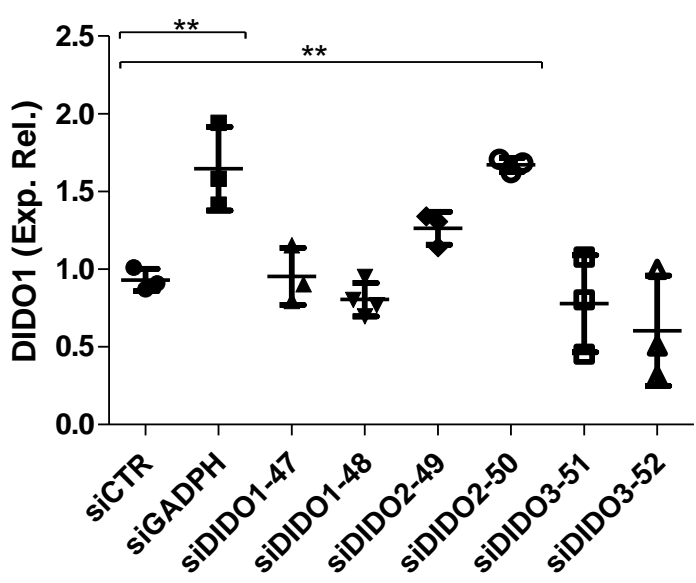

FIGURA 32. Expressão da variante transcricional DIDO1 72 horas e 120 horas pós-transfecção, em NTERA-2, com siRNAs alvo específicos. Grupos transfectados, em triplicata experimental, de controles negativo e positivo de silenciamento, assim como de siRNAs exclusivos de cada variante transcricional de DIDO. DIDO1 normalizado com a expressão de $\beta$-Actina $(\Delta C \mathrm{t})$. ${ }^{*} 0.01<p<0.05$; ** $0.001<\mathrm{p}<0.01 ;{ }^{* * *} \mathrm{p}<0.001$.

A figura 33 apresenta gráficos de expressão relativa da variante transcricional DIDO2. As análises do ensaio com 3 dias pós-transfecção revelaram um silenciamento significativo de DIDO2, com redução da expressão em relação ao controle negativo. Entretanto, mais uma vez, siRNAs específicos para DIDO3 também demonstraram-se capazes de reduzir os níveis da variante transcricional DIDO2. Estes resultados indicam que a transcrição ou estabilidade dos mRNAs de DIDO1 e DIDO2 possam depender de DIDO3. 
Ainda, um dos siRNAs para DIDO1 (siDIDO1-48) apresentou efeito aparentemente inespecífico, reduzindo os níveis da variante transcricional DIDO2. Os níveis de DIDO2 foram normalizados no quinto dia pós-transfecção, em relação ao controle negativo, no entanto, ambos siRNAs contra DIDO3 causaram uma grande variação nos níveis de DIDO2.
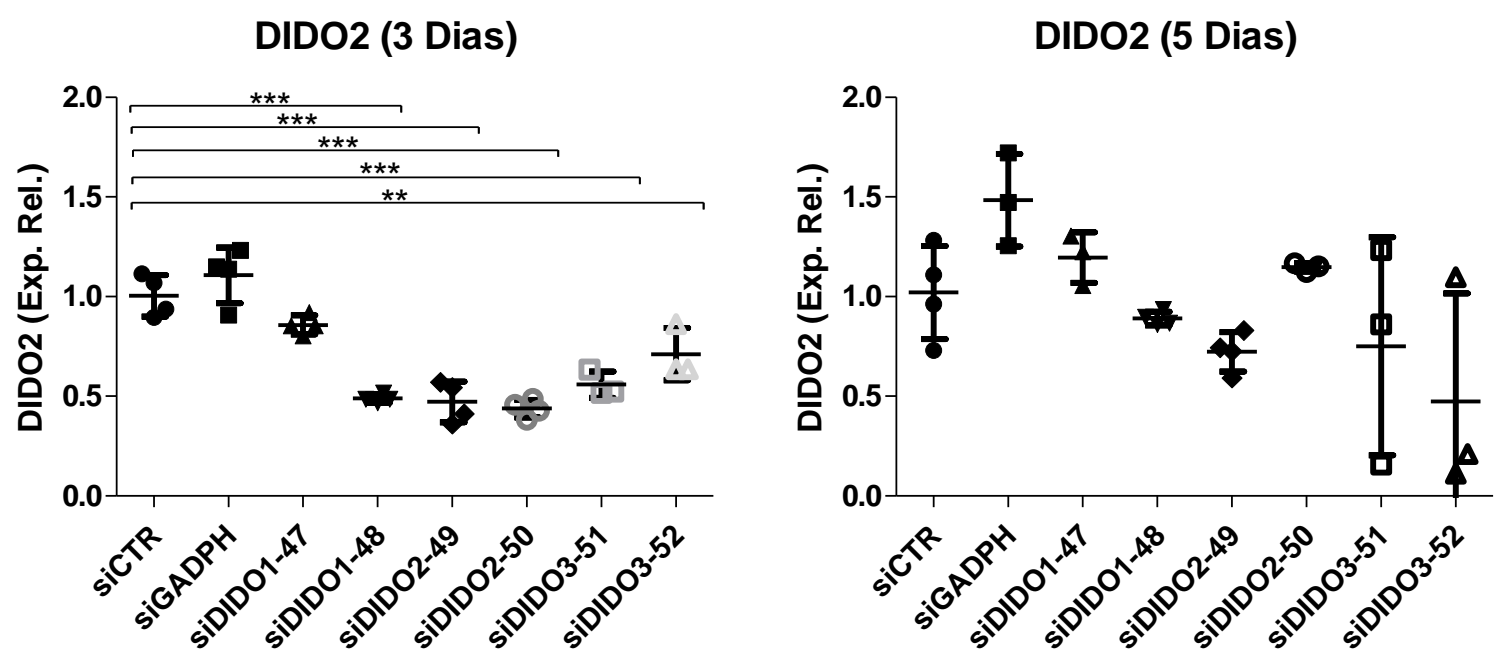

FIGURA 33. Expressão da variante transcricional DIDO2 72 horas e 120 horas pós-transfecção, em NTERA-2, com siRNAs alvo específicos. Grupos transfectados, em triplicata experimental, de controles negativo e positivo de silenciamento, assim como de siRNAs exclusivos de cada variante transcricional de DIDO. DIDO2 normalizado com a expressão de $\beta$-Actina $(\Delta C \mathrm{Ct})$. ${ }^{*} 0.01<\mathrm{p}<0.05$; ** $0.001<\mathrm{p}<0.01 ;{ }^{\star \star *} \mathrm{p}<0.001$.

A figura 34 apresenta gráficos de expressão relativa da variante transcricional DIDO3. As análises no terceiro dia pós-transfecção revelaram um silenciamento significativo no nível dos transcritos de DIDO3, em relação ao controle negativo.

Assim como observado para DIDO2, o siRNA para DIDO1 (siDIDO1-48) apresentou efeito aparentemente inespecífico reduzindo os níveis de DIDO3. Cinco dias pós-transfecção, os níveis de DIDO3 apresentavam-se ainda baixos com o siDIDO3-52, mas normalizados com o outro siRNA.

Ainda, tal qual para os níveis de DIDO1, os níveis de DIDO3 estavam levemente aumentados no quinto dia, em células transfectadas com o siRNA siDIDO2-50 contra DIDO2. 

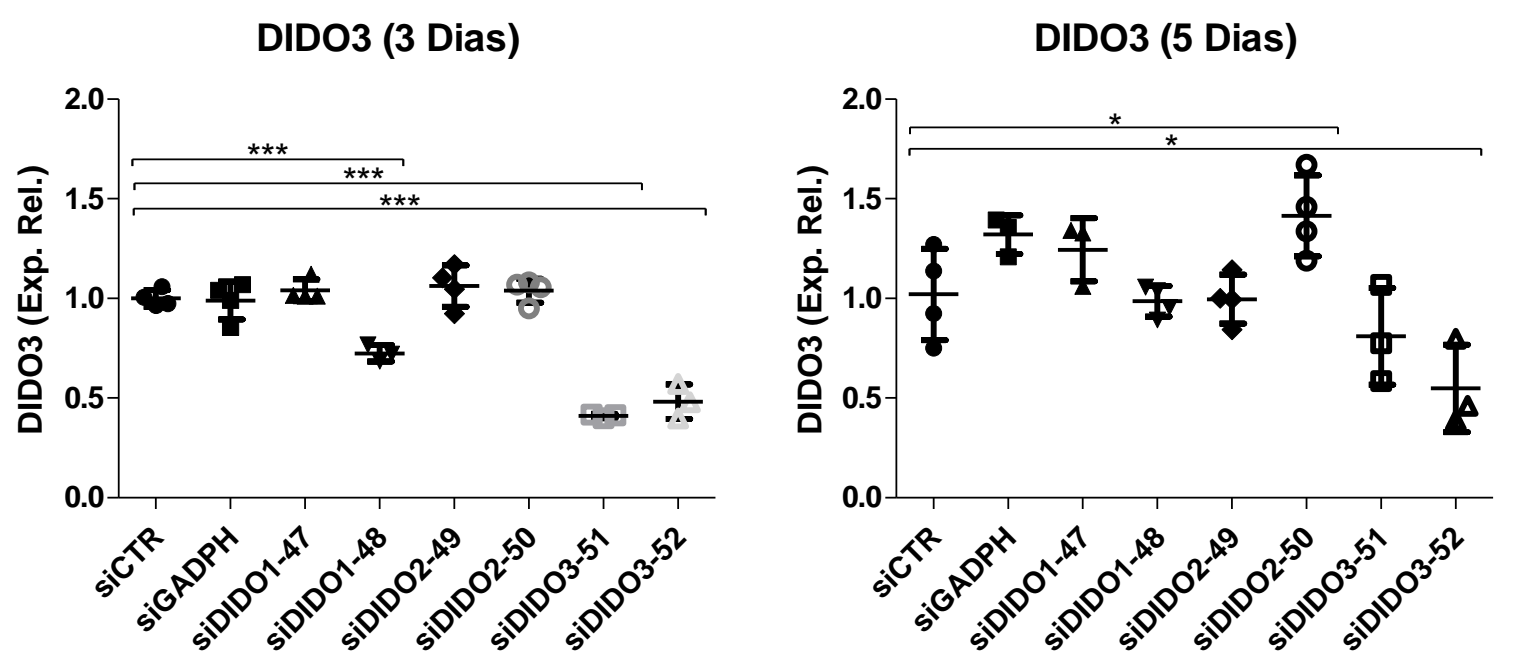

FIGURA 34. Expressão da variante transcricional DIDO3 72 horas e 120 horas pós-transfecção, em NTERA-2, com siRNAs alvo específicos. Grupos transfectados, em triplicata experimental, de controles negativo e positivo de silenciamento, assim como de siRNAs exclusivos de cada variante transcricional de DIDO. DIDO3 normalizado com a expressão de $\beta$-Actina $(\Delta \mathrm{Ct}) .{ }^{*} 0.01<\mathrm{p}<0.05$; * $0.001<\mathrm{p}<0.01 ;{ }^{* * *} \mathrm{p}<0.001$. 
5.DISCUSSÃO 
Neste trabalho nós revelamos que dentre as LLCs apresentando alterações cromossômicas, um subgrupo caracterizado pela expressão reduzida das variantes de DIDO e expressão aumentada das AURKs (em comparação à amostras de LLC, ou à controles normais, sem alterações citogenéticas) está associado a ganhos cromossomais e a contagens elevadas de leucócitos. Ainda, levantamos a hipótese e mostramos indícios de que os níveis opostos das AURKs e das variantes de DIDO podem ser resultado de um mecanismo regulatório que envolveria a indução e ativação do fator de transcrição E2F1 por AURKA, levando à transcrição do cluster do miR-17 92 e, finalmente, à consequente redução dos níveis das variantes de DIDO. Potencialmente, esta redução se daria por mecanismos pós-transcricionais envolvendo a ligação de microRNAs a sítios alvo presentes nos transcritos com sua consequente desestabilização ou; alternativamente, pela repressão transcricional indireta de todos os transcritos do lócus DIDO, por um mecanismo que envolveria a inibição intermediária de DIDO3.

A LLC caracteriza-se pelo acúmulo de pequenas células $B$ maduras no sangue, medula óssea e órgãos linfoides secundários, sendo classificada usualmente por critérios prognósticos baseados apenas em parâmetros clínicos e exames laboratoriais de rotina; incluindo a classificação RAl ou Binet, ambas subdivididas em três estágios ( 0 , I e II; ou A, B ou C, respectivamente) em ordem crescente de pior prognóstico. Estes pacientes só tem indicação para o início de tratamento quimioterápico a partir do estagio III ou C, ou com a doença ativa ou sintomática; geralmente sendo tratados com uma quimioimunoterapia combinada de fludarabina (analogo de purinas que interfere na síntese do DNA), ciclofosfamida (agente alquilante que provoca danos ao DNA e apoptose via ativação de P53), e rituximab (anticorpos monoclonais contra CD20), sendo que este tratamento pode ser repetido em pacientes com recaída, se o intervalo sem tratamento for superior a dois ou três anos (HALLEK, 2015).

Apesar da classificação RAl e Binet serem amplamente utilizadas, tendo em vista sua simplicidade, outros fatores prognósticos vem sendo cada vez mais utilizados, incluindo a determinação da porcentagem de linfócitos $B$ positivos para os marcadores de membrana ZAP-70 ou CD38 por citometria de fluxo, com maiores percentagens associadas a um pior prognóstico; ou a determinação do estado 
mutacional dos genes cadeia pesada da imunoglobulina (IGHV) por sequenciamento, com genes não-mutados associados a um pior prognóstico (CRESPO et al., 2003; DAMLE et al., 1999; HAMBLIN et al., 1999).

Do ponto de vista citogenético, com base em métodos clássicos, até pouco tempo a LLC era caracterizada principalmente por ganhos e deleções (del), ao invez de translocações, em contraste ao observado em outras doenças malignas hematológicas. Neste contexto, as anormalidades cromossômicas mais comumente identificadas e utilizadas para estratificação de risco incluiam a trissomia do cromossomo 12 seguido da deleção dos braços longos (q) dos cromossomos 13 e 11, e do braço curto (p) do cromossomo 17; com pacientes com del(13q) com bom prognóstico e pacientes com del(17p) com prognóstico ruim, com rápida progressão da doença, resistência ao tratamento e sobrevida diminuida (DOHNER et al., 2000; JULIUSSON et al., 1990).

Deleções do braço curto do cromossomo 17 (del (17p)) quase sempre incluem banda 17p13, onde o gene supressor tumoral TP53 está localizado, limitando o efeito de agentes alquilantes que induzem a apoptose por esta via. Assim, pacientes com del (17p) ou mutação inativadora no gene TP53 podem ter a indicação para tratamento com Ibrutinib ou uma combinação de Idelalisib e Rituximab (inibidores de BTK e PI3K, componentes da via de sinalização de BCR) e; caso sejam pacientes recidivos, refratários à quimioterapias repetidas, um transplante alogênico de células-tronco hematopoéticas pode ser considerado (HALLEK, 2015).

A limitação em se identificar outras aberrações cromossomais, além das mencionadas acima, se deveu principalmente à dificuldade em se obter metáfases análisáveis com o uso dos mitógenos comumente utilizados pelos métodos de citogenética clássica e, também, devido às limitações dos estudos utilizando sondas de FISH (fluorescence in situ hybridization), que apesar de permitirem a identificação de alterações específicas em núcleos interfásicos não dividindo, não permitem a identificação de qualquer outra alteração que não as detectadas pelas sondas utilizadas (ABRUZZO, 2016).

Somente recentemente, uma variedade de nóvos métodos de estimulação proliferativa específicas para as células da LLC (por ex., oligos-CPG agonistas de 
TLR9), permitiram a obtenção concistente de metáfases, viabilizando uma avaliação citogenética mais ampla e rotineira (MUTHUSAMY et al., 2011). Como resultado destas inovações, novos estudos deixaram claro que a presença de translocações (balanceadas ou não) não são incomuns na LLC e que; a ocorrência de um cariótipo complexo (com 3 ou mais anomalias citogenéticas clonais) ou de translocações solitárias são considerados fatores independentes de mal prognóstico, impactando o tempo livre de tratamentos, com base numa análise de regressão multivariada incluindo fatores como fase Binet, expressão de CD38 e deleção do 17p (MAYR et al., 2006). Digno de nota, os estudos em pacientes com LLC utilizam o Tempo Livre de Tratamentos como parâmetro de avaliação do prognóstico, uma vez que, devido à caracteristica indolente e evolução clínica lenta da LLC, os dados de Sobrevida Global (tempo até a morte) dependem de tempos de observação muito longos.

Estes estudos iniciais forneceram fortes indícios de que a instabilidade cromossômica nas células B da LLC como um todo, e não apenas alterações genéticas pontuais, teriam um papel importante na fisiopatologia da LLC, não apenas na progressão para sub-tipos mais agressivos da doença, mas em sua própria gênese. De fato, estas suspeitas foram recém corroboradas por dois grandes estudos, utilizando diversas técnicas de citogenetica e citogenômica, que confirmaram de forma clara que a complexidade cariotípica é um forte critério independente preditor de mal prognóstico, tanto em pacientes iniciais recebendo regimes de tratamento mais leves, como de pacientes refratários em recaída recebendo terapias de segunda linha baseadas em inibidores da via BCR (HERLING, C. D. et al., 2016; THOMPSON et al., 2015).

Nossos resultados vão ao encontro desses recentes achados, uma vez que nós identificamos uma clara associação entre ganhos cromossomais e contagens de glóbulos brancos aumentadas. Tendo em vista que a contagem de glóbulos brancos é um marcador de prognóstico independente em análises multivariadas que incluem parâmetros puramente clínicos ou clínico-biológico de LLC (DEL GIUDICE et al., 2011), nosso resultados são condizentes com mecanismos de instabilidade cromossômica levando a aneuploidias e à aquisição de vantagens adaptativas durante o processo evolutivo neoplásico, como frequentemente descrito para outras neoplasias (BAKHOUM; COMPTON, 2012). Mais especificamente, nosso estudo 
revela que a expressão reduzida das variantes de DIDO e a expressão aumentada das AURKs caracterizam um subgrupo de pacientes com LLC contendo aberrações citogenéticas que apresentam significativamente mais ganhos cromossomais, quando comparados às amostras de LLC com expressão destes genes equiparável à observada em controles normais ou à observada em amostras de LLC sem alterações citogenéticas.

A correta segregação cromossômica é regulada por um mecanismo conhecido como ponto de checagem do fuso mitótico (SAC, Spindle-Assembly Checkpoint), que monitora a fixação dos cinetócoros das cromátides-irmãs aos microtúbulos oriundos de polos opostos do fuso, retardando o início da anáfase até que todos os cromossomos estejam adequadamente ligados (RICKE; VAN DEURSEN, 2011). A hiperexpressão ou o ganho de função das Aurora-quinases está associado à instabilidade cromossômica, interferindo no SAC, levando a centrossomos supranumerários e fusos mitóticos defeituosos, resultando em aneuploidias e resistência à apoptose (HEGYI; MEHES, 2012; MEHRA et al., 2013; NIKONOVA et al., 2013). Similarmente, DIDO3 também tem um papel na manutenção da estabilidade cromossômica, no entanto, neste caso é a inativação ou a hipoexpressão desta proteína que promove a amplificação dos centrossomos e a atenuação dos pontos de checagem do fuso mitótico, acarretando instabilidade cromossômica e aneuploidias (GUERRERO; GAMERO; et al., 2010; GUERRERO; MARTINEZ; et al., 2010; TRACHANA et al., 2007). A amplificação centrossomal pode causar falhas na ligação dos cinetócoros aos microtúbulos levando a erros na separação dos cromossomos. A exemplo, a ligação de microtúbulos de apenas um dos polos a um ou a ambos os cinetócoro das cromátides irmãs (denominadas ligações monotélicas ou sintélicas, respectivamente), pode causar a segregação de ambas as cromátides a apenas uma das células filhas durante a anáfase, resultando em ganhos cromossomais (CIMINI, 2008).

Tendo em vista o exposto acima, nossos resultados indicariam que os ganhos cromossomais associados ao subgrupo identificado por nós (com expressão reduzida das variantes de DIDO e a expressão aumentada das AURKs) poderiam ter origem na amplificação centrossomal. Importantemente, a amplificação dos centrossomos pode levar a erros na segregação cromossomal e à aneuploidia, 
sendo frequentemente detectada em diversos subtipos de doenças malignas de células B (CHAN, 2011), incluindo a leucemia linfoide crônica (LLC), onde se correlaciona com a atividade proliferativa dos linfócitos e com maior agressividade da doença (HENSEL et al., 2007). Apesar dessa associação, a presença de aberrações cromossômicas específicas, preditoras de mal-prognóstico, não se correlaciona com aberrações centrossomais na LLC (OTTAGGIO et al., 2008). Isto poderia indicar que, de fato, a associação entre amplificação centrossomal, proliferação dos linfócitos e agressividade da doença poderia advir da instabilidade cromossômica e da aquisição de um cariótipo complexo (e uma vantagem evolutiva), e não de alterações específicas.

Surpreendentemente, apenas um único estudo anterior ao nosso relatou que a Aurora-quinase A estaria superexpressa em células de pacientes com LLC (em comparação com linfócitos de indivíduos saudáveis), apresentando uma localização principalmente nuclear e estando associada à presença da histona $\mathrm{H} 3$ acetilada (sugerindo uma superativação da mesma). Ainda, neste mesmo estudo, anormalidades cromossômicas foram detectadas em 28 (67\%) dos 42 pacientes com níveis elevados de Aurora $\mathrm{A}$, incluindo trissomia do cromossomo 12 e deleção do gene ATM (del11q23), alterações sabidamente associadas com um curso clínico acelerado em doentes com LLC (INAMDAR et al., 2008). Apesar de não ter identificado nenhuma associação específica entre a expressão de AURKA e a presença de anormalidades cromossomais, estes resultados dão suporte ao mecanismo proposto por nós, onde a superexpressão da Aurora-quinase A poderia estar envolvida na gênese de anormalidades cromossômicas na LLC.

Em adição a esses achados, nosso estudo tentou avançar no sentido de identificar potenciais mecanismos regulatórios que estariam envolvidos na relação inversa entre os níveis de expressão das AURKs e das variantes de DIDO, no subgrupo com ganhos cromossomais e número de glóbulos brancos aumentados. Com isto em vista, voltamos nossa atenção para a literatura científica. Interessantemente, a AURKA é capaz de induzir a transcrição do cluster miR-17 92 (MIR17HG), indiretamente, por meio do aumento dos níveis e consequente atividade do fator de transcrição E2F1 (HE et al., 2010), que se liga ao promotor do cluster ativando sua transcrição (SYLVESTRE et al., 2007). Ainda, a família dos miRNAs do 
cluster miR-17 92 tem expressão elevada nas LLCs de pior prognóstico, nãomutadas ou Zap70+ (BOMBEN et al., 2012). Portanto, a existência de sítios alvo dos microRNAs do cluster miR-17 92 nas regiões 3 '-UTR das variantes de DIDO poderia, em tese, ser a razão entre os níveis opostos de AURK e DIDO. Notoriamente, todas as três variantes apresentavam inúmeros sítios preditos para microRNAs expressos a partir da unidade transcricional do cluster miR-17 92.

Interessantemente, ao avaliarmos os níveis de E2F1 e MIR17HG nos subgrupos definidos pelos níveis alterados de expressão das AURKs e DIDO, ambos revelaram-se diretamente relacionados aos níveis de expressão das AURKs e inversamente aos níveis das variantes de DIDO, com as amostras com baixos níveis de DIDO apresentado níveis significativamente elevados para E2F1. Apesar dos níveis de MIR17HG não estarem significativamente mais altos no grupo com baixa expressão de DIDO1 ou DIDO2, sua expressão estava estritamente controlada numa faixa com níveis acima da maioria das amostras do grupo com níveis de DIDO normais. Como um todo, estes resultados fornecem indícios de que o eixo regulatório AURKA-E2F1-MIR17HG-DIDO poderia estar atuando.

Em linha, o knockdown de AURKA por siRNA (utilizando a linhagem NTERA2 como modelo) levou a uma redução significativa de nos níveis de E2F1 e de MIR17HG aos 3 e 5 dias pós-transfecção. Ainda, apesar de apresentarem uma leve, porém significativa, redução em seus níveis no terceiro dia pós-transfecção, as variantes DIDO2 e DIDO3 já apresentavam níveis elevados no quinto dia, dando indícios de um potencial acúmulo em andamento. Esta análise do silenciamento da AURKA por meio da transfecção dos siRNAs, gerando efeitos subsequentes sobre as variantes de DIDO, é de difícil interpretação devido ao fato do efeito esperado depender de toda a dinâmica temporal dos efeitos intermediários decorrentes do knockdown e do efeito transiente do siRNA. Apesar disto, tendo em vista a redução significativa dos mRNAs de E2F1 e MIR17HG, ao 3 e 5 dias pós-silenciamento da AURKA, estes resultados estariam em linha com o mecanismo proposto.

Importantemente, nosso grupo demonstrou anteriormente que as Auroraquinases $A$ e B são expressas em níveis mais elevados em células proliferativas da LLC localizadas na medula óssea e; adicionalmente, que células de LLC derivadas de casos mais agressivos (com genes IGHV não-mutados) respondem a estímulos 
com oligos- $\mathrm{CpG}$, com aumentos mais proeminentes de expressão de AURKA e AURKB e de proliferação (DE PAULA CARETA et al., 2012). Ainda, colaboradores demonstraram que miRNAs do cluster miR-17 92 também têm seus níveis induzidos em células de LLC estimuladas com oligos CpG, e que LLCs de pior prognóstico (genes IGHV não-mutados ou Zap70+) tem a expressão elevada destes microRNAs, em relação aos casos de bom prognóstico (BOMBEN et al., 2012). Ainda, células estromais e o ligante de CD40 (CD154), conhecido por fornecer sinais de proliferação e sobrevivência para células de LLC, também induzem a expressão do cluster miR-17 92 em células de LLC (WILLIMOTT; WAGNER, 2012).

Em linha com o mecanismo proposto por nós, estes estudos fornecem indícios da relação entre a indução das AURKs e do cluster miR-17 92, bem como entre a expressão do cluster e a proliferação na LLC, em linha com o amplo e importante papel dos microRNAs deste cluster na tumorigênese (MOGILYANSKY; RIGOUTSOS, 2013). Importantemente, a expressão forçada do cluster miR-17 92 especificamente em linfócitos $B$ em camundongos transgênicos, resulta em alterações proliferativas em $80 \%$ dos animais, resultando em leucemias com características de LLC agressiva (CD19+CD5+), assim como linfomas (SANDHU et al., 2013). Interessantemente, o grupo de Jin e colaboradores, além de demonstrar o papel do miR-17 92 na geração de neoplasias de células $B$ em camundongos transgênicos, identificou os genes alvo dos miRs deste cluster (utilizando PAR-clipe), demonstrando que a supressão de múltiplos alvos (incluindo reguladores negativos das vias de PI3K e NFkappaB) associados à super-expressão deste cluster levam à inibição da via de apoptose mitocondrial e à ativação das vias PI3K e NFkappaB (JIN et al., 2013).

De forma a avaliar se alguns dos microRNAs do cluster miR-17 92 poderiam estar, de fato, regulando os níveis das variantes de DIDO, utilizamos a mesma linhagem para realizar a transfecção de microRNAs miméticos selecionados, avaliando os níveis das diferentes variantes de DIDO, em seguida. Notavelmente, no quinto dia pós-transfecção, os miRs-19a, -20a e -92a levaram a uma redução robusta e estatisticamente significativa nos níveis dos transcritos de todas as três variantes de DIDO; o mesmo ocorrendo para o miR-18a em relação a DIDO1. Por outro lado, ao terceiro dia pós-transfecção, de maneira geral nenhum dos 
microRNAs causou uma redução significativa. Intrigantemente, aos 3 dias póstransfecção, apesar de todas as três variantes terem um sítio para o miR-18a, somente DIDO1 teve seus níveis reprimidos por este miR. Por outro lado, DIDO1 foi reprimido pelos miRs miR-19a e miR-20a mesmo sem ter sítios alvos preditos em seu transcrito, o mesmo ocorrendo para DIDO2 (que não possui sítios para o miR92a) e para DIDO3 (que não possui sítios alvo para o miR-19a e miR-92a).

Apesar da falta de efeito dos microRNAs sobre os níveis dos transcritos alvo preditos, aos 3 dias pós-transfecção, indicar que estes alvos provavelmente não sofrem uma desestabilização de seus transcritos, isto não exclui que eles possam ser alvos efetivos destes microRNAs, sofrendo exclusivamente um bloqueio de sua tradução proteica, sem sofrer efeito ao nível dos transcritos. Infelizmente, os experimentos preliminares (por Western Blotting), visando avaliar a potencial repressão da tradução proteica das isoformas de DIDO por microRNAs miméticos pertencentes ao cluster miR-17 92, não foram conclusivos. Ainda, apesar da repressão nos níveis das diferentes variantes, aos cinco dias pós-transfecção, poder ser um resultado da desestabilização tardia dos transcritos, a experiência de nosso grupo com este tipo de avaliação argui contra este mecanismo, uma vez que a desestabilização direta mediada por microRNAs ocorre em geral entre 48 e $72 \mathrm{~h}$ póstransfecção.

Embora estes resultados não esclareçam se uma regulação direta (dos microRNAs sobre os transcritos) poderia ser responsável por parte dos resultados observados, eles evidenciam claramente a existência de um mecanismo de regulação das variantes de DIDO downstream aos microRNAs do cluster miR17 92. Assim, algum outro mecanismo indireto poderia contribuir para a robusta redução nos níveis das variantes de DIDO, observada no quinto dia pós-transfecção.

Surpreendentemente, ao avaliarmos o efeito do knockdown específico das diferentes variantes de DIDO, sobre os níveis das demais, acabamos revelando um mecanismo regulatório de $\mathrm{DIDO} 3$ sobre as demais variantes. Claramente, 0 knockdown de DIDO3 levou a uma redução precoce de DIDO1 e DIDO2 aos 3 dias pós-transfecção. Tal regulação poderia ser explicada por um mecanismo semelhante à proteína homóloga BYE1 (Bypass of Ess1). Neste cenário, DIDO3 seria recrutado 
através de seu domínio PHD, para promotores de regiões transcricionalmente ativas, pela interação com domínios H3K4me3 nas etapas iniciais da transcrição. Uma vez interagindo com a polimerase Pol II-III por meio de seu domínio TFIIS-like, DIDO3 se ligaria diretamente à maquinaria transcricional, modulando positivamente sua progressão ao longo do gene (KINKELIN et al., 2013; PINSKAYA et al., 2014). A atuação conjunta de um mecanismo pós-transcricional direto de alguns microRNAs do cluster miR-17 92 levando a uma redução nos níveis de DIDO3, somada à regulação transcricional de DIDO3 sobre todos os transcritos do locus, poderia portanto, explicar os achados observados por nós, tanto nas amostras de pacientes, como nos experimentos in vitro.

Embora nossos achados, somados às evidencias da literatura, forneçam fortes indícios da existência do eixo regulatório AURKA-E2F1-MIR17HG-DIDO e de sua associação com a instabilidade cromossômica, é de grande relevância a questão de quais mecanismos seriam inicialmente responsáveis pelos aumentos dos níveis das Aurora-quinases. Neste contexto, o sequenciamento do genoma completo realizado em amostras de LLC permitiu a identificação de inúmeras mutações em genes codantes de componentes de diversas vias de sinalização, incluindo NOTCH1, SF3B1, ATM, TP53, BIRC3, POT1, XPO1 e KRAS (HERLING, C. D. et al., 2016; PUENTE et al., 2011). Importantemente, mutações ativadoras em KRAS e inativadoras de $P 53$ foram associadas à falta de resposta ao tratamento; enquanto, mutações em POT1, uma shelterina critica para o "capping" dos telômeros e para o recrutamento da telomerase, foram associadas a sobrevivência diminuida (HERLING, C. D. et al., 2016), em linha com outro estudo prêvio (RAMSAY et al., 2013). Digno de nota, a complexidade cariótipica e anormalidades em TP53 impactam o prognóstico na LLC de forma independente (HERLING, C. D. et al., 2016). Ainda, muitas das mutações identificadas na LLC estão relacionadas à sinalização do receptor de células $B$, com participação da via PI3K (GUIEZE; WU, 2015). Interessantemente, tanto a via PI3K/AKT (YANG, J. et al., 2014) como a via RAS (YANG, G. et al., 2013) podem promover a instabilidade genômica pela indução e ativação de Aurora-quinase A e AURKB, causando poliploidia ou aneuploidias cromossômicas. 
Juntos, estes indícios suportam um cenário onde diferentes alterações genéticas primárias poderiam levar a um aumento de expressão das Auroraquinases e consequentemente, a uma indução do cluster do miR-17 92 que, em ultima instância, levaria a uma redução nos níveis de DIDO e à instabilidade cromossômica associada à presença de cariotipos complexos nas LLCs de pior prognóstico. Tendo em vista que a super-expressão do cluster miR-17 92 em células $B$ de camundongos resulta em neoplasia, com à inibição da via de apoptose mitocondrial e a ativação das vias PI3K e NFkappaB (JIN et al., 2013), isto poderia caracterizar um feedback positivo, com a via PI3K induzindo as Auroras e consequentemente, a expressão do cluster via E2F1. Curiosamente, a família E2F, descrita por regular diversas funções celulares, como reparo à danos no DNA, duplicação dos centrossomos e progressão do ciclo celular, e o próprio E2F1 também é alvo do miR-17a e miR-20a do cluster miR-17 92, o que poderia caracterizar um mecanismo de feedback negativo de contraposição ao acúmulo anormal de E2F1 (O'DONNELL et al., 2005; SYLVESTRE et al., 2007), que no entanto, não seria suficiente para contrapor a sinalização upstream alterada na LLC.

Isto colocaria as alterações nos níveis de expressão das AURKs e de DIDO num ponto de convergência central e poderia indicar que a avaliação dos níveis de expressão destes dois únicos genes poderia permitir uma classificação facilitada de um subgrupo de mal prognóstico na LLC, caracterizado por um circuito retroalimentado de instabilidade genômica. A confirmação disto, no entanto, depende da avaliação num coorte maior e extensamente caracterizado, como os de Herling e Thompson (HERLING, C. D. et al., 2016; THOMPSON et al., 2015).

Nosso resultados evidenciam uma associação entre níveis alterados de AURKs e DIDO com a ocorrência de aneuploidias, em especial, ganhos cromossomais. Estes achados teriam como base a eliminação de clones inviáveis apresentando perdas de cromossomos e a manutenção dos clones com ganhos cromossomais, que possuiriam uma vantagem proliferativa e/ou resistência à morte celular. Como mencionado, estas aneuploidias seriam derivadas provavelmente da amplificação centrossomal (decorrente dos níveis alterados de AURKs e de DIDO) com consequentes ligações monotélicas ou sintélicas, resultando em erros na segregação cromossômica. 
Importantemente, a amplificação centrossomal também pode levar à formação de ligações merotélicas, que resultam da ligação de microtúbulos de polos opostos a um único dos cinetócoros de cromátides irmãs, gerando estresse físico no centrômero e levando a quebras cromossômicas na região pericentromérica durante a anáfase, com o surgimento de translocações (GUERRERO; GAMERO; et al., 2010; GUERRERO; MARTINEZ; et al., 2010). As extremidades coesivas geradas com estas quebras podem se fundir a outras extremidades cromossômicas livres, com consequente formação de pontes e quebras cromossômicas, durante a separação dos cromossomos na anáfase da divisão celular, um mecanismo denominado de Breakage-Fusion-Bridge (B/F/B). Evidências recentes, revelaram que em diversas neoplasias as quebras cromossômicas mais frequentes ocorrem em regiões pericentroméricas, indicando que o mecanismo $B / F / B$ teria como origem principal a fusão entre extremidades coesivas originadas em decorrência de ligações merotélicas não corrigidas no início da mitose; ao invés de fusões entre cromossomos com extremidades teloméricas erodidas, associadas a pontos de quebra distais (MARTINEZ; VAN WELY, 2011).

Apesar do mecanismo envolvendo as ligações merotélicas poder explicar as translocações e os ganhos cromossomais observados no subgrupo de LLCs com expressão alterada de AURK e DIDO, as aberrações citogenéticas não-numéricas encontradas no subgrupo de LLCs com níveis de AURKs e DIDO normais (similares às LLCs ou controles com citogenética normal) teriam uma origem provavelmente distinta. Neste contexto, o mecanismo responsável pelas translocações poderia envolver a erosão dos telômeros, frequentemente ocasionada por alterações tanto da enzima responsável por sua manutenção (telomerase) como do complexo proteico responsável por sua proteção (shelterinas), resultando em aberrações, como deleções, inversões e translocações, ao longo de diversas divisões celulares (MURAKI et al., 2012; MURNANE, 2012). A princípio, eventos iniciais de fusão de cromátides irmãs produziriam apenas duplicações ou deleções de segmentos cromossômico terminais nas células filhas, porém, com o encurtamento progressivo dos telômeros, ocorreriam eventos de fusão intercromossômicos, produzindo translocações não-balanceadas (TUSELL et al., 2008). 
Telômeros curtos em células da LLC estão associados à presença de aberrações cromossômicas e uma sobrevida diminuida (ROOS et al., 2008), no entanto, não é claro se o encurtamento telomérico seria a causa das anomalias cromossômicas, ou se seria a consequência das mesmas, tendo em vista que a proliferação aumentada levaria consequentemente a uma redução dos telômeros (JAHRSDORFER; WEINER, 2008). Um estudo posterior, no entanto, forneceu indícios de que, pelo menos em alguns casos, o encurtamento telomérico poderia preceder a instabilidade cromossômica (LIN et al., 2010). Apesar do papel causal do encurtamento telomérico, em relação à instabilidade cromossômica na LLC, ter um papel bem estabelecido nos casos apresentando mutações no gene POT1 componente do complexo da shelterina (RAMSAY et al., 2013), e do mesmo ser considerado um marcador confiável de mal prognóstico, mesmo em casos iniciais da doença (LIN et al., 2014), nossos achados arguem a favor de pelo menos dois mecanismos de instabilidade cromossomica na LLC. Assim, enquanto os erros de ligação ao fuso, seria a principal causa dos ganhos cromossomais no subgrupo de LLCs caracterizado pela expressão alterada de AURK e DIDO, a erosão telomerica seria a principal causa na origem das aberrações cromossômicas não-numéricas observadas nas LLCs restantes, além de potencialmente contribuir para a instabilidade cromossômica no subgrupo com ganhos cromossomais.

Apesar de não ser o alvo direto de nosso estudo, o compartilhamento do promotor de GID8 com DIDO indicam que os papéis destes genes estão relacionados funcionalmente. A proteína GID8 foi caracterizada funcionalmente após a identificação de sua interação com a proteína RANBPM (RANBP9), pelo uso do método de duplo híbrido, motivo pelo qual foi nomeada Two-Hybrid-Associated Protein with RANBPM1, ou TWA1 (UMEDA; NISHITANI; NISHIMOTO, 2003). A região $\mathrm{N}$-terminal de TWA1 possui um domínio LISH (homologo a Lis1) e um domínio CTLH (C-terminal a LISH), que é encontrado em proteínas envolvidas na dinâmica dos microtúbulos, na migração celular, nucleocinese e segregação cromossômica (EMES; PONTING, 2001); além de possuir um domínio C-terminal semelhante a um domínio C-terminal na própria proteína RANBPM, com a qual interage (UMEDA et al., 2003). A proteína TWA1 forma um complexo com RANBPM e outras proteínas (incluindo Muskelin), recebendo o nome de complexo CTLH 
(KOBAYASHI et al., 2007) o qual, após recrutamento de SOS, ativa a via de sinalização das MAP quinases (RAS/RAF/MEK/ERK/MAPK). Apesar de TWA1 não ter sua função bem definida, RANBPM foi descrito como uma proteína com atividade pró-apoptótica em resposta a danos do DNA (ATABAKHSH et al., 2009), além de ser essencial para a espermatogênese e oogênese em camundongos (PUVEREL et al., 2011). Mais recentemente, a análise filogenética molecular dos componentes do complexo CTLH, revelou que TWA1 seria um gene ortólogo a GID8 de S. cerevisiae (FRANCIS; HAN; ADAMS, 2013), levando à renomeação do gene de TWA1 para GID8. O compartilhamento do promotor de GID8 com DIDO e a presença de domínios estruturais semelhantes aos encontrados em proteínas envolvidas na segregação cromossômica, indicam fortemente que os papéis de DIDO e GID8 sejam inter-relacionados funcionalmente, bem como temporalmente, uma vez que suas expressões provavelmente ocorreriam de forma sincrônica. De fato, o padrão de expressão de GID8 nas amostras de controles e pacientes se assemelha muito com o de DIDO1 e com o perfil obtido com o primer desenhado para identificar os transcritos de DIDO transcritos a partir do início de transcrição associado a este promotor compartilhado. Finalmente, GID8 sofre o mesmo efeito que as variantes de DIDO, mediante a repressão de AURKA por siRNA na linhagem NTERA-2. Isto nos leva a sugerir que que DIDO e GID8 tem suas funções intimamente ligadas e que alterações em GID8 também contribuiriam para a instabilidade cromossômica no subgrupo com expressão alterada de AURKs e DIDO. 
Estudos recentes demonstraram que, nas células B da LLC, a instabilidade cromossômica como um todo, e não apenas alterações genéticas pontuais, teriam um papel importante na fisiopatologia da LLC, contribuindo não apenas para a progressão para sub-tipos mais agressivos da doença, mas para sua própria gênese. Estes achados revelam a importância do entendimento dos mecanismos moleculares envolvidos na instabilidade cromossômica observada na LLC.

Nossos resultados vão ao encontro desses achados, uma vez que nós identificamos, de forma inédita, um subgrupo de pacientes que apresentam uma clara associação entre níveis alterados de AURKs e DIDO com ganhos cromossomais e contagens de glóbulos brancos aumentadas (um indicativo de mal prognóstico independente em análises multivariadas).

Como discutido, estes achados se devem provavelmente à amplificação centrossomal (decorrente dos níveis alterados de AURKs e de DIDO) e às consequentes ligações monotélicas ou sintélicas, que resultam em erros na segregação cromossômica e no surgimento de clones aneuploides. Durante a evolução da doença, os clones com ganhos cromossomais seriam mantidos por possuírem vantagens adaptativas (proliferativa e/ou resistência à morte celular); enquanto, os clones inviáveis, apresentando perdas de cromossomos, seriam eliminados.

A amplificação centrossomal também pode levar à formação de ligações merotélicas (ligação de microtúbulos de polos opostos a um único dos cinetócoros de cromátides irmãs), levando a quebras na região pericentromérica com o surgimento de translocações. Apesar deste mecanismo explicar as translocações e os ganhos cromossomais observados no subgrupo com expressão alterada de AURK e DIDO, as aberrações citogenéticas não-numéricas encontradas no subgrupo com níveis normais destes genes teriam uma origem distinta. Neste subgrupo, o mecanismo poderia envolver a erosão dos telômeros, resultando em aberrações, como deleções, inversões e translocações; em linha com os estudos que demonstram uma associação de telômeros curtos com a presença de aberrações cromossômicas e uma sobrevida diminuida. 
Nossos achados arguem a favor de pelo menos dois mecanismos de instabilidade cromossômica na LLC. Assim, enquanto os erros de ligação ao fuso, seria a principal causa dos ganhos cromossomais no subgrupo de LLCs caracterizado pela expressão alterada de AURK e DIDO; a erosão telomérica seria a principal causa na origem das aberrações cromossômicas não-numéricas observadas nas LLCs restantes, além de potencialmente contribuir para a instabilidade cromossômica no subgrupo com ganhos cromossomais.

Finalmente, nossos resultados fornecem indícios de que o eixo regulatório AURKA-E2F1-MIR17HG-DIDO poderia estar atuando no subgrupo de LLCs com ganhos cromossomais. Tendo em vista os indícios de que diferentes alterações genéticas primárias associadas com LLC de mal prognóstico poderiam resultar no aumento de expressão e atividade das Aurora-quinases, as alterações nos níveis de expressão das AURKs (e consequentemente de DIDO) representariam um ponto de convergência central. Isto pode indicar que a avaliação dos níveis de expressão destes dois únicos genes poderia permitir a classificação facilitada de um subgrupo de mal prognóstico na LLC, caracterizado por instabilidade genômica acentuada e cariótipos complexos. 


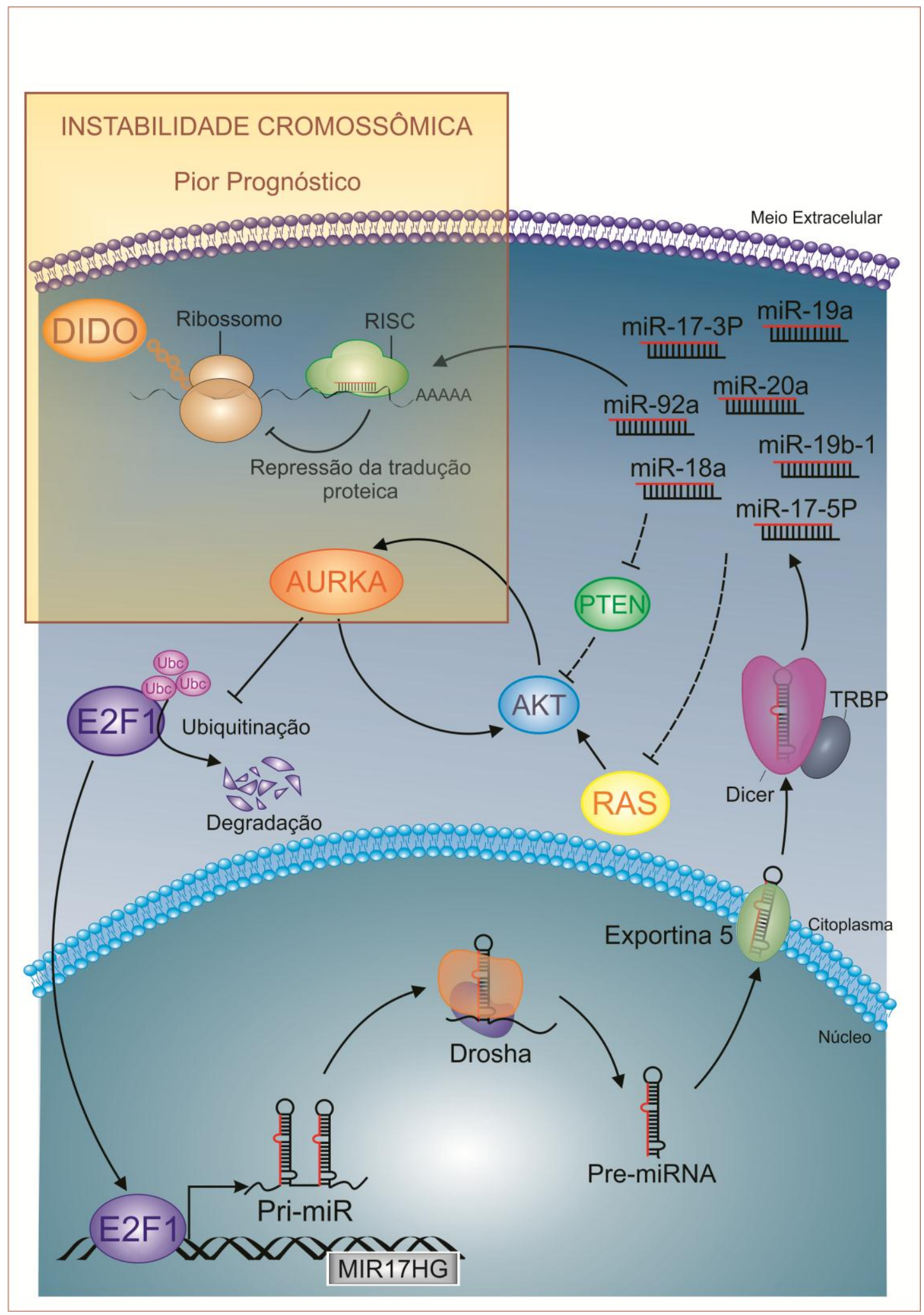

FIGURA 35. Proposta de via regulatória entre AURKA e DIDO. Mecanismo regulatório sobre as variantes de DIDO ocorrendo downstream aos microRNAs do cluster miR-17 92, os quais são regulados indiretamente por meio de níveis de expressão de AURKA. 
7.ANEXOS 


\section{Silenciamento inespecífico dos siRNAs contra as variantes} de DIDO

A figura 36 retrata a inespecificidade dos siRNAs contra os alvos preditos de DIDO obtidos pela empresa Life Technologies, atualmente Thermo Scientific. Resultados semelhantes de redução dos níveis de expressão foram obtidos, também, para os transcritos de DIDO2 e DIDO3. Análises de especificidade com siRNAs contra transcritos de AURKA, AURKB e GID8 foram, contudo, positivas.

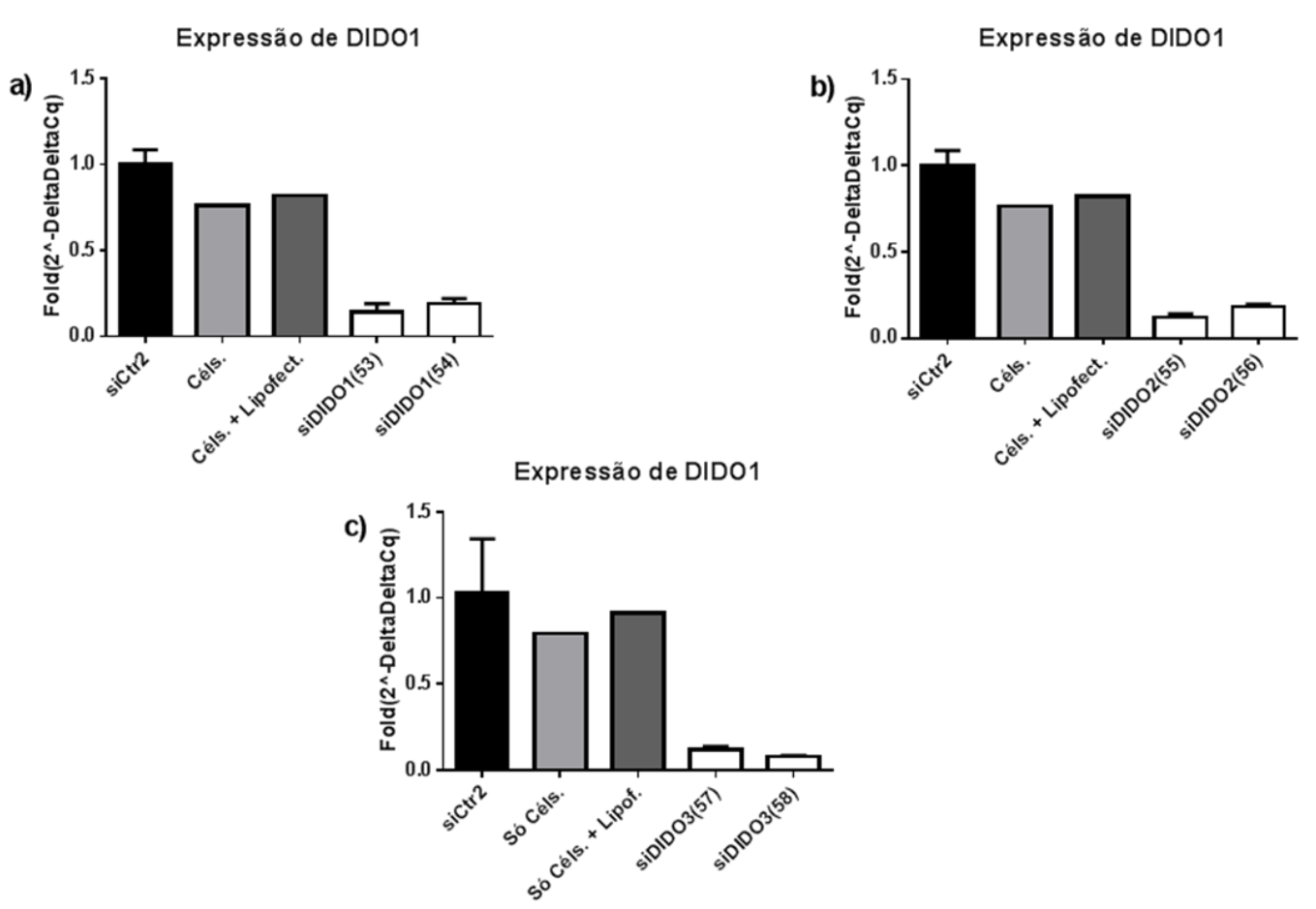

FIGURA 36. Inibição inespecífica de DIDO1 por siRNAs supostamente específicos contra as outras variantes. Os resultados representam os níveis do mRNA de DIDO1 48 horas após a transfecção da linhagem BJ de fibroblastos com siRNAs contra diferentes variantes de DIDO. a) Expressão de DIDO1 pós-transfecção com siDIDO1; b) Expressão de DIDO1 pós-transfecção com siDIDO2; c) Expressão de DIDO1 pós-transfecção com siDIDO3. Grupos transfectados, em triplicata. Os valores foram normalizados pela expressão de GAPDH $(\Delta \mathrm{Ct})$. A expressão relativa das amostras foi calculada utilizando a expressão média do grupo siCtr2 como referência (2- $\Delta \Delta \mathrm{Ct})$.

Tendo em vista que os resultados prévios de expressão das variantes transcricionais de DIDO não se enquadram com os desenhos das sequências de siRNAs específicos, representado pela figura 36 , uma análise detalhada das 
sequências obtidas pelos datasheet dos produtos, por meio da plataforma digital BLAT, foi realizada sendo representada pela figura 37 , abaixo.

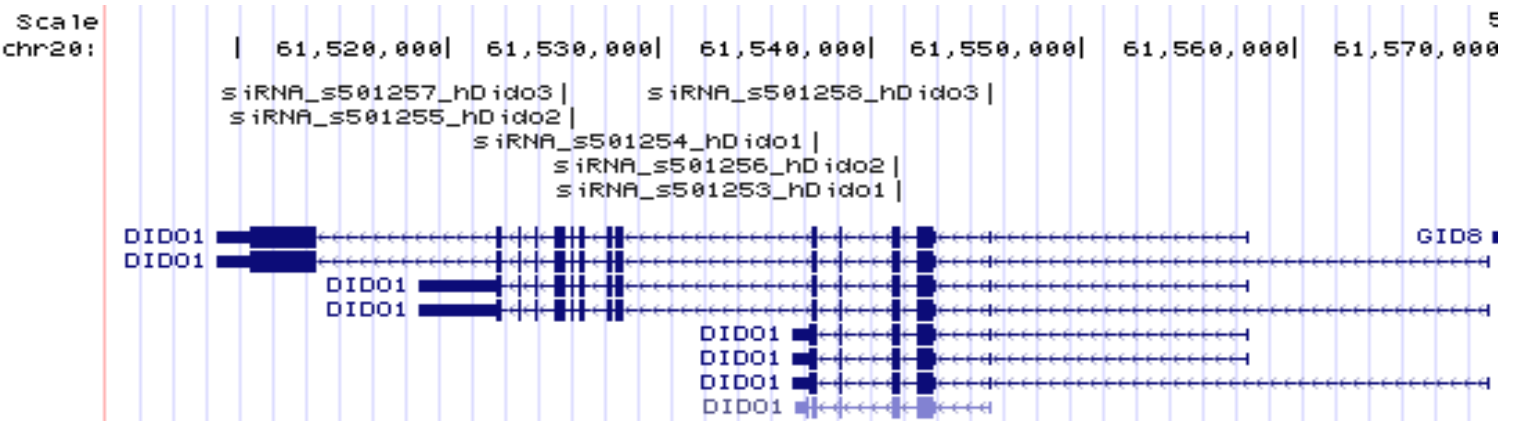

FIGURA 37. Sequências dos siRNAs compartilhados com as variantes transcricionais de DIDO em exons inespecíficos.

Tal análise nos levou a requerer uma retratação por parte da empresa visando a correção das sequências dos siRNAs contra transcritos de DIDO. Assim, novos siRNAs, cujas sequências estão representadas na figura 30 , foram desenhados em exons específicos à cada variante de DIDO, os quais foram sintetizados e encaminhados ao nosso laboratório.

\section{Número de cromossomos em amostras de SMD de pacientes com citogenética aberrante}

Após análises das variantes estudadas quanto à expressão em amostras de pacientes com SMD, é possível inferirmos ausência de correlação entre os níveis de expressão de tais transcritos com possíveis variações do número de cromossomos encontrados indicando, dessa forma, a presença de outros mecanismos envolvidos na instabilidade cromossômica além dos que foram abordados relacionando os centrossomos e microtúbulos do fuso, durante a divisão celular. Assim, pode-se pressupor que tais variações citogenéticas advêm de alterações na estabilidade telomérica decorrente, eventualmente, da atividade de sua enzima precursora (telomerase) que, por consequência, gera um mecanismo cíclico conhecido como Breakage-Fusion-Bridge (B/F/B) acarretando aberrações cromossômicas após muitas divisões celulares, como deleções, inversões e/ou translocações. 


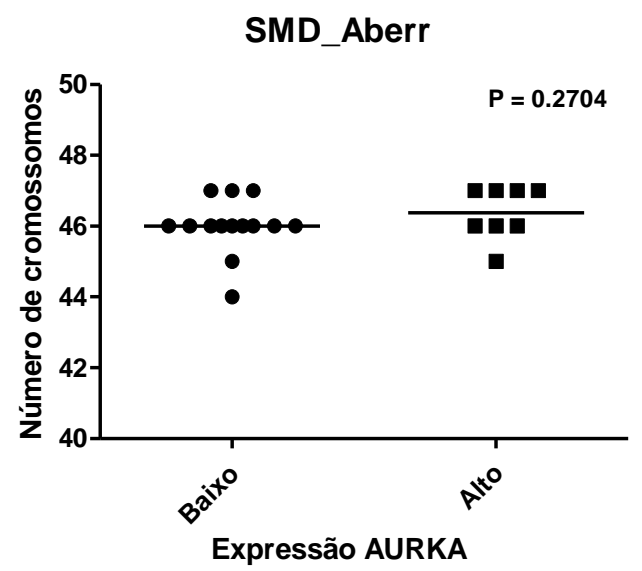

SMD_Aberr

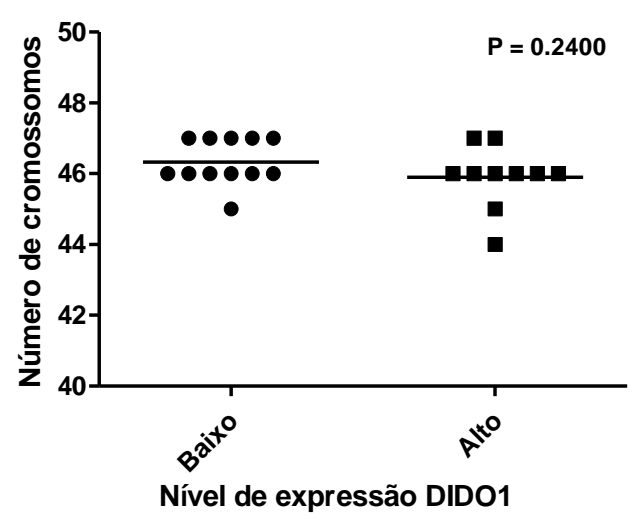

SMD_Aberr

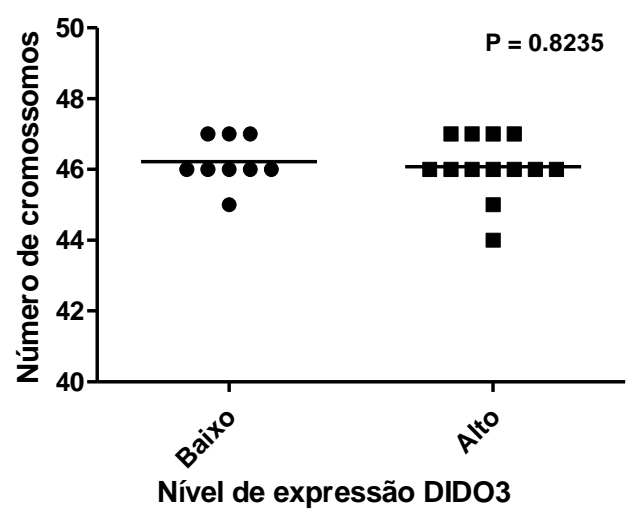

SMD_Aberr

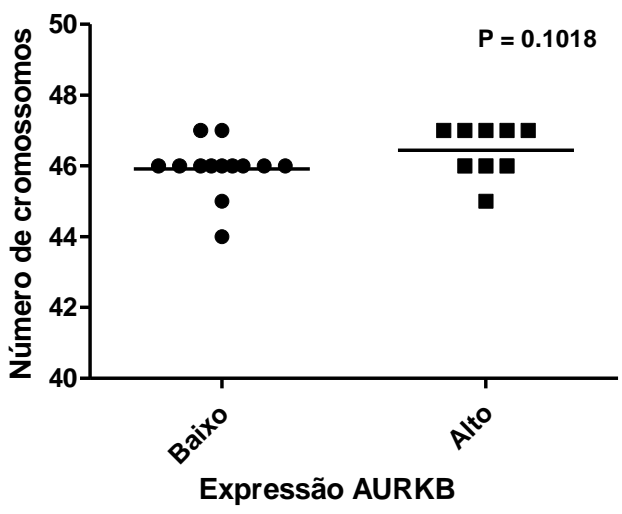

SMD_Aberr

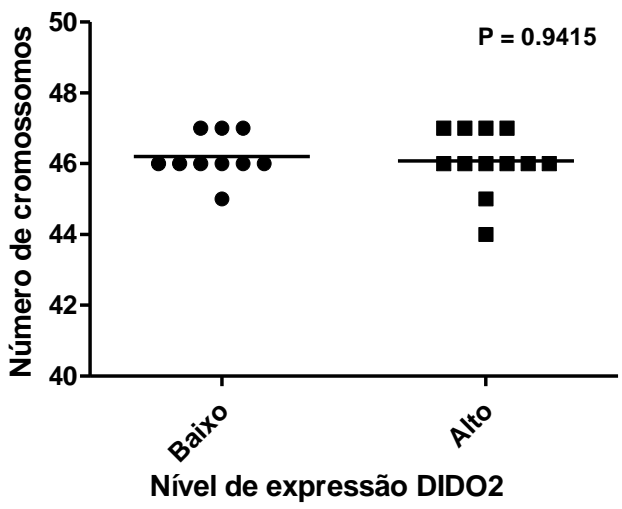

SMD_Aberr

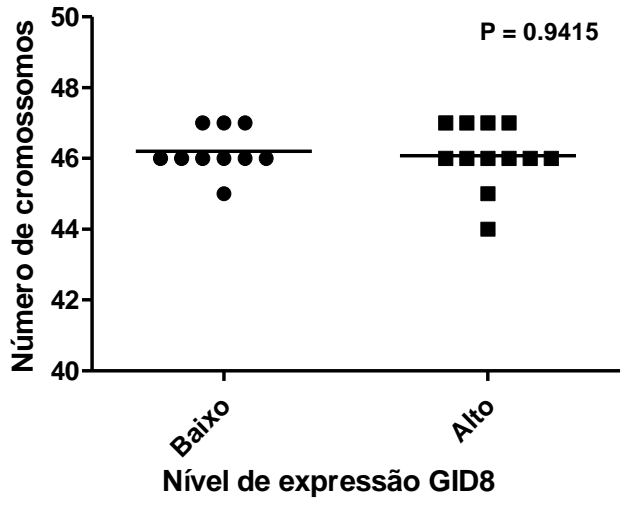

FIGURA 38. Contagem do número total de cromossomos, na análise do cariótipo, comparadas quanto aos grupos de SMD aberrante (SMD_Aberr) que expressam níveis elevados ou baixos dos transcritos estudados. A variação dos níveis de expressão de tais transcritos sobre as amostras de SMD aberrante não teve interferência sobre o número de cromossomos. ${ }^{*} 0.01<p<$ $0.05 ;{ }^{* *} 0.001<p<0.01 ;{ }^{* * *} p<0.001$. 
TABELA 5. AMOSTRAS DE PACIENTES COM SMD

\begin{tabular}{|c|c|c|c|c|c|}
\hline Amostra & Iniciais & Gênero & WBC (mm3) & Linf & Citogenética \\
\hline 1 & HAC & $M$ & 2800 & 1200 & $47, \mathrm{XY},+4[2] / 46, \mathrm{XY}[18]$ \\
\hline 2 & SPG & $\mathrm{F}$ & 7400 & 2300 & $46, \mathrm{XX}[20]$ \\
\hline 3 & MAR & $\mathrm{F}$ & 2300 & 300 & $46, X X, \operatorname{del}(7)(q 22 q 36)[3] / 46, X X[13]$ \\
\hline 4 & JCA & $\mathrm{F}$ & 1900 & 600 & $46, X X[18]$ \\
\hline 5 & AT & $\mathrm{F}$ & 4400 & 2100 & $46, X X, \operatorname{inv}(3)(q 21 q 26)[3] / 46, X X[13]$ \\
\hline 6 & JOL & $\mathrm{M}$ & 5200 & 1600 & $46, X Y$, add $(17)(p 12)[4] / 46, X Y[16]$ \\
\hline 7 & MASS & $\mathrm{F}$ & 4400 & 1200 & $47, X X,+15[4] / 46, X X[12]$ \\
\hline 8 & JCS & $\mathrm{M}$ & 3000 & 1800 & $46, X Y[16]$ \\
\hline 9 & ZCC & $\mathrm{F}$ & 4000 & 2200 & $44, \mathrm{XX},-4[3], \operatorname{del}(7)(\mathrm{p} 15)[2], \operatorname{del}(12)(\mathrm{p} 12)[3] / 46, \mathrm{XX}[10]$ \\
\hline 10 & RB & $\mathrm{F}$ & 4500 & 1200 & $46, X X, \operatorname{del}(5)(q 31)[4] / 46, X X[11]$ \\
\hline 11 & AAXP & $\mathrm{F}$ & 3900 & 2900 & $46, \mathrm{XX}[18]$ \\
\hline 12 & GFV & $\mathrm{F}$ & 4000 & 1700 & $46, X X, \operatorname{dup}(1)(q 32 q 21)[3] / 46, X X[17]$ \\
\hline 13 & MJFS & $\mathrm{F}$ & 6200 & 1400 & $46, X X[20]$ \\
\hline 14 & $\mathrm{ClJ}$ & $\mathrm{M}$ & 3600 & 1400 & $45-46, X,-Y[6], \operatorname{del}(17)(p 12)[4] / 46, X Y[12]$ \\
\hline 15 & MB & $\mathrm{M}$ & 7300 & 1300 & $46, X Y[20]$ \\
\hline 16 & $\mathrm{AM}$ & $\mathrm{M}$ & 4400 & 2200 & $46, X Y, \operatorname{del}(20)(q 11)[4] / 46, X Y[11]$ \\
\hline 17 & OF & $\mathrm{M}$ & 3000 & 800 & $46, X Y, \operatorname{del}(13)(q 12 q 14)[6] / 46, X Y[12]$ \\
\hline 18 & MSBO & $\mathrm{F}$ & 8200 & 3700 & $46, \mathrm{XX}[13]$ \\
\hline 19 & BSL & $\mathrm{F}$ & 6100 & 2300 & $46, X X[20]$ \\
\hline 20 & APM & $\mathrm{F}$ & 6800 & 1700 & $46, \mathrm{XX}, \operatorname{del}(20)(q ?)[8] / 46, \mathrm{XX}[10]$ \\
\hline 21 & IBP & $\mathrm{F}$ & 3600 & 174 & $46, X X[17]$ \\
\hline 22 & VLCLP & $\mathrm{F}$ & 4400 & 2100 & $46, \mathrm{XX}[16]$ \\
\hline 23 & AM & $\mathrm{M}$ & 6100 & 1600 & $46, X Y[14]$ \\
\hline 24 & GFR & $\mathrm{F}$ & 4000 & 1500 & $46, X X[20]$ \\
\hline 25 & MCS & $\mathrm{F}$ & 4600 & 1500 & $46, \mathrm{XX}[18]$ \\
\hline
\end{tabular}




\begin{tabular}{|c|c|c|c|c|c|}
\hline Amostra & Iniciais & Gênero & WBC (mm3) & Linf & Citogenética \\
\hline 26 & $\mathrm{CP}$ & $\mathrm{F}$ & 2400 & 1400 & $46, \mathrm{XX}[14]$ \\
\hline 27 & IVS & M & 2800 & 1600 & $46, \mathrm{XY}[17]$ \\
\hline 28 & RMCOG & $\mathrm{F}$ & 2900 & 1500 & $46, X X, \operatorname{del}(7)(q 22)[5] / 46, X X[15]$ \\
\hline 29 & $\mathrm{KI}$ & $\mathrm{M}$ & 4300 & 700 & $47, \mathrm{XY},+8[6] / 46, \mathrm{XY}[8]$ \\
\hline 30 & RSR & $\mathrm{F}$ & 2600 & 1400 & $46, \mathrm{XX}[18]$ \\
\hline 31 & JFC & $\mathrm{M}$ & 2700 & 1200 & $46, X Y[20]$ \\
\hline 32 & CFLN & $\mathrm{F}$ & 10600 & 2900 & $45, X X,-9[4] / 46, X X[16]$ \\
\hline 33 & DSR & $\mathrm{F}$ & 3200 & 1400 & $46, \mathrm{XX}[18]$ \\
\hline 34 & ANA & $\mathrm{M}$ & 2700 & 6200 & $47, X Y+4[4] / 46, X Y[16]$ \\
\hline 35 & ADP & $\mathrm{F}$ & 4200 & 1900 & $46, X X, \operatorname{del}(20)(q 11)[7] / 46, X X[13]$ \\
\hline 36 & TTC & $\mathrm{M}$ & 2400 & 4810 & $47-48, X Y,+5[3],+\operatorname{del}(8)(q 21)[4] / 46, X Y[12]$ \\
\hline 37 & BSP & $\mathrm{F}$ & 1700 & 4070 & $46, X X[15]$ \\
\hline 38 & $\mathrm{CL}$ & $\mathrm{F}$ & 3200 & 1000 & $47, X X,+9[6] / 46, X X[14]$ \\
\hline 39 & FBGT & $\mathrm{M}$ & 4900 & 2360 & $46, X Y[20]$ \\
\hline 40 & JAS & $\mathrm{F}$ & 3000 & 2050 & $46, X X[15]$ \\
\hline 41 & MAR & $\mathrm{F}$ & 2300 & 1410 & $46, X X, \operatorname{del}(7)(q 22 q 36)[3] / 46, X X[13]$ \\
\hline 42 & MMSB & $\mathrm{F}$ & 1140 & 3100 & $46, X X, \operatorname{inv}(3)(q 21 q 26)[6] / 46, X X[14]$ \\
\hline 43 & TMSM & $\mathrm{F}$ & 9600 & 4540 & $47, X X,+8[4] / 46, X X[11]$ \\
\hline
\end{tabular}


TABELA 6. AMOSTRAS DE PACIENTES COM LLC

\begin{tabular}{|c|c|c|c|c|c|c|c|}
\hline Amostra & Iniciais & Gênero & Idade & ZAP 70+ (\%) & WBC (mm3) & Linf (\%) & Citogenética \\
\hline 1 & NCSP & $\mathrm{F}$ & 59 & 41.16 & 43700 & 86.4 & $46, \mathrm{XX}, \operatorname{del}(12)(\mathrm{p} 13)[2], \operatorname{del}(17)(\mathrm{p} 13)[2] / 46, \mathrm{XX}[16][\mathrm{cp} 4]$ \\
\hline 2 & $\mathrm{BP}$ & $\mathrm{M}$ & 52 & 85.16 & 14900 & 64.4 & $46, X Y, t(14 ; 18)(q 32 ; q 21)[18],-16[3] / 46, X Y[2][c p 18]$ \\
\hline 3 & JGN & $\mathrm{M}$ & 65 & 69.06 & 22100 & 61.0 & $47, X Y,+21[20][c p 20]$. \\
\hline 4 & LAC & $\mathrm{F}$ & 59 & 0.98 & 7800 & 79.3 & $46, X X[20]$. \\
\hline 5 & LCDS & M & 43 & 22.4 & 13100 & 60.8 & $46, X Y[20]$ \\
\hline 6 & MRN & $\mathrm{F}$ & 67 & 6.22 & 42800 & 78.3 & 46,XX,del(11)(q13 q23)[15]/46,XX[5][cp15]. \\
\hline 7 & EF & $\mathrm{M}$ & 55 & 13.88 & 57300 & 72.0 & $46, X Y[20]$ \\
\hline 8 & CMDC & $\mathrm{F}$ & 44 & 17.3 & 30100 & 81.5 & $46, X X[20]$ \\
\hline 9 & $\mathrm{TAO}$ & $\mathrm{M}$ & 54 & 18.2 & 24100 & 79.2 & $46, X Y[20]$ \\
\hline 10 & $\mathrm{JZ}$ & $\mathrm{M}$ & 74 & 26.99 & 170100 & 98.0 & 47,XY,+12[20],del(14)(q24)[20][cp20]. \\
\hline 11 & MTT & $\mathrm{F}$ & 43 & 47.00 & 11300 & 88.3 & $46, X X, t(1 ; 12)(q 31 ; p 13)[20][c p 20]$ \\
\hline 12 & ESC & $\mathrm{F}$ & 56 & NR & 81200 & 71.9 & $45, X X, t(11 ; 13)(q 23 ; q 12)[15] / 46, X X[5][c p 15]$ \\
\hline 13 & BLS & $\mathrm{F}$ & 73 & 46.33 & 21300 & 77.5 & $46, X X, \operatorname{del}(17)(p 13)[8] / 46, X Y[12][c p 8]$ \\
\hline 14 & FSU & $\mathrm{M}$ & 59 & 27.02 & 30800 & 71.5 & 46,XY,del(6)(q24)[16]/46,XY[4][cp16]. \\
\hline 15 & JPT & $\mathrm{M}$ & 66 & 19.6 & 147400 & 84.5 & $46, X Y[20]$ \\
\hline 16 & BT & $\mathrm{M}$ & 59 & 78.84 & 10500 & 57.9 & 46,XY,del(13)(q31)[13]/46,XY[7][cp13]. \\
\hline 17 & MBM & $\mathrm{F}$ & 56 & 14.5 & 49900 & 84.2 & $46, X X[20]$ \\
\hline 18 & MJZC & $\mathrm{F}$ & 67 & 17.22 & 71200 & 85.0 & $47, \mathrm{XX},+12[20][\mathrm{cp} 20]$ \\
\hline 19 & ALC & $\mathrm{M}$ & 70 & 12.5 & 17300 & 55.0 & $46, X Y[20]$ \\
\hline 20 & MNS & $\mathrm{M}$ & 76 & 79.6 & 67200 & 84.7 & $48, X Y,+8,+8[16] / 46, X Y[4][c p 16]$ \\
\hline 21 & AS & $\mathrm{M}$ & 64 & 32.76 & 52200 & 77.5 & $47, X Y,+4[12] / 46, X Y[8][c p 12]$ \\
\hline 22 & OCP & $\mathrm{F}$ & 62 & 5.34 & 25300 & 80.4 & $46, X X[20]$ \\
\hline 23 & CCSC & $\mathrm{F}$ & 55 & 2.33 & 45200 & 77.8 & $47, X X,+5[20]$ \\
\hline
\end{tabular}


TABELA 7. AMOSTRAS DE PACIENTES COM LLC (CONTINUAÇÃO)

\begin{tabular}{|c|c|c|c|c|c|c|c|}
\hline Amostra & Iniciais & Gênero & Idade & ZAP 70+ (\%) & WBC (mm3) & Linf (\%) & Citogenética \\
\hline 24 & $\mathrm{JC}$ & $\mathrm{M}$ & 49 & 16.94 & 21600 & 88.2 & $46, X Y[20]$ \\
\hline 25 & SR & $\mathrm{M}$ & 76 & 79.59 & 80400 & 68.3 & $46, X Y, t(11 ; 13)(q 23 ; q 12)[20]$. \\
\hline 26 & AFM & $\mathrm{M}$ & 67 & 28.04 & 46300 & 67.5 & $46, X Y, t(1 ; 10)(p 22 ; p 14)[10] / 46, X X[10][c p 10]$ \\
\hline 27 & ALBF & $\mathrm{F}$ & 73 & 8.57 & 23400 & 70.7 & $46, X X[20]$. \\
\hline 30 & $\mathrm{JC}$ & $\mathrm{M}$ & 80 & 27.42 & 43000 & 72.4 & $46, X Y, t(10 ; 13)(q 26 ; q 14)[14] / 46, X X[6][c p 14]$ \\
\hline 32 & MV & $\mathrm{M}$ & 67 & 57.4 & 29000 & 57.9 & $47, X Y,+21[20]$ \\
\hline 33 & EF & M & 56 & 12.69 & 34400 & 62.2 & $46, X Y[20]$ \\
\hline 34 & JDS & $\mathrm{M}$ & 54 & 15.79 & 43000 & 77.1 & $47, X Y,+12[11] / 46, X X[9][\mathrm{cp} 11]$ \\
\hline 35 & JBA & $\mathrm{M}$ & 77 & 34.45 & 54300 & 79.5 & 46,XY,del(5)(q14q32)[16]/46,XX[4][cp16]. \\
\hline 36 & LLC $01(\mathrm{MO})$ & M & 65 & 76.05 & 43100 & 65.2 & $47, X Y,+12[14] / 46, X Y[6][c p 14]$ \\
\hline 39 & LLC 04 (MLS) & $\mathrm{F}$ & 58 & 34.76 & 47100 & 71.3 & 46,XX,del(13)(q14q22)[12],del(18)(q12)[10]/46,XX[8][cp12]. \\
\hline 41 & LLC 05 (AAO) & $\mathrm{F}$ & 57 & 57.04 & 93500 & 73.7 & $49, X X,+12,+18,+19[14] / 46, X X[6][c p 14]$. \\
\hline 43 & LLC 07 (HMS) & $\mathrm{F}$ & 73 & 22.05 & 85300 & 68.9 & $49, X X,+9,+12,+18[17] / 46, X X[3][c p 17]$ \\
\hline 44 & LLC 08 (BBN) & $\mathrm{M}$ & 80 & 34.15 & 77100 & 78.3 & $48, X Y,+12,+19[12] / 46, X Y[8][\mathrm{cp} 12]$ \\
\hline 45 & LLC 09 (JC) & $\mathrm{M}$ & 69 & 44.30 & 65300 & 75.6 & $49, X Y,+16,+18,+21[16] / 46, X Y[4][c p 16]$ \\
\hline 46 & LLC 10 (ARP) & $\mathrm{F}$ & 53 & 67.22 & 119500 & 67.5 & $48, X X, \operatorname{del}(4)(q 11 q 21),+5,+9[14] / 46, X X[6][c p 14]$. \\
\hline 47 & LLC 11 (JPA) & $\mathrm{M}$ & 61 & 78.04 & 78300 & 78.5 & $50, X Y,+8,+12,+15,+18[20][c p 20]$ \\
\hline 48 & LLC 12 (AAQ) & $\mathrm{F}$ & 58 & 75.05 & 93200 & 83.5 & $47, \mathrm{XX},+12[8] / 46, \mathrm{XX}[12][\mathrm{cp} 8]$ \\
\hline 49 & LLC 13 (LAS) & $\mathrm{M}$ & 55 & 29.08 & 43500 & 92.4 & $47, X Y, t(14 ; 22)(q 32 ; q 11),+8[15] / 46, X Y[5][c p 15]$ \\
\hline 51 & LLC 15 (AFM) & $\mathrm{M}$ & 67 & 45.2 & 77800 & 56.4 & $49, X Y,+X,+2,+8[12] / 46, X Y[8][c p 12]$ \\
\hline 54 & LLC 18 (FS) & M & 70 & 34.6 & 54300 & 56.2 & $48, X Y, t(9 ; 13)(p 24 ; q 13),-10,+12,+19[12] / 46, X Y[8][c p 12]$ \\
\hline
\end{tabular}


ABRUZZO, L. V. Synergy: karyotypes and mutations in CLL. Blood, v. 128, n. 3, p. 319-20, Jul 212016.

AMBROS, V. MicroRNA pathways in flies and worms: growth, death, fat, stress, and timing. Cell, v. 113, n. 6, p. 673-6, Jun 132003.

AMBROS, V.; LEE, R. C. Identification of microRNAs and other tiny noncoding RNAs by CDNA cloning. Methods Mol Biol, v. 265, p. 131-58, 2004.

ARIYOSHI, M.; SCHWABE, J. W. A conserved structural motif reveals the essential transcriptional repression function of Spen proteins and their role in developmental signaling. Genes Dev, v. 17, n. 15, p. 1909-20, Aug 12003.

ATABAKHSH, E. et al. RanBPM has proapoptotic activities that regulate cell death pathways in response to DNA damage. Mol Cancer Res, v. 7, n. 12, p. 1962-72, Dec 2009.

BAKHOUM, S. F.; COMPTON, D. A. Chromosomal instability and cancer: a complex relationship with therapeutic potential. J Clin Invest, v. 122, n. 4, p. 1138-43, Apr 22012.

BARTEL, D. P. MicroRNAs: genomics, biogenesis, mechanism, and function. Cell, v. 116, n. 2, p. 28197, Jan 232004.

BERTOLI, G.; CAVA, C.; CASTIGLIONI, I. MicroRNAs: New Biomarkers for Diagnosis, Prognosis, Therapy Prediction and Therapeutic Tools for Breast Cancer. Theranostics, v. 5, n. 10, p. 1122-43, 2015.

BOMBEN, R. et al. The miR-17 approximately 92 family regulates the response to Toll-like receptor 9 triggering of CLL cells with unmutated IGHV genes. Leukemia, v. 26, n. 7, p. 1584-93, Jul 2012.

BRUGAT, T. et al. Telomere dysfunction-induced foci arise with the onset of telomeric deletions and complex chromosomal aberrations in resistant chronic lymphocytic leukemia cells. Blood, v. 116, n. 2, p. 239-49, Jul 152010.

CALIN, G. A. et al. Frequent deletions and down-regulation of micro- RNA genes miR15 and miR16 at $13 q 14$ in chronic lymphocytic leukemia. Proc Natl Acad Sci U S A, v. 99, n. 24, p. 15524-9, Nov 26 2002.

CALIN, G. A. et al. A MicroRNA signature associated with prognosis and progression in chronic lymphocytic leukemia. N Engl J Med, v. 353, n. 17, p. 1793-801, Oct 272005. 
CALIN, G. A. et al. MicroRNA profiling reveals distinct signatures in B cell chronic lymphocytic leukemias. Proc Natl Acad Sci U S A, v. 101, n. 32, p. 11755-60, Aug 102004.

CARMENA, M.; EARNSHAW, W. C. The cellular geography of aurora kinases. Nat Rev Mol Cell Biol, v. 4, n. 11, p. 842-54, Nov 2003.

CHAN, J. Y. A clinical overview of centrosome amplification in human cancers. Int J Biol Sci, v. 7, n. 8, p. 1122-44, 2011.

CHANG, P. Y. et al. Binding of the MLL PHD3 finger to histone H3K4me3 is required for MLLdependent gene transcription. Journal of Molecular Biology, v. 400, n. 2, p. 137-44, Jul 92010.

CIMINI, D. Detection and correction of merotelic kinetochore orientation by Aurora $B$ and its partners. Cell Cycle, v. 6, n. 13, p. 1558-64, Jul 12007.

. Merotelic kinetochore orientation, aneuploidy, and cancer. Biochim Biophys Acta, v. 1786, n. 1, p. 32-40, Sep 2008.

COLES, A. H.; JONES, S. N. The ING gene family in the regulation of cell growth and tumorigenesis. J Cell Physiol, v. 218, n. 1, p. 45-57, Jan 2009.

CRESPO, M. et al. ZAP-70 expression as a surrogate for immunoglobulin-variable-region mutations in chronic lymphocytic leukemia. N Engl J Med, v. 348, n. 18, p. 1764-75, May 12003.

DAMLE, R. N. et al. Ig $V$ gene mutation status and CD38 expression as novel prognostic indicators in chronic lymphocytic leukemia. Blood, v. 94, n. 6, p. 1840-7, Sep 151999.

DE GROOT, C. O. et al. A Cell Biologist's Field Guide to Aurora Kinase Inhibitors. Front Oncol, v. 5, p. 285, 2015.

DE PAULA CARETA, F. et al. The Aurora A and B kinases are up-regulated in bone marrow-derived chronic lymphocytic leukemia cells and represent potential therapeutic targets. Haematologica, $v$. 97, n. 8, p. 1246-54, Aug 2012.

DEL GIUDICE, I. et al. White blood cell count at diagnosis and immunoglobulin variable region gene mutations are independent predictors of treatment-free survival in young patients with stage $A$ chronic lymphocytic leukemia. Haematologica, v. 96, n. 4, p. 626-30, Apr 2011. 
DOHNER, $\mathrm{H}$. et al. Genomic aberrations and survival in chronic lymphocytic leukemia. N Engl J Med, v. 343, n. 26, p. 1910-6, Dec 282000.

DOYON, Y. et al. ING tumor suppressor proteins are critical regulators of chromatin acetylation required for genome expression and perpetuation. Mol Cell, v. 21, n. 1, p. 51-64, Jan 62006.

EMES, R. D.; PONTING, C. P. A new sequence motif linking lissencephaly, Treacher Collins and oralfacial-digital type 1 syndromes, microtubule dynamics and cell migration. Hum Mol Genet, v. 10, n. 24, p. 2813-20, Nov 152001.

FABBRI, M. et al. Association of a microRNA/TP53 feedback circuitry with pathogenesis and outcome of B-cell chronic lymphocytic leukemia. JAMA, v. 305, n. 1, p. 59-67, Jan 52011.

FANG, J.; VARNEY, M.; STARCZYNOWSKI, D. T. Implication of microRNAs in the pathogenesis of MDS. Curr Pharm Des, v. 18, n. 22, p. 3170-9, 2012.

FILIPOWICZ, W.; BHATTACHARYYA, S. N.; SONENBERG, N. Mechanisms of post-transcriptional regulation by microRNAs: are the answers in sight? Nat Rev Genet, v. 9, n. 2, p. 102-14, Feb 2008.

FISCHER, U. et al. PHF3 expression is frequently reduced in glioma. Cytogenet Cell Genet, v. 94, n. 34, p. 131-6, 2001.

FOA, R. et al. Clinical implications of the molecular genetics of chronic lymphocytic leukemia. Haematologica, v. 98, n. 5, p. 675-85, May 2013.

FRANCIS, O.; HAN, F.; ADAMS, J. C. Molecular Phylogeny of a RING E3 Ubiquitin Ligase, Conserved in Eukaryotic Cells and Dominated by Homologous Components, the Muskelin/RanBPM/CTLH Complex. PLoS One, v. 8, n. 10, p. e75217, 2013.

FUTTERER, A. et al. Dido gene expression alterations are implicated in the induction of hematological myeloid neoplasms. J Clin Invest, v. 115, n. 9, p. 2351-62, Sep 2005.

GARCIA-DOMINGO, D. et al. Death inducer-obliterator 1 triggers apoptosis after nuclear translocation and caspase upregulation. Mol Cell Biol, v. 23, n. 9, p. 3216-25, May 2003.

GATCHALIAN, J. et al. Dido3 PHD modulates cell differentiation and division. Cell Rep, v. 4, n. 1, p. 148-58, Jul 112013. 
GOLDENSON, B.; CRISPINO, J. D. The aurora kinases in cell cycle and leukemia. Oncogene, v. 34, n. 5, p. 537-45, Jan 292015.

GUAN, Z. et al. Aurora-A, a negative prognostic marker, increases migration and decreases radiosensitivity in cancer cells. Cancer Res, v. 67, n. 21, p. 10436-44, Nov 12007.

GUERRERO, A. A. et al. Centromere-localized breaks indicate the generation of DNA damage by the mitotic spindle. Proc Natl Acad Sci U S A, v. 107, n. 9, p. 4159-64, Mar 2010.

GUERRERO, A. A.; MARTINEZ, A. C.; VAN WELY, K. H. Merotelic attachments and non-homologous end joining are the basis of chromosomal instability. Cell Div, v. 5, p. 13, 2010.

GUIEZE, R.; WU, C. J. Genomic and epigenomic heterogeneity in chronic lymphocytic leukemia. Blood, v. 126, n. 4, p. 445-53, Jul 232015.

HALLEK, M. Chronic lymphocytic leukemia: 2015 Update on diagnosis, risk stratification, and treatment. Am J Hematol, v. 90, n. 5, p. 446-60, May 2015.

HAMBLIN, T. J. et al. Unmutated Ig $\mathrm{V}(\mathrm{H})$ genes are associated with a more aggressive form of chronic lymphocytic leukemia. Blood, v. 94, n. 6, p. 1848-54, Sep 151999.

$\mathrm{HE}, \mathrm{S}$. et al. Aurora kinase A induces miR-17-92 cluster through regulation of E2F1 transcription factor. Cell Mol Life Sci, v. 67, n. 12, p. 2069-76, Jun 2010.

HEGYI, K.; MEHES, G. Mitotic failures in cancer: Aurora B kinase and its potential role in the development of aneuploidy. Pathol Oncol Res, v. 18, n. 4, p. 761-9, Oct 2012.

HENSEL, M. et al. High rate of centrosome aberrations and correlation with proliferative activity in patients with untreated B-cell chronic lymphocytic leukemia. Int J Cancer, v. 121, n. 5, p. 978-83, Sep 12007.

HERLING, C. D. et al. Complex karyotypes and KRAS and POT1 mutations impact outcome in CLL after chlorambucil-based chemotherapy or chemoimmunotherapy. Blood, v. 128, n. 3, p. 395-404, Jul 21 2016.

HERLING, M. et al. TCL1 shows a regulated expression pattern in chronic lymphocytic leukemia that correlates with molecular subtypes and proliferative state. Leukemia, v. 20, n. 2, p. 280-5, Feb 2006. 
HIROTA, T. et al. Aurora-A and an interacting activator, the LIM protein Ajuba, are required for mitotic commitment in human cells. Cell, v. 114, n. 5, p. 585-98, Sep 52003.

INAMDAR, K. V. et al. Aurora-A kinase nuclear expression in chronic lymphocytic leukemia. Mod Pathol, v. 21, n. 12, p. 1428-35, Dec 2008.

JAHRSDORFER, B.; WEINER, G. J. Short telomeres in B-CLL: the chicken or the egg? Blood, v. 111, $\mathrm{n}$. 12, p. 5756; author reply 5756-7, Jun 152008.

JIN, H. Y. et al. MicroRNA-17 92 plays a causative role in lymphomagenesis by coordinating multiple oncogenic pathways. EMBO J, v. 32, n. 17, p. 2377-91, Aug 282013.

JULIUSSON, G. et al. Prognostic subgroups in B-cell chronic lymphocytic leukemia defined by specific chromosomal abnormalities. N Engl J Med, v. 323, n. 11, p. 720-4, Sep 131990.

KATSHA, A. et al. Aurora kinase A in gastrointestinal cancers: time to target. Mol Cancer, v. 14, p. 106, 2015.

KINKELIN, K. et al. Structures of RNA polymerase II complexes with Bye1, a chromatin-binding PHF3/DIDO homologue. Proc Natl Acad Sci U S A, v. 110, n. 38, p. 15277-82, Sep 172013.

KOBAYASHI, N. et al. RanBPM, Muskelin, p48EMLP, p44CTLH, and the armadillo-repeat proteins ARMC8alpha and ARMC8beta are components of the CTLH complex. Gene, v. 396, n. 2, p. 236-47, Jul 152007.

KOLLAREDDY, M. et al. Aurora kinases: structure, functions and their association with cancer. Biomed Pap Med Fac Univ Palacky Olomouc Czech Repub, v. 152, n. 1, p. 27-33, Jun 2008.

LEE, D. F. et al. Regulation of embryonic and induced pluripotency by aurora kinase-p53 signaling. Cell Stem Cell, v. 11, n. 2, p. 179-94, Aug 32012.

LEE, Y. et al. The nuclear RNase III Drosha initiates microRNA processing. Nature, v. 425, n. 6956, p. 415-9, Sep 252003.

LEE, Y. et al. MicroRNA maturation: stepwise processing and subcellular localization. EMBO J, v. 21, n. 17, p. 4663-70, Sep 22002.

LI, Z.; RANA, T. M. A kinase inhibitor screen identifies small-molecule enhancers of reprogramming and iPS cell generation. Nat Commun, v. 3, p. 1085, 2012. 
LIN, T. T. et al. Telomere dysfunction and fusion during the progression of chronic lymphocytic leukemia: evidence for a telomere crisis. Blood, v. 116, n. 11, p. 1899-907, Sep 162010.

LIN, T. T. et al. Telomere dysfunction accurately predicts clinical outcome in chronic lymphocytic leukaemia, even in patients with early stage disease. Br J Haematol, v. 167, n. 2, p. 214-23, Oct 2014.

LUCENA-ARAUJO, A. R. et al. High expression of AURKA and AURKB is associated with unfavorable cytogenetic abnormalities and high white blood cell count in patients with acute myeloid leukemia. Leuk Res, v. 35, n. 2, p. 260-4, Feb 2011.

LUND, E. et al. Nuclear export of microRNA precursors. Science, v. 303, n. 5654, p. 95-8, Jan 22004.

MARTINEZ, A. C.; VAN WELY, K. H. Centromere fission, not telomere erosion, triggers chromosomal instability in human carcinomas. Carcinogenesis, v. 32, n. 6, p. 796-803, Jun 2011.

MARUMOTO, T. et al. Aurora-A kinase maintains the fidelity of early and late mitotic events in HeLa cells. J Biol Chem, v. 278, n. 51, p. 51786-95, Dec 192003.

MAYR, C. et al. Chromosomal translocations are associated with poor prognosis in chronic lymphocytic leukemia. Blood, v. 107, n. 2, p. 742-51, Jan 152006.

MEDINA, P. P.; SLACK, F. J. microRNAs and cancer: an overview. Cell Cycle, v. 7, n. 16, p. 2485-92, Aug 152008.

MEHRA, R. et al. Aurora kinases in head and neck cancer. Lancet Oncol, v. 14, n. 10, p. e425-35, Sep 2013.

MELLOR, J. It takes a PHD to read the histone code. Cell, v. 126, n. 1, p. 22-4, Jul 142006.

MOGILYANSKY, E.; RIGOUTSOS, I. The miR-17/92 cluster: a comprehensive update on its genomics, genetics, functions and increasingly important and numerous roles in health and disease. Cell Death Differ, v. 20, n. 12, p. 1603-14, Dec 2013.

MURAKI, K. et al. Mechanisms of telomere loss and their consequences for chromosome instability. Front Oncol, v. 2, p. 135, 2012.

MURNANE, J. P. Telomere dysfunction and chromosome instability. Mutat Res, v. 730, n. 1-2, p. 2836, Feb 12012. 
MUTHUSAMY, N. et al. Enhanced detection of chromosomal abnormalities in chronic lymphocytic leukemia by conventional cytogenetics using CpG oligonucleotide in combination with pokeweed mitogen and phorbol myristate acetate. Cancer Genet, v. 204, n. 2, p. 77-83, Feb 2011.

NIKONOVA, A. S. et al. Aurora A kinase (AURKA) in normal and pathological cell division. Cell Mol Life Sci, v. 70, n. 4, p. 661-87, Feb 2013.

O'DONNELL, K. A. et al. c-Myc-regulated microRNAs modulate E2F1 expression. Nature, v. 435, n. 7043, p. 839-43, Jun 92005.

OTTAGGIO, L. et al. The presence of high-risk chromosome aberrations in chronic lymphocytic leukaemia does not correlate with centrosome aberrations. Hematol Oncol, v. 26, n. 1, p. 39-42, Mar 2008.

OUCHI, M. et al. BRCA1 phosphorylation by Aurora-A in the regulation of G2 to M transition. J Biol Chem, v. 279, n. 19, p. 19643-8, May 72004.

PEKARSKY, Y. et al. Tcl1 expression in chronic lymphocytic leukemia is regulated by miR-29 and miR181. Cancer Res, v. 66, n. 24, p. 11590-3, Dec 152006.

PENA, P. V. et al. Molecular mechanism of histone H3K4me3 recognition by plant homeodomain of ING2. Nature, v. 442, n. 7098, p. 100-3, Jul 62006.

PFAFFL, M. W. A new mathematical model for relative quantification in real-time RT-PCR. Nucleic Acids Res, v. 29, n. 9, p. e45, May 12001.

PICHE, B.; LI, G. Inhibitor of growth tumor suppressors in cancer progression. Cell Mol Life Sci, v. 67, n. 12, p. 1987-99, Jun 2010.

PINSKAYA, M. et al. PHD and TFIIS-Like domains of the Bye1 transcription factor determine its multivalent genomic distribution. PLoS One, v. 9, n. 7, p. e102464, 2014.

PRIETO, I. et al. Synaptonemal complex assembly and H3K4Me3 demethylation determine DIDO3 localization in meiosis. Chromosoma, v. 118, n. 5, p. 617-32, Oct 2009.

PUENTE, X. S. et al. Whole-genome sequencing identifies recurrent mutations in chronic lymphocytic leukaemia. Nature, v. 475, n. 7354, p. 101-5, Jul 72011. 
PUVEREL, S. et al. RanBPM is essential for mouse spermatogenesis and oogenesis. Development, $v$. 138, n. 12, p. 2511-21, Jun 2011.

RAMSAY, A. J. et al. POT1 mutations cause telomere dysfunction in chronic lymphocytic leukemia. Nat Genet, v. 45, n. 5, p. 526-30, May 2013.

RICKE, R. M.; VAN DEURSEN, J. M. Correction of microtubule-kinetochore attachment errors: mechanisms and role in tumor suppression. Semin Cell Dev Biol, v. 22, n. 6, p. 559-65, Aug 2011.

ROJAS, A. M. et al. Death inducer obliterator protein 1 in the context of DNA regulation. Sequence analyses of distant homologues point to a novel functional role. FEBS J, v. 272, n. 14, p. 3505-11, Jul 2005.

ROOS, G. et al. Short telomeres are associated with genetic complexity, high-risk genomic aberrations, and short survival in chronic lymphocytic leukemia. Blood, v. 111, n. 4, p. 2246-52, Feb 152008.

SANCHEZ-PULIDO, L. et al. SPOC: a widely distributed domain associated with cancer, apoptosis and transcription. BMC Bioinformatics, v. 5, p. 91, Jul 72004.

SANDHU, S. K. et al. B-cell malignancies in microRNA Emu-miR-17 92 transgenic mice. Proc Natl Acad Sci U S A, v. 110, n. 45, p. 18208-13, Nov 52013.

SANTANAM, $U$. et al. Chronic lymphocytic leukemia modeled in mouse by targeted miR-29 expression. Proc Natl Acad Sci U S A, v. 107, n. 27, p. 12210-5, Jul 62010.

SANTIVERI, C. M. et al. NMR structure note: PHD domain from death inducer obliterator protein and its interaction with H3K4me3. J Biomol NMR, v. 56, n. 2, p. 183-90, Jun 2013.

SATINOVER, D. L.; BRAUTIGAN, D. L.; STUKENBERG, P. T. Aurora-A kinase and inhibitor-2 regulate the cyclin threshold for mitotic entry in Xenopus early embryonic cell cycles. Cell Cycle, v. 5, n. 19, p. 2268-74, Oct 2006.

SCOTT, B. L.; DEEG, H. J. Myelodysplastic syndromes. Annu Rev Med, v. 61, p. 345-58, 2010.

$\mathrm{SHI}, \mathrm{X}$. et al. ING2 PHD domain links histone H3 lysine 4 methylation to active gene repression. Nature, v. 442, n. 7098, p. 96-9, Jul 62006. 
SINGH, S. K. et al. MicroRNAs--micro in size but macro in function. FEBS J, v. 275, n. 20, p. 4929-44, Oct 2008.

SYLVESTRE, Y. et al. An E2F/miR-20a autoregulatory feedback loop. J Biol Chem, v. 282, n. 4, p. 213543, Jan 262007.

TAYLOR, S. S.; SCOTT, M. I.; HOLLAND, A. J. The spindle checkpoint: a quality control mechanism which ensures accurate chromosome segregation. Chromosome Res, v. 12, n. 6, p. 599-616, 2004.

TENNEY, K.; SHILATIFARD, A. A COMPASS in the voyage of defining the role of trithorax/MLLcontaining complexes: linking leukemogensis to covalent modifications of chromatin. J Cell Biochem, v. 95, n. 3, p. 429-36, Jun 12005.

THOMPSON, P. A. et al. Complex karyotype is a stronger predictor than del(17p) for an inferior outcome in relapsed or refractory chronic lymphocytic leukemia patients treated with ibrutinibbased regimens. Cancer, v. 121, n. 20, p. 3612-21, Oct 152015.

TRACHANA, V. et al. Dido disruption leads to centrosome amplification and mitotic checkpoint defects compromising chromosome stability. Proc Natl Acad Sci U S A, v. 104, n. 8, p. 2691-6, Feb 20 2007.

TSENG, Y. S. et al. Aurora-A overexpression enhances cell-aggregation of Ha-ras transformants through the MEK/ERK signaling pathway. BMC Cancer, v. 9, p. 435, 2009.

TUSELL, L. et al. The number of dysfunctional telomeres in a cell: one amplifies; more than one translocate. Cytogenet Genome Res, v. 122, n. 3-4, p. 315-25, 2008.

UMEDA, M.; NISHITANI, H.; NISHIMOTO, T. A novel nuclear protein, Twa1, and Muskelin comprise a complex with RanBPM. Gene, v. 303, p. 47-54, Jan 162003.

VALENT, P. et al. Standards and impact of hematopathology in myelodysplastic syndromes (MDS). Oncotarget, v. 1, n. 7, p. 483-96, Nov 2010.

VAZQUEZ-NOVELLE, M. D. et al. The 'anaphase problem': how to disable the mitotic checkpoint when sisters split. Biochem Soc Trans, v. 38, n. 6, p. 1660-6, Dec 2010.

WANG, Y. et al. Aurora-A: a potential DNA repair modulator. Tumour Biol, v. 35, n. 4, p. 2831-6, Apr 2014. 
WILLIMOTT, S.; WAGNER, S. D. Stromal cells and CD40 ligand (CD154) alter the miRNome and induce miRNA clusters including, miR-125b/miR-99a/let-7c and miR-17-92 in chronic lymphocytic leukaemia. Leukemia, v. 26, n. 5, p. 1113-6, May 2012.

YANG, G. et al. RAS promotes tumorigenesis through genomic instability induced by imbalanced expression of Aurora-A and BRCA2 in midbody during cytokinesis. Int J Cancer, v. 133, n. 2, p. 275-85, Jul 152013.

YANG, J. et al. Bcr-Abl activates AURKA and AURKB in chronic myeloid leukemia cells via AKT signaling. Int J Cancer, v. 134, n. 5, p. 1183-94, Mar 12014.

YU, H. Regulation of APC-Cdc20 by the spindle checkpoint. Curr Opin Cell Biol, v. 14, n. 6, p. 706-14, Dec 2002.

ZANETTE, D. L. et al. miRNA expression profiles in chronic lymphocytic and acute lymphocytic leukemia. Braz J Med Biol Res, v. 40, n. 11, p. 1435-40, Nov 2007.

ZHANG, S. et al. Targeting chronic lymphocytic leukemia cells with a humanized monoclonal antibody specific for CD44. Proc Natl Acad Sci U S A, v. 110, n. 15, p. 6127-32, Apr 92013. 